\title{
SEVERIDADE DE Phaeosphaeria maydis E RENDIMENTO DE GRÃOS DE MILHO (Zea mays L.) EM DIFERENTES AMBIENTES E DOSES DE NITROGÊNIO
}

\section{FLÁVIO MURILO PEREIRA DA COSTA}

Dissertação apresentada à Escola Superior de Agricultura "Luiz de Queiroz", Universidade de São Paulo, para obtenção do título de Mestre em Agronomia, Área de Concentração: Fitotecnia.

\section{PIRACICABA}

Estado de São Paulo - Brasil

Novembro - 2001 


\title{
SEVERIDADE DE Phaeosphaeria maydis E RENDIMENTO DE GRÃOS DE MILHO (Zea mays L.) EM DIFERENTES AMBIENTES E DOSES DE NITROGÊNIO
}

\author{
FLÁVIO MURILO PEREIRA DA COSTA \\ Engenheiro Agrônomo
}

Orientador: Prof. Dr. DURVAL DOURADO-NETO

\begin{abstract}
Dissertação apresentada à Escola Superior de Agricultura "Luiz de Queiroz", Universidade de São Paulo, para obtenção do título de Mestre em Agronomia, Área de Concentração: Fitotecnia.
\end{abstract}

PIRACICABA

Estado de São Paulo - Brasil

Novembro -2001 
Dados Internacionais de Catalogação na Publicação (CIP)
DIVISÃO DE BIBLIOTECA E DOCUMENTAÇÃO - ESALQ/USP

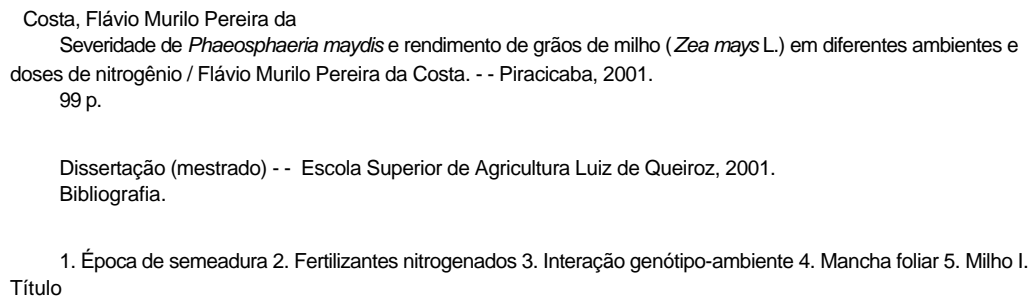

CDD 633.15

\section{"Permitida a cópia total ou parcial deste documento, desde que citada a fonte - $\mathrm{O}$ autor"}


Esse trabalho é dedicado ao futuro da agricultura brasileira, cheia de carências e necessidades urgentes.

Em especial dedico,

à minha esposa Patrícia, pelo respeito e estímulo à realização do Curso.

Ofereşo,

ao casal amigo Luciano/Nilce, pela grande força em Piracicaba.

ao meu orientador, Prof. Durval, por sua preocupada dedicaşão ao ensino.

ao meu Pai e à minha Mãe, com muito carinho: irmãos, irmãs e pimpolhos, que tanto estimo. 


\section{AGRADECIMENTOS}

À CAPES/DS, Ministério da Educação, pela concessão da Bolsa de Estudos.

Ao Prof. Dr. Durval Dourado-Neto, pelo inestimável companheirismo e excelente orientação.

Ao Prof. Dr. Antônio Luiz Fancelli, pelo auxílio na idealização do projeto.

Ao Prof. Dr. Ricardo de Oliveira Ferraz, pelo empréstimo dos instrumentos e aparelhos utilizados nas avaliações.

Ao Prof. Dr. José Branco de Miranda Filho, pela cessão e utilização das dependências do Departamento de Genética e, acima de tudo, à grande amizade.

Ao Departamento de Genética, pela concessão da área experimental.

Aos Eng. Agr. Cláudio Segatelli e Edson Teramoto, pela valiosa colaboração no trabalho e à amizade.

Às pós-graduandas do Departamento de Fitopatologia, Kátia e Maria Teresa, pela grande colaboração nas avaliações de doença.

À Eng. Agr. Aline de Holanda Nunes Maia, pela orientação no delineamento experimental.

À Bibliotecária Eliana Maria Garcia, pela revisão do item Referências Bibliográficas e da formatação geral do texto.

Aos funcionários e colegas do Departamento de Produção Vegetal da Escola Superior de Agricultura "Luiz de Queiroz", da Universidade de São Paulo, em Piracicaba, pelo troca de experiências e apoio.

Em especial, ao Sr. Jair Vitorio Arthur, pela amizade e valiosa colaboração no trabalho.

A todos aqueles que, embora não citados aqui, sabem que contribuíram em alguma etapa da minha vida. 


\section{SUMÁRIO}

Página

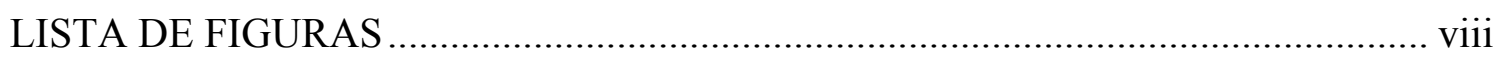

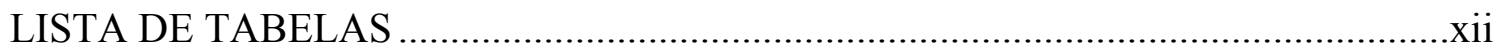

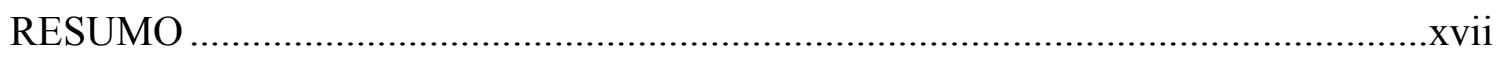

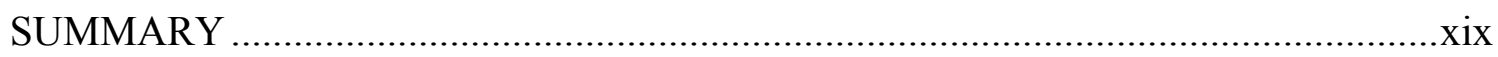

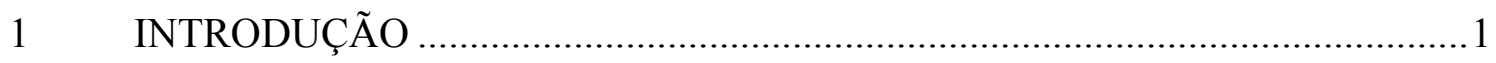

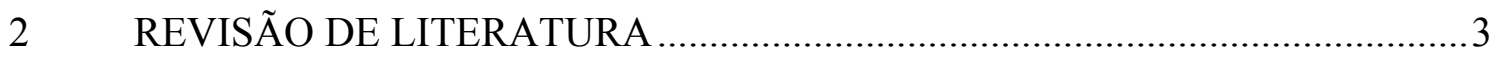

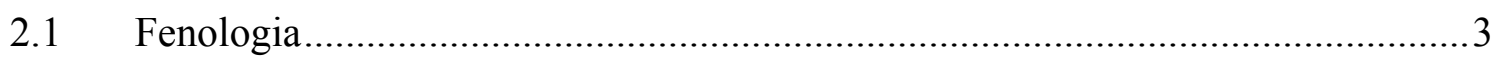

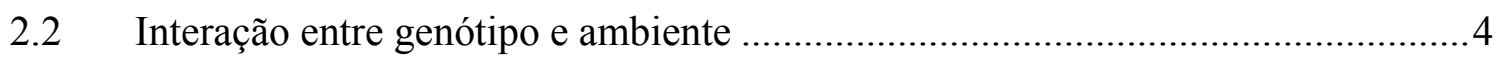

$2.3 \quad$ Estresse do ambiente ...................................................................................

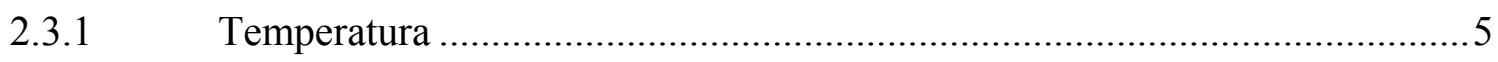

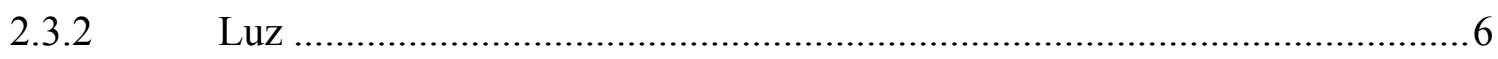

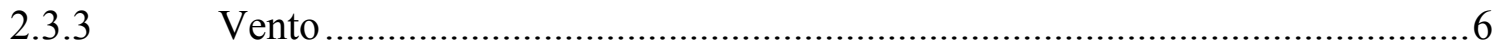

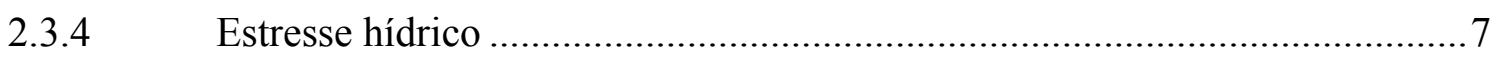

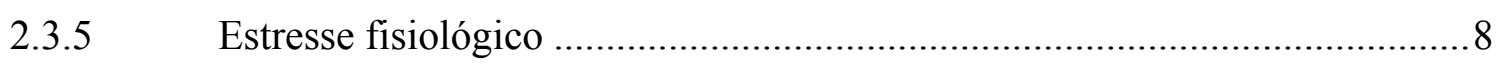

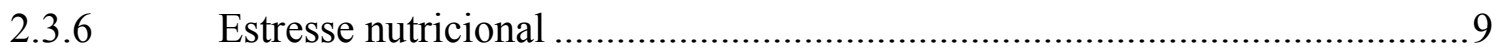

2.4 Adubação nitrogenada................................................................................... 10

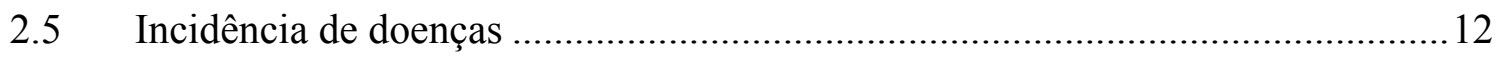

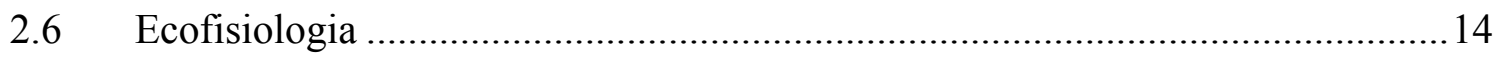

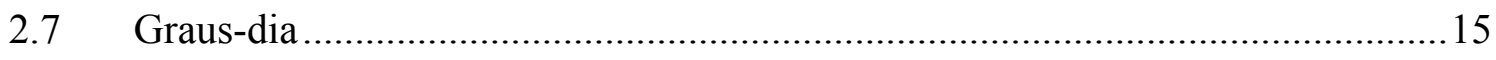


3 MATERIAL E MÉTODOS

3.1 Caracterização dos locais dos experimentos ....................................................... 17

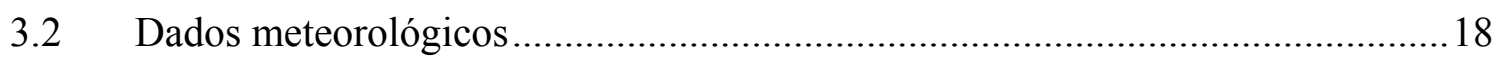

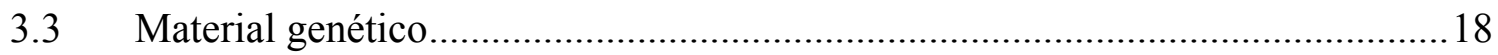

3.4 Delineamento experimental e análise estatística................................................. 18

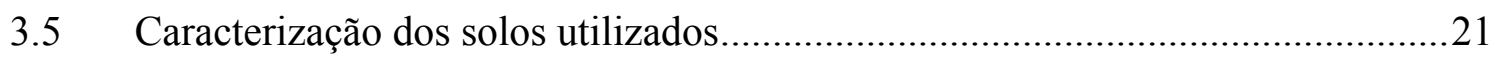

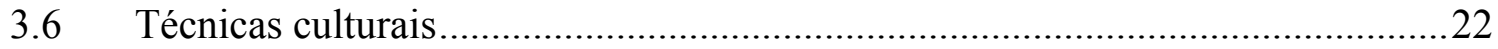

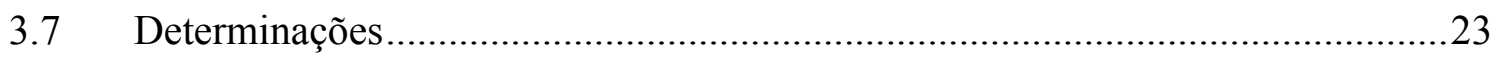

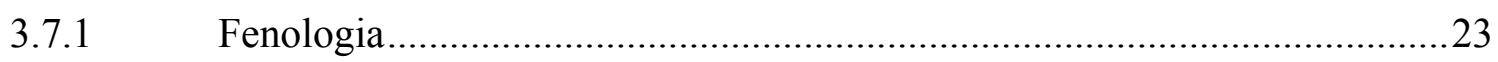

3.7.2 Graus-dia e desenvolvimento relativo da cultura.........................................23

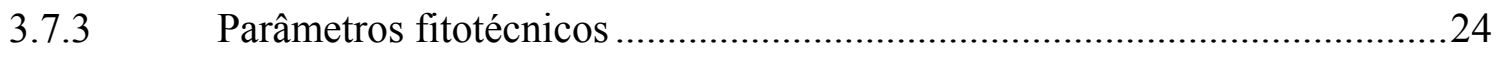

3.7.3.1 Procedimento de determinação do índice de área foliar .............................24

3.7.3.2 Procedimentos de determinação dos componentes de produção ...............25

3.7.3.3 Procedimento de determinação do teor de clorofila total..........................26

3.7.4 Procedimento de determinação do índice de severidade da doença causada por Phaeosphaeria maydis ......................................................................................26

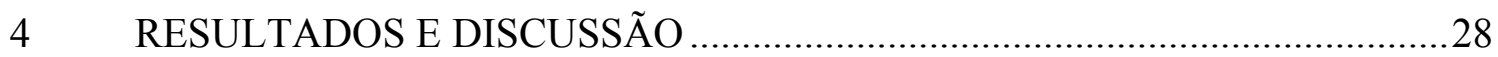

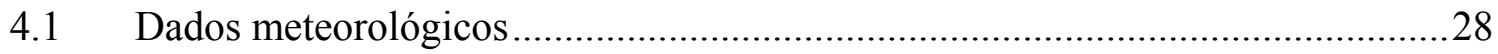

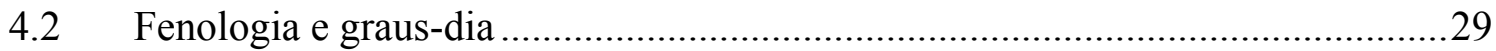

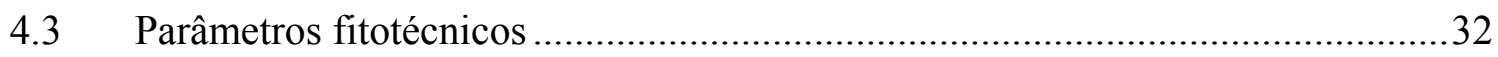

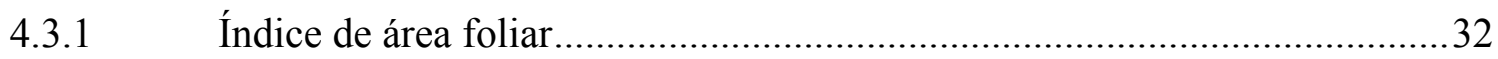

4.3.2 Componentes de produção ……………….............................................

4.3.2.1 Rendimento de grãos de milho...........................................................

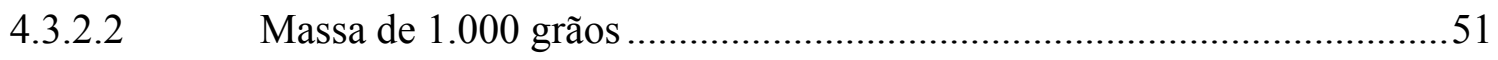

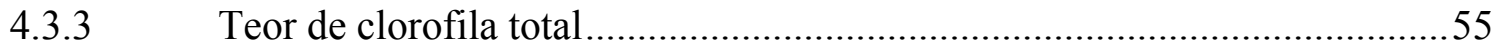

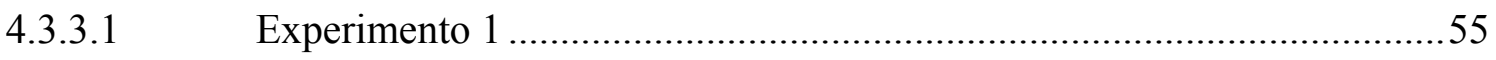

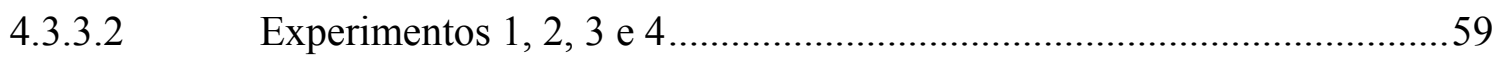

4.4 Incidência e severidade de P. maydis................................................................65

4.5 Rendimento de grãos e índice de severidade por genótipo ………………….......69 


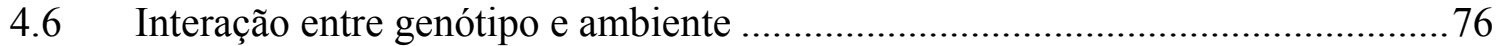

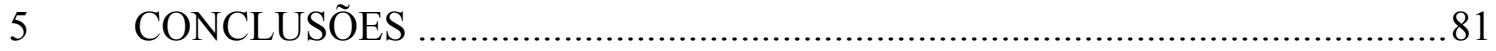

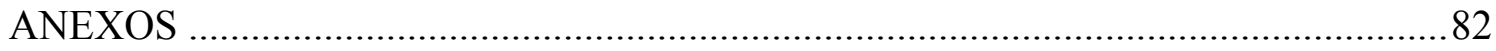

REFERÊNCIAS BIBLIOGRÁFICAS .............................................................. 93 


\section{LISTA DE FIGURAS}

Página

1 Ciclo da cultura: estádios de crescimento e desenvolvimento referentes fase

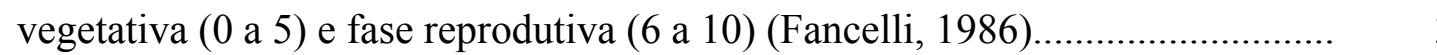

2 Representação esquemática da área experimental: (A) os três blocos, (B) as 25 parcelas experimentais em um bloco, e (C) a parcela experimental indicando a área útil para determinação do rendimento de grãos e o espaçamento " $e$ " $(0,75 \mathrm{~m}$ para o local 1 e $0,80 \mathrm{~m}$ para o local 2$)$

3 Rendimento de grãos de milho ( $\mathrm{R}, \mathrm{kg} / \mathrm{ha})$ em função de doses crescentes de nitrogênio. Experimento 1. Data de semeadura: 11 de setembro de 2000

4 Rendimento de grãos de milho ( $\mathrm{R}, \mathrm{kg} / \mathrm{ha}$ ) em função de doses crescentes de nitrogênio. Experimento 2. Data de semeadura: 29 de novembro de 2000...........

5 Rendimento de grãos de milho ( $\mathrm{R}, \mathrm{kg} / \mathrm{ha})$ em função de doses crescentes de nitrogênio. Experimento 3. Data de semeadura: 27 de dezembro de 2000............

6 Rendimento de grãos de milho ( $\mathrm{R}, \mathrm{kg} / \mathrm{ha})$ em função de doses crescentes de nitrogênio. Experimento 4. Data de semeadura: 22 de fevereiro de $2001 \ldots \ldots \ldots \ldots . . . .50$

7 Massa de 1000 grãos (g) em função de doses crescentes de nitrogênio.

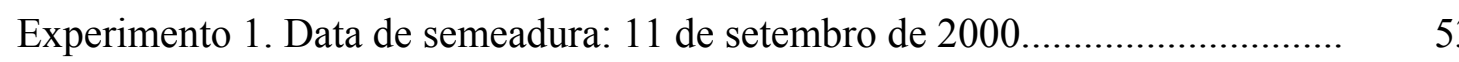

8 Massa de 1000 grãos (g) em função de doses crescentes de nitrogênio.

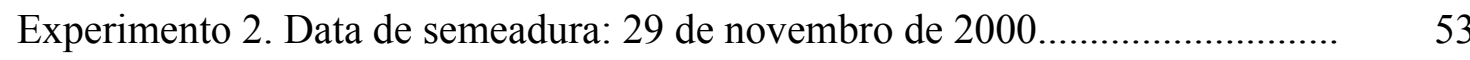

9 Massa de 1000 grãos (g) em função de doses crescentes de nitrogênio. Experimento 3. Data de semeadura: 27 de dezembro de 2000 ............................ 
10 - Massa de 1000 grãos (g) em função de doses crescentes de nitrogênio. Experimento 4. Data de semeadura: 22 de fevereiro de 2001.

11 - Variação temporal (valores observados em função do número de dias após a emergência, DAE) da leitura do clorofilômetro (Lc, leitura SPAD) na folha de milho para as diferentes doses utilizadas de nitrogênio $(0,60,120,180$ e 240 $\mathrm{kg} / \mathrm{ha})$.

12 - Modelo descritor (Tabela 1) da variação temporal (Dias Após a Emergência, DAE) da leitura do clorofilômetro (Lc, leitura SPAD) de milho em função da adubação nitrogenada ( $\mathrm{N}, \mathrm{kg} / \mathrm{ha})$.

13 - Variação temporal da temperatura média do ar durante o ciclo da cultura de milho (dias após a emergência - DAE - e desenvolvimento relativo da cultura Dr) (experimento 1).

14 - Relação entre leitura SPAD (Clorofilômetro, Lc), doses crescentes de nitrogênio, índice de severidade e rendimento de grãos de milho (Experimento $1)$.

15 - Relação entre leitura SPAD (Clorofilômetro, Lc), doses crescentes de nitrogênio, índice de severidade e rendimento de grãos de milho (Experimento 2).

16 - Relação entre leitura SPAD (Clorofilômetro, Lc), doses crescentes de nitrogênio, índice de severidade e rendimento de grãos de milho (Experimento $3)$.

17 - Relação entre leitura SPAD (Clorofilômetro, Lc), doses crescentes de nitrogênio, índice de severidade e rendimento de grãos de milho (Experimento $4)$.

18 - Índice de severidade de $P$. maydis (IS) em função de doses crescentes de nitrogênio. Experimento 1 (avaliação aos 98 dias após a emergência). 
19 - Índice de severidade de P. maydis (IS) em função de doses crescentes de nitrogênio. Experimento 2 (avaliação aos 100 dias após a emergência).

20 - Índice de severidade de $P$. maydis (IS) em função de doses crescentes de nitrogênio. Experimento 3 (avaliação aos 88 dias após a emergência).

21 - Índice de severidade de $P$. maydis (IS) em função de doses crescentes de nitrogênio. Experimento 4 (avaliação aos 90 dias após a emergência).

22 - Rendimento de grãos (R, kg/ha) e índice de severidade de P. maydis (IS) referentes ao genótipo 1 (P-30F45) em função do efeito das diferentes épocas

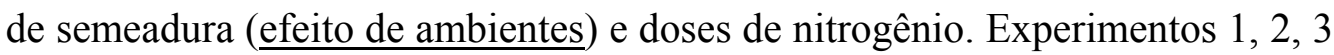
e 4 .

23 - Rendimento de grãos (R, kg/ha) e índice de severidade de P. maydis (IS) referentes ao genótipo 1 (P-30F45) em função de doses crescentes de nitrogênio, nos quatro experimentos (efeito de dose).

24 - Rendimento de grãos ( $\mathrm{R}, \mathrm{kg} / \mathrm{ha}$ ) e índice de severidade de $P$. maydis (IS) referentes ao genótipo 2 (C333-B) em função do efeito das diferentes épocas

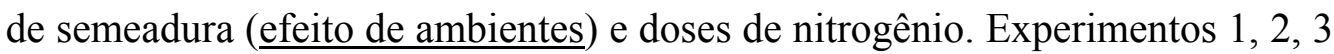
e 4.

25 - Rendimento de grãos (R, kg/ha) e índice de severidade de P. maydis (IS) referentes ao genótipo 2 (C333-B) em função de doses crescentes de nitrogênio nos quatro experimentos (efeito da dose).

26 - Rendimento de grãos (R, kg/ha) e índice de severidade de $P$. maydis (IS) referentes ao genótipo 3 (P-30K75) em função do efeito das diferentes épocas de semeadura (efeito de ambientes) e doses de nitrogênio. Experimentos 1, 2, 3 e 4 .

27 - Rendimento de grãos (R, kg/ha) e índice de severidade de P. maydis (IS) referentes ao genótipo 3 (P-30K75) em função de doses crescentes de nitrogênio nos quatro experimentos (efeito da dose). 
28 - Rendimento de grãos (R, kg/ha) e índice de severidade de $P$. maydis (IS) referentes ao genótipo 4 (CO-9560) em função do efeito das diferentes épocas de semeadura (efeito de ambientes) e doses de nitrogênio. Experimentos 1, 2, 3 e 4 .

29 - Rendimento de grãos (R, kg/ha) e índice de severidade de P. maydis (IS) referentes ao genótipo 4 (CO-9560) em função de doses crescentes de nitrogênio nos quatro experimentos (efeito da dose).

30 - Rendimento de grãos (R, kg/ha) e índice de severidade de P. maydis (IS) referentes ao genótipo 5 (C-909) em função do efeito das diferentes épocas de semeadura (efeito de ambientes) e doses de nitrogênio. Experimentos 1, 2, 3 e 4.

31 - Rendimento de grãos (R, kg/ha) e índice de severidade de P. maydis (IS) referentes ao genótipo 5 (C-909) em função de doses crescentes de nitrogênio nos quatro experimentos (efeito da dose). 


\section{LISTA DE TABELAS}

Página

32 Descrição sucinta dos estádios fenológicos da cultura de milho (Fancelli \& Dourado-Neto, 2000)

33 Caracterização dos locais dos quatro experimentos conduzidos para realização deste trabalho e suas respectivas datas de semeadura e de colheita.

34 Descrição sucinta dos cinco genótipos utilizados nos quatro experimentos (informação fornecida pelas empresas produtoras)

35 Causas de variação e graus de liberdade na análise de variância utilizada...........

36 Resultado das análises químicas de solo das duas localidades estudadas.............

37 Descrição sumária das parâmetros fitotécnicos determinados nos experimentos em função do número de avaliações $(\mathrm{N})$ nos diferentes estádios fenológicos......

38 Correspondência do número de dias após a emergência com a fenologia referente aos cinco genótipos, nos quatro experimentos (E), especificando a data de semeadura, número de folhas $(1 F$ a $12 F)$, número de dias após a emergência (DAE) para o florescimento e graus-dia $\left(G D_{f l},{ }^{\circ} \mathrm{C}\right.$. dia $)$.....................

39 Número de dias após a emergência (DAE) para o florescimento geral e para o ponto de maturidade fisiológica referente aos cinco genótipos nos quatro experimentos (média de 3 repetições)

40 Índice área foliar (IAF, $\mathrm{m}^{2} / \mathrm{m}^{2}$ ) (média de 3 repetições) avaliado em três diferentes épocas (experimento 1, data de semeadura: 11 de setembro de 2000, população: 70.000 plantas/ha). 
41 Resumo da análise individual das médias de doses de nitrogênio para índice de área foliar $\left(\mathrm{m}^{2} / \mathrm{m}^{2}\right)$ (experimento 1 , população de 70.000 plantas/ha), em três épocas de avaliação, com teste $\mathrm{F}$ para genótipos dentro de doses (média de 3 repetições).

42 Resumo da análise de variância referente ao índice de área foliar $\left(\mathrm{m}^{2} / \mathrm{m}^{2}\right)$ (experimento 1, população de 70.000 plantas/ha) em três épocas de avaliação...

43 Índice área foliar (IAF, $\mathrm{m}^{2} / \mathrm{m}^{2}$ ) (média de 3 repetições) avaliado em três diferentes épocas (experimento 2, data de semeadura: 29 de novembro de 2000, população: 70.000 plantas/ha).

44 Resumo da análise individual das médias de doses de nitrogênio para índice de área foliar $\left(\mathrm{m}^{2} / \mathrm{m}^{2}\right)$ (experimento 2, população de 70.000 plantas $/ \mathrm{ha}$ ), em três épocas de avaliação, com teste F para genótipos dentro de doses (média de 3 repetições)

45 Resumo da análise de variância referente ao índice de área foliar $\left(\mathrm{m}^{2} / \mathrm{m}^{2}\right)$ (experimento 2, população de 70.000 plantas/ha) em três épocas de avaliação.

46 Índice área foliar (IAF, $\mathrm{m}^{2} / \mathrm{m}^{2}$ ) (média de 3 repetições) avaliado em cinco diferentes épocas (experimento 3, data de semeadura: 27 de dezembro de 2000, população: 65.625 plantas/ha).

47 Resumo da análise individual das médias de doses de nitrogênio para índice de área foliar $\left(\mathrm{m}^{2} / \mathrm{m}^{2}\right)$ (experimento 3 , população de 65.625 plantas $/$ ha), em cinco épocas de avaliação, com teste F para genótipos dentro de doses (média de 3 repetições)

48 Resumo da análise de variância referente ao índice de área foliar $\left(\mathrm{m}^{2} / \mathrm{m}^{2}\right)$ (experimento 3, população de 65.625 plantas/ha) em três épocas de avaliação.

49 Índice área foliar (IAF, $\mathrm{m}^{2} / \mathrm{m}^{2}$ ) (média de 3 repetições) avaliado em quatro diferentes épocas (experimento 4, data de semeadura: 22 de fevereiro de 2001, população: 65.625 plantas/ha). 
50 Resumo da análise individual das médias de doses de nitrogênio para índice de área foliar $\left(\mathrm{m}^{2} / \mathrm{m}^{2}\right)$ (experimento 4 , população de 65.625 plantas/ha), em quatro épocas de avaliação, com teste $\mathrm{F}$ para genótipos dentro de doses (média de 3

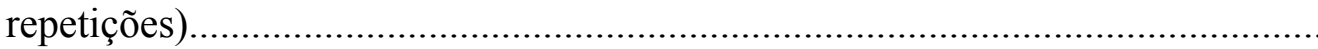

51 Resumo da análise de variância referente ao índice de área foliar $\left(\mathrm{m}^{2} / \mathrm{m}^{2}\right)$ (experimento 4, população de 65.625 plantas/ha) em três épocas de avaliação...

52 Resumo dos diferentes componentes de produção avaliados no experimento 1 para os cinco genótipos utilizados e respectivos efeitos da análise de regressão em função de doses de nitrogênio.

53 Resumo dos diferentes componentes de produção avaliados no experimento 2 para os cinco genótipos utilizados e respectivos efeitos da análise de regressão em função de doses de nitrogênio.

54 Resumo dos diferentes componentes de produção avaliados no experimento 3 para os cinco genótipos utilizados e respectivos efeitos da análise de regressão em função de doses de nitrogênio.

55 Resumo dos diferentes componentes de produção avaliados no experimento 4 para os cinco genótipos utilizados e respectivos efeitos da análise de regressão em função de doses de nitrogênio.

56 Rendimento médio de grãos ( $\mathrm{kg} / \mathrm{ha})$, para cada genótipo em cada dose de nitrogênio, nos quatro experimentos (média de 3 repetições)..............................

57 Modelo descritor da variação temporal (Dr) do teor clorofila na folha (Tcf, $\mu \mathrm{g} / \mathrm{mg})$ de milho para as diferentes doses utilizadas de nitrogênio ( $\mathrm{N}, \mathrm{kg} / \mathrm{ha})$.

58 Resultado das análises individuais nos quatro ambientes, teste de homogeneidade e análise conjunta da variância de dados de rendimento de grãos (kg/ha) dos cinco genótipos em combinação com doses de nitrogênio....... 
59 Rendimento médio ( $\mathrm{kg} / \mathrm{ha}$ ) e estimativa dos efeitos principais dos genótipos dentro de dose de nitrogênio dos quatro diferentes ambientes (experimentos 1,

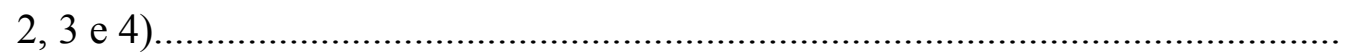

60 Estimativas dos efeitos da interação combinada de genótipos e doses de nitrogênio $\left(T \hat{a}_{t a}\right)$ com os quatro ambientes relativas aos dados da Tabela $28 . . .$.

61 Valores mensais de temperatura $\left({ }^{\circ} \mathrm{C}\right)$ do ar (média das máximas e das mínimas e média geral), umidade relativa (\%) do ar (média das máximas e das mínimas e média geral), radiação global média $\left(\mathrm{MJ} / \mathrm{m}^{2}\right.$.dia) e chuva ( $\left.\mathrm{mm} / \mathrm{mês}\right)$, nos

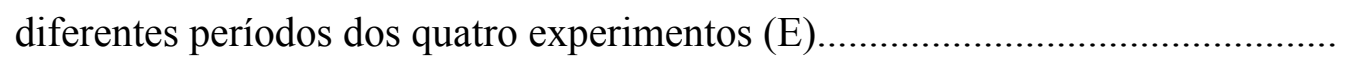

62 Análise de variância referente aos parâmetros: índice de área foliar (IAF, $\left.\mathrm{m}^{2} / \mathrm{m}^{2}\right)$ no florescimento; massa de 1000 grãos $\left(\mathrm{M}_{1000}, \mathrm{~g}\right)$; leitura do clorofilômetro (leitura SPAD, Lc) no estádio fenológico 8; rendimento de grãos (R, kg/ha) e índice de severidade (IS) avaliado entre os estágios fenológicos 8 e 9 .

63 Estimativas dos coeficientes da regressão polinomial: intercepto (a), linear (b) e quadrática (c) para os diferentes genótipos (efeito de doses) para os parâmetros rendimento $(\mathrm{R}, \mathrm{kg} / \mathrm{ha})$, massa de 1000 grãos $\left(\mathrm{M}_{1000}, \mathrm{~g}\right)$, leitura do clorofilômetro (leitura SPAD, Lc), índice de área foliar (IAF, $\mathrm{m}^{2} / \mathrm{m}^{2}$ ) no florescimento e índice de severidade (IS) à P. maydis. Experimento 1 .................

64 Estimativas dos coeficientes da regressão polinomial: intercepto (a), linear (b) e quadrática (c) para comparação entre os diferentes genótipos dos parâmetros rendimento ( $\mathrm{R}, \mathrm{kg} / \mathrm{ha})$, massa de 1000 grãos $\left(\mathrm{M}_{1000}, \mathrm{~g}\right)$, leitura do clorofilômetro (leitura SPAD, Lc), índice de área foliar (IAF, $\mathrm{m}^{2} / \mathrm{m}^{2}$ ) no florescimento e índice de severidade (IS) à P. maydis. Experimento 1

65 Estimativas dos coeficientes da regressão polinomial: intercepto (a), linear (b) e quadrática (c) para os diferentes genótipos (efeito de doses) para os parâmetros rendimento $(\mathrm{R}, \mathrm{kg} / \mathrm{ha})$, massa de 1000 grãos $\left(\mathrm{M}_{1000}, \mathrm{~g}\right)$, leitura do 
clorofilômetro (leitura SPAD, Lc), índice de área foliar (IAF, $\mathrm{m}^{2} / \mathrm{m}^{2}$ ) no florescimento e índice de severidade (IS) à P. maydis. Experimento 2.................

66 Estimativas dos coeficientes da regressão polinomial: intercepto (a), linear (b) e quadrática (c) para comparação entre os diferentes genótipos dos parâmetros rendimento ( $\mathrm{R}, \mathrm{kg} / \mathrm{ha})$, massa de 1000 grãos $\left(\mathrm{M}_{1000}\right.$, g), leitura do clorofilômetro (leitura SPAD, Lc), índice de área foliar $\left(\mathrm{IAF}, \mathrm{m}^{2} / \mathrm{m}^{2}\right.$ ) no florescimento e índice de severidade (IS) à $P$. maydis. Experimento 2................

67 Estimativas dos coeficientes da regressão polinomial: intercepto (a), linear (b) e quadrática (c) para os diferentes genótipos (efeito de doses) para os parâmetros rendimento $(\mathrm{R}, \mathrm{kg} / \mathrm{ha})$, massa de 1000 grãos $\left(\mathrm{M}_{1000}, \mathrm{~g}\right)$, leitura do clorofilômetro (leitura SPAD, Lc), índice de área foliar $\left(\mathrm{IAF}, \mathrm{m}^{2} / \mathrm{m}^{2}\right.$ ) no florescimento e índice de severidade (IS) à $P$. maydis. Experimento 3

68 Estimativas dos coeficientes da regressão polinomial: intercepto (a), linear (b) e quadrática (c) para comparação entre os diferentes genótipos dos parâmetros rendimento ( $\mathrm{R}, \mathrm{kg} / \mathrm{ha})$, massa de 1000 grãos $\left(\mathrm{M}_{1000}\right.$, g), leitura do clorofilômetro (leitura SPAD, Lc), índice de área foliar $\left(\mathrm{IAF}, \mathrm{m}^{2} / \mathrm{m}^{2}\right.$ ) no florescimento e índice de severidade (IS) à $P$. maydis. Experimento 3

69 Estimativas dos coeficientes da regressão polinomial: intercepto (a), linear (b) e quadrática (c) para os diferentes genótipos (efeito de doses) para os parâmetros rendimento $(\mathrm{R}, \mathrm{kg} / \mathrm{ha})$, massa de 1000 grãos $\left(\mathrm{M}_{1000}, \mathrm{~g}\right)$, leitura do clorofilômetro (leitura SPAD, Lc), índice de área foliar $\left(\mathrm{IAF}, \mathrm{m}^{2} / \mathrm{m}^{2}\right.$ ) no florescimento e índice de severidade (IS) à $P$. maydis. Experimento 4

70 Estimativas dos coeficientes da regressão polinomial: intercepto (a), linear (b) e quadrática (c) para comparação entre os diferentes genótipos dos parâmetros rendimento ( $\mathrm{R}, \mathrm{kg} / \mathrm{ha})$, massa de 1000 grãos $\left(\mathrm{M}_{1000}, \mathrm{~g}\right)$, leitura do clorofilômetro (leitura SPAD, Lc), índice de área foliar $\left(\mathrm{IAF}, \mathrm{m}^{2} / \mathrm{m}^{2}\right.$ ) no florescimento e índice de severidade (IS) à P. maydis. Experimento 4 


\section{SEVERIDADE DE Phaeosphaeria maydis E RENDIMENTO DE GRÃOS DE MILHO (Zea mays L.) EM DIFERENTES AMBIENTES E DOSES DE NITROGÊNIO}

Autor: Flávio Murilo Pereira da Costa

Orientador: Durval Dourado-Neto

\section{RESUMO}

O manejo da cultura de milho (Zea mays L.) tem incorporado os recentes avanços tecnológicos em agricultura, o que tem proporcionado aumentos significativos de rendimento. Procedimentos relativos à redução da severidade de doenças, como a causada por Phaeosphaeria maydis, tornam-se prementes. O fungo é um agente biótico que promove redução de produtividade. Tal fato está relacionado com o estresse da planta, com a severidade da doença e com as condições climáticas, principalmente umidade relativa e temperatura do ar. A ênfase da pesquisa é a de nortear mais detalhadamente as ações de manejo levando em consideração esses fatores, estabelecendo técnicas culturais racionais quando da utilização de genótipos susceptíveis. Por outro lado, mesmo utilizando genótipos tolerantes, um manejo nutricional inadequado da cultura sob condições climáticas favoráveis à doença, pode ser constatada a incidência de $P$. maydis com maior severidade. Sendo assim, com o objetivo de avaliar cinco diferentes genótipos de milho, sendo quatro tolerantes a $P$. maydis e um susceptível, foram conduzidos ensaios em quatro épocas de semeadura, as duas primeiras no campus "Luiz de Queiroz" (Local 1) e as duas últimas na Estação Experimental de Anhembi (Local 2), ambos no município de Piracicaba, sob a influência de cinco doses de nitrogênio $(0 ; 60 ; 120 ; 180$ e 240 kg/ha). De acordo com os resultados obtidos, concluiu-se que: (i) o desempenho do genótipo é dependente da época de semeadura, e a adubação nitrogenada propicia aumento no rendimento de grãos apenas 
quando a condição ambiental não é limitante; e (ii) a severidade de $P$. maydis é dependente da época de semeadura, da dose de nitrogênio e do material genético. $\mathrm{O}$ estresse da planta provocado por elevadas temperaturas predispõe a cultura à incidência da doença com maior severidade. 


\section{SEVERITY OF Phaeosphaeria maydis AND GRAIN YIELD OF MAIZE (Zea mays L.) IN SEVERAL ENVIRONMENTS AND NITROGEN DOSES}

Author: Flávio Murilo Pereira da Costa

Adviser: Durval Dourado-Neto

\section{SUMMARY}

Maize (Zea mays L.) crop management is incorporating the ultimate technological advances in Agriculture, resulting in higher yield. Procedures to reduce diseases severity, as those caused by Phaeosphaeria maydis, are becoming more important. The fungus is a biotic agent that reduces productivity due to plant stress. This is related to disease severity and climatic conditions, mainly air temperature and relative humidity. The research had the emphasis of getting better orientation for management actions, using rational agricultural techniques when susceptible genotypes are used. Under favorable climatic condition for $P$. maydis, the inadequate crop nutritional management results in higher severity even using tolerant genotypes. Therefore, with the purpose of evaluating five different maize genotypes (four tolerant and one susceptible to P. maydis), the field experiments were carried out in four sowing dates, the first two at "Luiz de Queiroz" campus (Location 1) and the last two at Anhembi Experimental Station (Location 2), both in Piracicaba county, São Paulo State, Brazil, making four environments, all under the influence of five nitrogen doses $(0 ; 60 ; 120 ; 180$ e 240 $\mathrm{kg} / \mathrm{ha}$ ). According to the results, we concluded: (i) the genotype performance depends on the sowing date, and the nitrogen fertilization increases grain yield only without environmental limitation to plant growth; and (ii) the $P$. maydis severity depends on the sowing date, nitrogen fertilization dose and genotype susceptibility. The stress caused by high air temperature results in higher severity incidence of $P$. maydis. 


\section{INTRODUÇÃO}

$\mathrm{O}$ milho (Zea mays L.), em função de seu potencial produtivo, composição química e valor nutritivo, constitui-se num dos mais importantes cereais cultivados e consumidos no mundo. Em termos de produção, o Brasil é o terceiro maior produtor (FAO, 1998). Essa cultura, quando comparada a outras espécies cultivadas, tem obtido significativos avanços nas diferentes áreas do conhecimento agronômico, o qual tem possibilitado melhor compreensão de suas interações com o ambiente (relação entre a planta e os diferentes agentes bióticos e abióticos do sistema produtivo). Tal fato é fundamental para nortear a intervenção eficiente (manejo) do Homem no processo produtivo.

No Brasil, o rendimento médio da cultura do milho é de apenas $2.760 \mathrm{~kg} / \mathrm{ha} \mathrm{(FNP,}$ 2000). Todavia, práticas corretas de manejo podem ser determinantes para a condução adequada da cultura, visto que a integração de informações sobre a planta e os elementos bióticos (pragas e doenças, principalmente) e abióticos (clima e solo) pode auxiliar tanto o produtor quanto o pesquisador no desenvolvimento de tecnologia de produção (Dourado-Neto, 1999).

A exploração tecnificada emprega sementes de milho híbrido, principalmente nas regiões Centro-Sul e Centro-Oeste do país, apesar do custo ser mais elevado. Contudo, essa utilização proporciona maior rendimento e lucratividade ao produtor. Entretanto, existe grande variação nos genótipos disponíveis no mercado quanto ao padrão de resposta ao nível de tecnologia empregado, bem como ao padrão de resistência às principais doenças incidentes na cultura. Como produtividade e resistência a doenças geralmente são negativamente correlacionadas, existem híbridos de excelente potencial de produtividade, porém que apresentam níveis insatisfatórios de resistência a pragas e doenças. Esse problema se agrava ante à extrema variabilidade de condições ambientais nas regiões 
produtoras de milho, quanto à ação dos agentes bióticos e abióticos, que podem inviabilizar a exploração agrícola quando utilizam sementes de milho híbrido com padrões de desempenho às doenças pouco definidos. De fato, esse problema tem ocorrido freqüentemente no Brasil e há casos onde se registram perda total devido à severa incidência de doenças (Ferreira, 1999).

Os principais fatores de produção referentes à cultura de milho são: população de plantas, material genético, clima e adubação nitrogenada, os quais estão relacionados à incidência e severidade de doenças.

Nesse sentido, o presente trabalho foi desenvolvido com base nas seguintes hipóteses: (i) que o rendimento potencial de grãos de milho é determinado pela interação entre o material genético e as condições climáticas durante o ciclo da cultura; (ii) que o rendimento de grãos é sempre inferior ao rendimento potencial em função do estresse do ambiente (fatores bióticos e abióticos); (iii) a incidência de doença na cultura de milho (neste trabalho, o agente causal estudado foi Phaeosphaeria maydis), dentre outros fatores, é dependente do material genético (foram utilizados cinco genótipos neste trabalho), do ambiente (foram utilizados 4 épocas de semeaduras em dois locais diferentes neste trabalho) e da adubação nitrogenada (foram utilizadas cinco doses crescentes de nitrogênio neste trabalho); e (iv) o efeito do ambiente no desempenho do rendimento de genótipos de milho, sob diferentes disponibilidades de nitrogênio, pode ser caracterizado através de parâmetros fitotécnicos.

O presente trabalho teve por objetivo caracterizar e quantificar o efeito da adubação nitrogenada na severidade da doença causada por Phaeosphaeria maydis e no rendimento de grãos de alguns genótipos de milho em diferentes ambientes. 


\section{REVISÃO DE LITERATURA}

\subsection{Fenologia}

O milho é uma planta que apresenta variações quanto à sua fase vegetativa, evidenciando desde genótipos extremamente precoces, cuja polinização pode ocorrer 30 dias após a emergência, tornando o ciclo extremamente curto, até materiais extremamente tardios, cujo ciclo pode se estender por até 300 dias. Contudo, em nossas condições, a cultura do milho apresenta ciclo variável entre 110 e 180 dias, em função da diversidade de genótipos existentes.

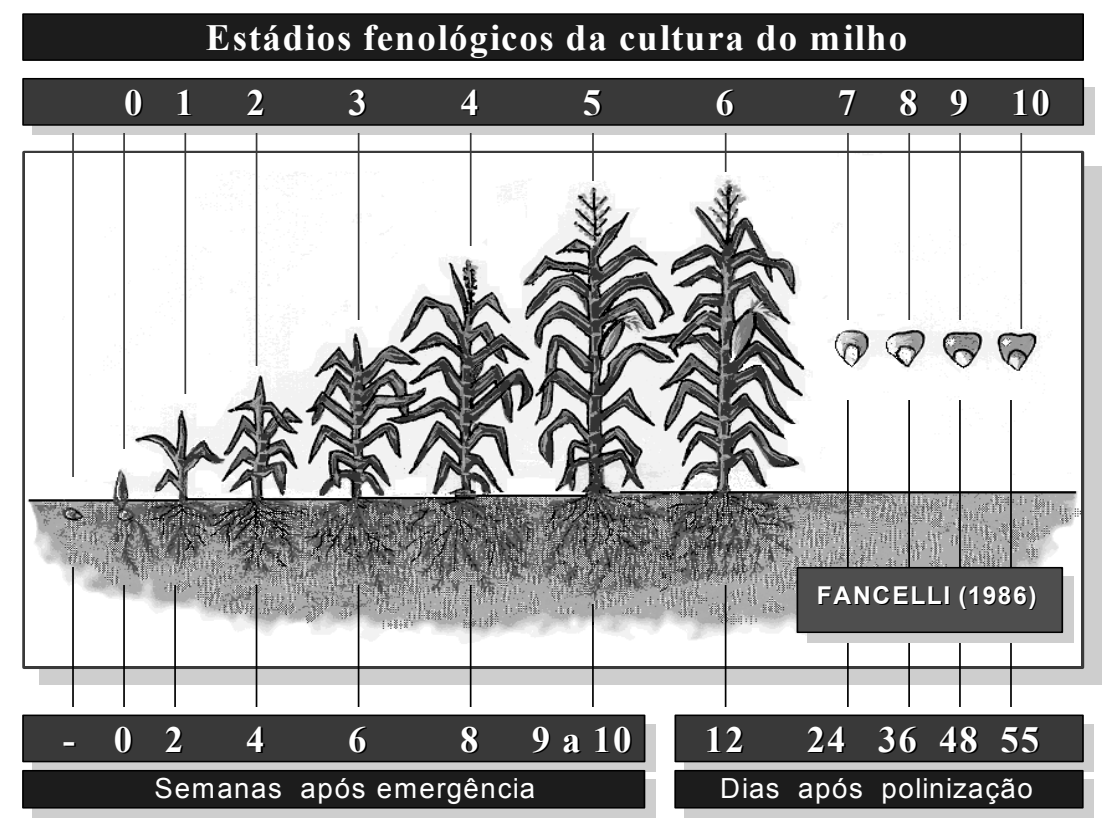

Figura 1 - Ciclo da cultura: estádios de crescimento e desenvolvimento referentes fase vegetativa (0 a 5) e fase reprodutiva (6 a 10) (Fancelli, 1986). 
O ciclo é o período compreendido entre a semeadura e a colheita (para efeito prático) ou entre a emergência e o ponto de maturidade fisiológica (para efeito de planejamento) em função de graus-dia (Fancelli \& Dourado-Neto, 2000) (Figura 1).

O estádio fenológico representa a caracterização morfológica do material genético em função dos eventos fisiológicos da planta (Tabela 1).

Tabela 1. Descrição sucinta dos estádios fenológicos da cultura de milho (Fancelli \& Dourado-Neto, 2000).

\begin{tabular}{cl}
\hline Estádio fenológico & \multicolumn{1}{c}{ Descrição sucinta } \\
\hline Estádio 0 & emergência \\
Estádio 1 & $50 \%$ das plantas com 4 folhas completamente desenvolvidas \\
Estádio 2 & $50 \%$ das plantas com 8 folhas completamente desenvolvidas \\
Estádio 3 & $50 \%$ das plantas com 12 folhas completamente desenvolvidas \\
Estádio 4 & $50 \%$ das plantas com emissão do pendão \\
Estádio 5 & $50 \%$ das plantas com florescimento e polinização \\
Estádio 6 & $50 \%$ das plantas com grãos no estado leitoso \\
Estádio 7 & $50 \%$ das plantas com grãos no estado pastoso \\
Estádio 8 & $50 \%$ das plantas com início da formação de "dentes" \\
Estádio 9 & $50 \%$ das plantas com grãos “duros” \\
Estádio 10 & $50 \%$ das plantas com grãos maduros fisiologicamente \\
\hline
\end{tabular}

\subsection{Interação entre genótipo e ambiente}

Afirma-se que há interação entre o genótipo e o ambiente quando o desempenho relativo dos genótipos é inconstante de um ambiente para outro. De maneira geral, são reconhecidos três tipos de interação: (i) ausência de interação: quando os genótipos apresentam valores relativos não diferenciados nos vários ambientes, ou seja, o mérito relativo dos genótipos não se altera de um para outro ambiente; (ii) interação simples quantitativa: quando o desempenho relativo dos genótipos é diferenciado entre ambientes diferentes, mas a ordem de classificação do mérito dos genótipos não se altera; e (iii) interação cruzada ou qualitativa: quando os genótipos apresentam 
desempenho diferenciado, mas os méritos relativos alteram entre os ambientes (Chaves, 2001).

Essa alteração na performance relativa dos genótipos, em virtude de diferenças de ambiente é, portanto, denominada interação entre genótipo e ambiente. Para detectar a referida interação, os diferentes genótipos devem ser avaliados em dois ou mais ambientes contrastantes, que podem também ser denominados de "microambientes", quando se utilizam um mesmo local, mas em épocas distintas de avaliações (Boné, 1997).

\subsection{Estresse do ambiente}

O estresse ambiental deve ser entendido como qualquer fator do ambiente que possa causar dano à planta e que venha limitar o seu crescimento e desenvolvimento (Monteiro, 1995). A temperatura, regime de chuvas, ventos, luz e umidade estão entre os principais fatores do clima.

\subsubsection{Temperatura}

Do ponto de vista das exigências climáticas, a temperatura se constitui em um dos fatores de produção mais importante e decisivo para o crescimento e desenvolvimento da cultura de milho. Temperaturas médias diurnas inferiores a $19^{\circ} \mathrm{C}$ e noites com temperaturas médias abaixo de $13^{\circ} \mathrm{C}$, são consideradas inadequadas para o processo metabólico das plantas de milho. Ainda, temperaturas do solo inferiores a $10^{\circ} \mathrm{C}$ e superiores a $42^{\circ} \mathrm{C}$ prejudicam sensivelmente a emergência de plântulas de milho e o seu desenvolvimento, respectivamente. Nesse sentido, durante o crescimento e desenvolvimento das plantas, a temperatura média do ar deverá estar em torno de $25^{\circ} \mathrm{C}$, associada à adequada disponibilidade de água no solo e radiação solar (Fancelli \& Dourado-Neto, 1997).

Por ocasião do período de florescimento e maturação, temperaturas médias diárias superiores a $26^{\circ} \mathrm{C}$ podem promover a aceleração dessas fases e, por outro lado, temperaturas inferiores a $15^{\circ} \mathrm{C}$ podem prontamente retardá-las (Berger, 1962). 
Temperaturas superiores a $35^{\circ} \mathrm{C}$, por ocasião do período de formação do grão podem reduzir o rendimento de grãos de milho, bem como alterar a composição protéica dos grãos. Tal efeito, está relacionado à diminuição da redutase do nitrato e, conseqüentemente, interferindo no processo de transformação do nitrogênio disponível para a planta (Fancelli \& Dourado-Neto, 1997).

\subsubsection{Luz}

O milho, mediante seleção orientada de variedades cultivadas e híbridos, vem sendo explorado nos mais diversos ambientes, desde $58^{\circ}$ de latitude Norte (Canadá e União Soviética) a $40^{\circ}$ de latitude Sul (Argentina). As altitudes podem variar entre 3.000 m (Andes peruanos) até regiões abaixo do nível do mar (regiões do mar Cáspio). Diante desses aspectos, pode-se dizer que o milho é uma planta amplamente especializada (Vieira Júnior, 1999).

Dessa maneira, as variações de intensidade luminosa são diferenciadas conforme a latitude. Em relação à luz, sabe-se que a cultura de milho responde com altos rendimentos a intensidades luminosas crescentes, em virtude de pertencer ao grupo das plantas de fisiologia $\mathrm{C}_{4}$, o que the confere alta produtividade biológica (Fancelli \& Dourado-Neto, 1996).

O milho é uma planta de dias curtos. A ocorrência de dias longos pode promover o aumento de sua fase vegetativa, ocasionando o atraso no florescimento (Ferraz, 1966). Uma redução de 30 a 40\% da intensidade luminosa, na cultura do milho ocasiona um atraso na maturação dos grãos. A maior sensibilidade à variação de luminosidade é verificada no início da fase reprodutiva, 10 a 15 dias após o florescimento (Fancelli \& Dourado-Neto, 1997).

\subsubsection{Vento}

O vento também é um fator que pode afetar o rendimento da cultura. A sua incidência em lavouras de milho pode aumentar a demanda de água por parte da planta, tornando-a mais susceptível aos períodos curtos de estiagem, além de promover o acamamento da cultura. Da mesma forma, ventos frios ou quentes podem ocasionar 
falhas na polinização, constituindo-se, freqüentemente, em importante fator limitante na produção de milho de algumas regiões (Arnon, 1975).

\subsubsection{Estresse hídrico}

A disponibilidade hídrica é um dos fatores ambientais de maior efeito limitante sobre o crescimento e rendimento da cultura do milho (Rossielo \& Pimentel, 1995) em áreas tropicais.

Um dos primeiros efeitos do estresse hídrico está relacionado com a redução da atividade fotossintética, pela diminuição da disponibilidade de $\mathrm{CO}_{2}$ devido ao fechamento estomático (Boyer ${ }^{1}$, 1976, citado por Rossielo \& Pimentel, 1995). Com a restrição de água, o potencial de turgescência da folha diminui, afetando a expansão da área foliar, reduzindo a atividade de enzimas e a biossíntese de proteínas.

Os períodos críticos em exigência de água para a cultura de milho concentram-se na fase de emergência, florescimento e formação do grão. Todavia, no período compreendido entre 15 dias antes (“emborrachamento") e 15 dias após o pleno florescimento (grãos leitosos), o requerimento de um suprimento hídrico satisfatório aliado a temperaturas adequadas tornam tal período extremamente crítico. Esta fase deverá coincidir com o período estacional que apresente temperaturas favoráveis (25 a $30^{\circ} \mathrm{C}$ ) e umidade adequada (Frattini, 1975).

O sincronismo entre o florescimento masculino e feminino pode ser utilizado como um indicativo para tolerância ao estresse hídrico. Estresses hídricos podem ocasionar a redução no vigor vegetativo e na altura da planta, bem como na produção e fertilidade do pólen, além de alterar sobremaneira o sincronismo mencionado (Fancelli \& Dourado-Neto, 1997).

Períodos de deficiência hídrica de uma semana por ocasião do pendoamento podem provocar queda de produção ao redor de 40 a 50\%, ao passo que sob as mesmas condições, escassez hídrica posterior à polinização acarretará danos à produção da ordem de 25 a $32 \%$.

\footnotetext{
${ }^{1}$ BOYER, J.S. Water deficits and photosynthesis. In: KOSLOWSKI, T.T. Water deficits and plant growth. New York: Academic Press, 1976. Vol.4, p.153-190.
} 
Para conhecer o efeito da adubação nitrogenada sobre o ajuste osmótico em milho e sorgo, Bataglia et al.(1985) conduziram experimentos em casa-de-vegetação, sob dois níveis de nitrogênio, com e sem estresse de água. Em condições de seca moderada ou veranicos curtos, plantas bem supridas de nitrogênio mostraram maior capacidade de ajuste osmótico através do acúmulo de compostos nitrogenados e outros assimilados, conseguindo desse modo explorar com maior eficiência a água disponível no solo do que as plantas deficientes em nitrogênio.

\subsubsection{Estresse fisiológico}

Os processos da fotossíntese, respiração, transpiração e evaporação são funções diretas da energia disponível no ambiente, comumente designada por calor, ao passo que, crescimento, desenvolvimento e translocação de fotoassimilados se encontram ligados à disponibilidade hídrica do solo, sendo seus efeitos mais pronunciados em condições de altas temperaturas, onde a taxa de evapotranspiração é elevada (Fancelli \& Dourado-Neto, 1996).

Apesar do elevado potencial produtivo, o milho apresenta acentuada sensibilidade a estresse de natureza biótica e abiótica. Dessa forma, seu cultivo necessita ser rigorosamente planejado e criteriosamente manejado, objetivando a manifestação de sua capacidade produtiva (Andrade, 1995).

O aproveitamento efetivo da luz por parte do milho é decisivamente influenciado pela distribuição espacial das plantas na área, pelo arranjo das folhas na planta e pela extensão da área foliar presente. Trabalhos experimentais demonstram que, quando o índice de área foliar é baixo, plantas com arquitetura foliar horizontal são mais eficientes na interceptação da luz. Em contrapartida, plantas com folhas mais eretas podem contribuir significativamente para o incremento da produtividade biológica, em função do aumento da área foliar por unidade de área de solo explorado pela cultura (Magalhães \& Silva, 1987).

As lesões ocorridas nas folhas produzem uma redução na área fotossinteticamente ativa, aumentando a respiração e diminuindo a translocação de assimilados, com conseqüente diminuição de biomassa, tanto na parte aérea como nas raízes (Presello \& 
Morata, 1998). Da mesma forma, Dudienas et al. (1998) constataram, devido à severidade da doença causada por $P$. maydis, redução de $40 \%$ de área foliar, aproximadamente, em genótipos susceptíveis. Nessa mesma situação, genótipos considerados tolerantes (notas médias abaixo de 4, em escala de 1 a 9) ainda apresentaram 20\% de área foliar afetada. Fancelli (1988) observou que, a destruição de $25 \%$ da área foliar do milho próxima ao florescimento foi responsável pela redução de $32 \%$ no rendimento.

\subsubsection{Estresse nutricional}

Estresses nutricionais ocasionam decréscimos no rendimento e na qualidade do produto colhido. Portanto, sempre que possível, o controle das desordens nutricionais deve ser realizado de forma integrada com os métodos de correção e prevenção, pois esse procedimento minimiza os custos de fertilizantes e corretivos.

De maneira geral, para a seleção de genótipos visando o estresse nutricional existe uma grande disponibilidade de germoplasmas em função da ocorrência de considerável variabilidade entre os genótipos para a maioria das espécies cultivadas. $\mathrm{O}$ aspecto mais relevante está na capacidade de absorção e utilização dos nutrientes ou na tolerância a toxicidades minerais. Sendo assim, isso permite que sejam identificados e selecionados genótipos eficientes no aproveitamento de nutrientes em níveis abaixo ou acima do adequado ou, na tolerância a elementos potencialmente tóxicos (Lima Filho, 1999).

Em solos altamente intemperizados, a disponibilidade limitada de fósforo pode causar, com freqüência, estresse nutricional desse nutriente. A deficiência de fósforo pode induzir a deficiência de nitrogênio, enquanto que a absorção do nutriente nitrogenado está estreitamente relacionada ao status de fósforo na planta e no solo. Magalhães (1996), avaliando em solução nutritiva, verificou alterações na absorção e translocação de nitrogênio em plantas de milho, provocadas pela omissão de fósforo por diferentes períodos. Yamada (1995), observou que tal fato diminuiu a absorção de nitrato e de amônio e pode reduzir a disponibilidade de micronutrientes como ferro, manganês e zinco, muito envolvidos no mecanismo de resistência das plantas às 
doenças. Da mesma forma, a deficiência de potássio e de cálcio desempenham papel importante na incidência das doenças.

Mais que a ação de cada nutriente, o equilíbrio nutricional parece ser de suma importância à sanidade vegetal, devido à complexidade dos efeitos antagônicos e/ou sinérgicos existentes entre os macros e os micronutrientes (Yamada, 1995).

\subsection{Adubação nitrogenada}

O nitrogênio é o nutriente que proporciona maior aumento de rendimento de grãos na cultura do milho por ser constituinte de moléculas de proteínas (enzimas e coenzimas), ácidos nucléicos e citocromos, além de sua importante função como integrante da molécula de clorofila (Neptune et al., 1982). Bull (1993) cita que vários autores ressaltam os efeitos do nitrogênio no aumento do rendimento de grãos da cultura de milho.

A formação de grãos na cultura do milho está estreitamente relacionada com a translocação de açúcares (Crawford et al., 1982) e de nitrogênio de órgãos vegetativos (Karlen et al., 1988), principalmente das folhas para os grãos. Assim, é evidente a relação entre a área foliar e a rendimento de grãos. Isso ocorre basicamente devido à maior capacidade que as folhas, bem nutridas em nitrogênio, têm de assimilar $\mathrm{CO}_{2} \mathrm{e}$ sintetizar carboidratos durante a fotossíntese, resultando em maior acúmulo de biomassa. Consequentemente, sob condições de deficiência de nitrogênio, a divisão celular é retardada nos pontos de crescimento, o que resulta em uma redução na área foliar e no tamanho da planta (Arnon, 1975), com reflexos no rendimento de grãos.

O aumento do rendimento proporcionado pelo nitrogênio pode ser atribuído, também, aos seus efeitos sobre o crescimento do sistema radicular, sobre o aumento do comprimento da espiga (Balko \& Russell, 1980) e do número de espigas por planta (Balko \& Russell, 1980; Ebelhar et al., 1987).

O nitrogênio, juntamente com o potássio, são os dois nutrientes mais absorvidos pela cultura do milho, com $191 \mathrm{~kg} / \mathrm{ha}$ de nitrogênio e $235 \mathrm{~kg} / \mathrm{ha}$ de $\mathrm{K}_{2} \mathrm{O}$, mesmo para genótipos de baixo rendimento de grãos. Rendimentos da ordem de $9.500 \mathrm{~kg} / \mathrm{ha}$ têm sido obtidos com o uso de $40 \mathrm{~kg} / \mathrm{ha}$ de nitrogênio aplicados na semeadura mais $80 \mathrm{~kg} / \mathrm{ha}$ de 
nitrogênio em cobertura no estádio $\mathrm{V}_{4}$. Nessas proporções, respostas à interação entre $\mathrm{N}$ e K, na dose de $120 \mathrm{~kg} / \mathrm{ha}$ de nitrogênio, foram observadas respostas positivas a potássio até a relação $\mathrm{N}: \mathrm{K}$ de 1,0:1,3, com tendências a relações ainda maiores (Yamada, 1997).

De maneira geral, Fancelli \& Dourado-Neto (1996) recomendam a aplicação de 30 $\mathrm{kg} / \mathrm{ha}$ de nitrogênio na semeadura (principalmente em sistemas de semeadura direta e para materiais superprecoces) e o restante (até $100 \mathrm{~kg} / \mathrm{ha}$ ) dividido em duas aplicações iguais quando a planta apresentar 4 e 8 folhas, respectivamente. Para solos com baixo potencial de lixiviação (solos argilosos), esses autores recomendam reduzir o parcelamento a duas aplicações: na semeadura (30 a $40 \mathrm{~kg} / \mathrm{ha}$ de nitrogênio), e o restante quando a planta apresentar quatro folhas completamente desenvolvidas. Dessa forma, as fontes nitrogenadas mais eficientes, aplicadas na superfície do solo, seriam o nitrato de amônio e o sulfato de amônio, devido às menores perdas por lixiviação.

O nitrogênio, sob a ótica da nutrição mineral das plantas, é quase sempre analisado em termos de aumento de produtividade. No entanto, essa prática também tem efeito na qualidade do produto colhido e na resistência a ataques de pragas e doenças (Yamada, 1995). A alta concentração de nitrogênio reduz a produção de compostos fenólicos (fungiostáticos) e de lignina das folhas, diminuindo a resistência aos patógenos. Como regra, todos os fatores que favorecem as atividades metabólicas, a síntese de células hospedeiras e que atrasam a senescência da planta hospedeira (por exemplo: adubação nitrogenada), também diminuem a severidade dos parasitas facultativos, que preferem tecidos senescentes. Além disso, o $\mathrm{N}$ aumenta também a concentração de aminoácidos e de amidas no apoplasto e na superfície foliar, que aparentemente têm maior influência que os açúcares na germinação e no desenvolvimento dos conídios (Marschner, 1986), favorecendo assim, o desenvolvimento das doenças fúngicas.

A utilização de adubações equilibradas, dentro do aspecto nutricional do milho, visando o controle de doenças, pode ser uma das estratégias para minimizar o aparecimento de algumas doenças (Silva \& Menten, 1997). Para o nitrogênio e o potássio por exemplo, por ocasião da semeadura, deverá existir uma boa relação entre os dois elementos, bem como por ocasião da cobertura, com bastante atenção ao nitrogênio. Um adequado balanceamento nutricional poderá trazer benefícios para a cultura, 
principalmente quanto ao aspecto de sanidade foliar das plantas. Sendo assim, genótipos com boa resistência às doenças foliares estão menos sujeitos ao que denominamos "estresse" doença, pois exibem maior equilíbrio fisiológico, ou seja, menor desbalanceamento dos fotossintetatos no interior da planta e, portanto, maior tolerância às podridões de colmo.

\subsection{Incidência de doenças}

A mancha foliar causada por $P$. maydis vem se constituindo numa das principais doenças da cultura do milho, devido à generalidade e severidade com que ocorre. A variação da severidade dessa doença durante o ano indica uma possível interação entre a sua ocorrência e as condições ambientais predominantes. Dos parâmetros climáticos, a temperatura mínima e a umidade relativa do ar noturna são os que mais se correlacionam com a incidência da doença, bem como as semeaduras tardias. Esses fatores foram observados por Fernandes \& Sans (1994), em Sete Lagoas-MG, em dois anos consecutivos, evidenciando que para ocorrer a doença, basta que os valores da temperatura e da umidade relativa sejam iguais ou superiores a $14^{\circ} \mathrm{C}$ e $70 \%$, respectivamente, ou que qualquer um destes valores ocorra isoladamente.

Silva \& Menten (1997) relatam que as condições climáticas favoráveis à doença ocasionada por $P$. maydis são temperaturas na faixa de 24 a $30^{\circ} \mathrm{C}$, umidade relativa elevada e baixa luminosidade. Nas regiões com altitude acima de 700 metros, tem-se a ocorrência da doença devido a uma grande formação de orvalho. Os autores sugeriram também que altas doses de nitrogênio podem favorecer a doença, salientando que o importante é fazer uma adubação equilibrada entre nitrogênio, fósforo e potássio.

Para que uma doença se estabeleça, é necessário que haja uma relação íntima entre três fatores: o patógeno, que é o agente causal da doença, o hospedeiro (planta susceptível) e o ambiente, que deve ser favorável a essa interação. A crescente incidência e severidade da doença em questão são fatores que vêm contribuindo de forma marcante para a redução do rendimento de grãos da cultura de milho (PaccolaMeirelles et al., 1998). A identificação de genótipos resistentes é uma necessidade indispensável quando da utilização desses materiais em áreas de ocorrência do patógeno. 
Estudando a expressão da resistência para a mancha foliar de $P$. maydis quanto ao número e tamanho das lesões, os autores não conseguiram observar correlação entre a resistência e o tamanho. No entanto, estabeleceram diferenças quanto ao número de lesões entre 44 genótipos diferentes; dez foram altamente susceptíveis, dez foram susceptíveis, nove com resistência intermediária, cinco foram resistentes e os outros cinco restantes, altamente resistentes. Em genótipos susceptíveis, a mancha causada por P. maydis pode reduzir a produção de grãos em cerca de $60 \%$ (Fernandes \& Oliveira, 1997).

Zoccoli et al. (1996) observaram que a doença ocorre durante todo o período de cultivo de milho, mas sua severidade aumenta a partir de semeaduras de novembro em diante, tornando-se um fator limitante para esta cultura. Dentre os 29 genótipos avaliados, apenas três foram considerados resistentes e dois altamente susceptíveis, ficando os demais numa situação intermediária. Vários trabalhos evidenciam situação semelhante da incidência e severidade da doença, em relação ao avanço das épocas de semeadura (Godoy et al., 1998b; Brasil \& Carvalho, 1998; Fernandes \& Oliveira, 1999).

Segundo Menten et al. (1996), a variação em rendimento entre genótipos de milho tem sido explorada em diversos programas de melhoramento e seleção. A resistência genética é uma alternativa promissora de controle da doença. Por outro lado, os nutrientes minerais podem aumentar ou diminuir a resistência de plantas às doenças e às pragas (Marschner, 1986).

O patógeno sobrevive nos restos de culturas. Sob condições favoráveis, as estruturas de reprodução germinam e infectam folhas novas ou maduras. A doença é de fácil disseminação e a velocidade de colonização dos tecidos é rápida, de tal maneira que, em poucos dias, a planta pode ser severamente afetada (Silva \& Menten, 1997).

Parentoni et al. (1996), estudando o efeito de duas doses de nitrogênio sobre a severidade do ataque de $P$. maydis em milho, constataram que tal severidade aumentou drasticamente com o aumento do nível de nitrogênio aplicado, sendo que apenas um híbrido, dentre os testados, obteve nota mínima 1 (altamente resistente) na dose mais baixa (30 kg/ha de nitrogênio). Por outro lado, o mesmo híbrido foi tolerante na dose mais alta (130 kg/ha de nitrogênio). Os autores salientaram também que o uso de doses 
adequadas de nitrogênio pode ser um fator importante no manejo dessa doença e que o screening de genótipos tolerantes a $P$. maydis deve ser feito preferencialmente utilizando níveis elevados de nitrogênio para se obter máxima expressão dos sintomas.

\subsection{Ecofisiologia}

A planta de milho é considerada como sendo uma das mais eficientes na conversão de energia radiante e, conseqüentemente, na produção de biomassa. Assim sendo, os processos de fotossíntese e evapotranspiração são funções diretas da energia disponível, enquanto o crescimento e translocação de fotoassimilados estão mais ligados à disponibilidade hídrica (Ramos \& Mundstock, 1986). Portanto, os estádios de desenvolvimento da cultura de milho são regulados, basicamente, pela temperatura, necessitando acumular quantidades distintas de energia. Essa energia é estimada indiretamente pela soma calórica (ou número de graus-dia), para a planta completar o seu ciclo (Berlatto \& Sutili, 1976).

O conhecimento dos principais fatores que influenciam a variação temporal dos estádios fenológicos da cultura de milho subsidia escolher e adequar o genótipo ao ambiente. Tal fato, possibilita planejar a coincidência de etapas críticas com condições favoráveis de oferta dos fatores de produção (Fancelli \& Dourado-Neto, 1996).

A quantidade diferencial de radiação solar é função da localização geográfica da área de produção (latitude, longitude e altitude), bem como da época de semeadura ao longo do ano (Alfonsi,1991).

A eficiência de interceptação depende da idade, arquitetura e arranjo espacial de plantas, principalmente, ao passo que a eficiência de conversão, dentre outros fatores, depende da temperatura, estado nutricional, e equilíbrio hídrico das plantas. A partição dos fotoassimilados, sobretudo, é função do genótipo e das relações entre fonte e drenos (Fancelli \& Dourado-Neto, 1997). O suprimento de fotoassimilados durante a granação influencia diretamente o rendimento de grãos, indicando limitação para a produção em ambientes de curto período de iluminação. Cita-se como índice de área foliar ideal para a cultura valores ao redor de 5; contudo, esse índice pode variar entre 3 e 8 , em função do genótipo e do ambiente (Andrade et al., 1991). 
Pelo fato da temperatura afetar a eficiência da conversão, seria preferível utilizar a taxa de crescimento por unidade de soma calórica como medida de desempenho de genótipos de milho (Andrade et al., 1991). Da mesma forma, Hawkins \& Cooper (1981) relatam a existência de estreita correlação positiva entre o parâmetro anteriormente mencionado e rendimento de grãos.

O aumento de temperatura, principalmente noturna, além de aumentar a taxa respiratória, contribui para um maior acúmulo de graus-dia em menor espaço de tempo. Dessa maneira, esse aumento contribui para o encurtamento do ciclo da cultura e à redução do aparato fotossintético que, diretamente, diminui a quantidade de radiação interceptada, bem como reduz o potencial de produção (Fancelli \& Dourado-Neto, 1997).

O potencial de produção é definido antecipadamente, ou seja por ocasião da emissão da $4^{\mathrm{a}}$ a $5^{\mathrm{a}}$ folha, podendo se estender até a $6^{\mathrm{a}}$ folha. Essa etapa é denominada de diferenciação dos primórdios florais. A determinação do número de fileiras da espiga, ocorrerá entre o período correspondente à emissão da $7^{\text {a }}$ à $9^{\text {a }}$ folha completamente expandida. Entre os estádios correspondentes a 12 folhas e grãos leitosos, ocorre a confirmação do potencial de produção definido anteriormente. Nessa etapa, a planta deverá estar devidamente suprida de nutrientes, principalmente de nitrogênio, e não ser submetida à deficiência hídrica prolongada (Fancelli \& Dourado-Neto, 1997).

A redução da taxa fotossintética após o florescimento pode ser ocasionada por seca, excesso de chuva, nebulosidade prolongada, relação desfavorável entre $\mathrm{N}$ e K (excesso de nitrogênio), destruição de área foliar (doenças e pragas) e população excessiva. Essa situação implicará na necessidade da utilização de reservas do colmo no enchimento dos grãos que, conforme o nível de estresse gerado, poderá favorecer a incidência de fungos de solo (Fancelli, 1994).

\subsection{Graus-dia}

O número de graus-dia (ou soma calórica) é definido como sendo a diferença entre a temperatura média diária e a temperatura mínima ou temperatura basal inferior exigida por uma espécie (Villa Nova et al., 1972). 
Atualmente, os genótipos disponíveis no mercado brasileiro são classificados, quanto à fase vegetativa (período entre a emergência e o florescimento), em superprecoces, precoces e normais, apresentando, respectivamente, soma calórica inferior a $830^{\circ} \mathrm{C}$.dia (Graus-dia), entre 830 e $900^{\circ} \mathrm{C}$.dia e acima de $900^{\circ} \mathrm{C}$.dia para o florescimento (Vieira Júnior, 1999).

O prolongamento ou a redução do período vegetativo compromete o rendimento de grãos (Fancelli \& Dourado-Neto, 1996). No caso de redução do período vegetativo, os genótipos de baixa soma calórica em locais de alta temperatura do ar, além de apresentarem redução do índice de área foliar (IAF), mostram maior predisposição da planta a doenças, em virtude do estresse provocado pela inadequação do genótipo às condições ambientais.

Pacheco et al. (1999), avaliando genótipos de ciclo normal, precoce e superprecoce em semeadura de novembro, observaram que híbridos de ciclo normal mostraram tendência a maior resistência que os precoces e superprecoces, respectivamente. Quanto maior o nível de severidade, menor o rendimento de grãos, desconsiderando-se diferenças prováveis de rendimento potencial de cada material e as pequenas diferenças de ciclo existentes entre os materiais do mesmo grupo. Nesse sentido, constata-se que germoplasmas de ciclo normal (predominantemente de origem tropical) são mais tolerantes à $P$. maydis do que aqueles que apresentam ciclos precoces ou superprecoces, que em sua maioria são obtidos a partir de linhagens de milho de regiões temperadas. 


\section{MATERIAL E MÉTODOS}

\subsection{Caracterização dos locais dos experimentos}

O presente trabalho foi conduzido em duas áreas experimentais: (i) a primeira sob a égide do Departamento de Produção Vegetal da Escola Superior de Agricultura "Luiz de Queiroz", da Universidade de São Paulo (ESALQ/USP), no município de Piracicaba, SP ( $22^{\circ} 42$ ' $30^{\prime \prime}$ de latitude Sul, $47^{\circ} 38^{\prime} 00^{\prime \prime}$ de longitude Oeste e $546 \mathrm{~m}$ de altitude), sob condições irrigadas (sistema por aspersão do tipo pivô central); e (ii) a segunda em área experimental da Estação Experimental de Anhembi do Departamento de Genética da mesma instituição, no município de Piracicaba, SP, bairro de Anhumas, também sob condições irrigadas (sistema de irrigação por aspersão do tipo convencional) (Tabela 2).

O estudo foi realizado em dois períodos distintos para cada localidade, sendo praticada a semeadura em quatro épocas diferentes, totalizando quatro experimentos.

Tabela 2. Caracterização dos locais dos quatro experimentos conduzidos para realização deste trabalho e suas respectivas datas de semeadura e de colheita.

\begin{tabular}{ccccc}
\hline Experimento & Local & \multicolumn{2}{c}{ Data } & \multirow{2}{*}{ Época } \\
\cline { 3 - 4 } & & Semeadura & Colheita & \\
\hline 1 & Campus “Luiz de Queiroz" & $11 / 09 / 00$ & $26 / 01 / 01$ & Cedo \\
2 & Campus "Luiz de Queiroz" & $29 / 11 / 00$ & $20 / 04 / 01$ & Normal \\
3 & Estação Experimental de Anhembi ${ }^{2}$ & $27 / 12 / 00$ & $08 / 05 / 01$ & Tardia \\
4 & Estação Experimental de Anhembi & $22 / 02 / 01$ & $30 / 06 / 01$ & Safrinha \\
\hline 1 Departamento de Producão Vegetal, Escola Superior de Agricultura “Luiz de Queiroz", Universidade de São Paulo \\
2 Departamento de Genética, Escola Superior de Agricultura "Luiz de Queiroz", Universidade de São Paulo
\end{tabular}




\subsection{Dados meteorológicos}

Os dados meteorológicos foram fornecidos pelo Posto Agrometeorológico automatizado do Departamento de Produção Vegetal da ESALQ/USP, instalado próximo ao local dos experimentos (Experimentos 1 e 2 ), onde foram determinados os seguintes atributos climáticos: temperatura do ar, chuva, umidade relativa e radiação solar.

\subsection{Material genético}

Foram utilizados cinco híbridos simples comerciais de milho, sendo quatro genótipos que possuindo indicações de resistência à $P$. maydis e um genótipo como testemunha susceptível à doença, conforme informação fornecida pelas empresas produtoras (Tabela 3 ).

Tabela 3. Descrição sucinta dos cinco genótipos utilizados nos quatro experimentos (informação fornecida pelas empresas produtoras).

\begin{tabular}{|c|c|c|c|c|c|c|c|c|c|}
\hline \multirow[t]{2}{*}{ Genótipo } & \multirow[t]{2}{*}{ Híbrido } & \multirow[t]{2}{*}{ Tipo $^{1}$} & \multirow[t]{2}{*}{$\mathrm{GD}^{2}$} & \multirow{2}{*}{$\begin{array}{c}\text { Classificação } \\
\text { comercial }\end{array}$} & \multirow[t]{2}{*}{ P. maydis } & \multirow[t]{2}{*}{ Indicação $^{3}$} & \multirow[t]{2}{*}{ Semeadura $^{4}$} & \multicolumn{2}{|c|}{ Grão } \\
\hline & & & & & & & & Cor & Tipo \\
\hline 1 & P-30F45 & $\mathrm{S}$ & 850 & Precoce & "Susceptível" & $\mathrm{TR} / \mathrm{TS}$ & $2 ; 3$ & Laranja & Flint \\
\hline 2 & C-333B & SM & 970 & Normal & "Tolerante" & $\mathrm{TR} / \mathrm{TS} / \mathrm{ST}$ & $2 ; 3 ; 4$ & Laranja & Flint \\
\hline 3 & P-30K75 & $\mathrm{S}$ & 878 & Precoce & "Média Resistência" & $\mathrm{TR} / \mathrm{TS} / \mathrm{ST}$ & $2 ; 3$ & Laranja & Semiduro \\
\hline 4 & CO-9560 & $\mathrm{S}$ & 825 & Superprecoce & "Resistente" & $\mathrm{TR} / \mathrm{TS} / \mathrm{ST}$ & $2 ; 3 ; 4$ & Laranja & Semiduro \\
\hline 5 & C-909 & $\mathrm{S}$ & 810 & Superprecoce & "Tolerante" & $\mathrm{TR} / \mathrm{TS} / \mathrm{ST}$ & $1 ; 2 ; 3 ; 4$ & Laranja & Flint \\
\hline
\end{tabular}

1 Tipo: S: híbrido simples; SM: híbrido simples modificado

2 GD: número de graus-dia para o florescimento $\left({ }^{\circ} \mathrm{C}\right.$.dia $)$

3 Indicação: TR: Tropical; TS: Transição e ST: Subtropical

4 Semeadura: 1: cedo, 2: normal, 3: tardio e 4: safrinha (recomendação das empresas produtoras)

\subsection{Delineamento experimental e análise estatística}

Os cinco genótipos utilizados estiveram sob a influência de cinco doses crescentes de adubação nitrogenada $(0 ; 60 ; 120 ; 180$ e $240 \mathrm{~kg} / \mathrm{ha}$ de nitrogênio), utilizando o fertilizante sulfato de amônia como fonte.

Nos quatro experimentos foi utilizado o delineamento em blocos casualizados, com três repetições. Os tratamentos constituíram-se de combinações dos fatores 
genótipos e doses de nitrogênio, arranjados no esquema fatorial, totalizando 25 tratamentos em cada época de semeadura para cada local (Tabela 2).

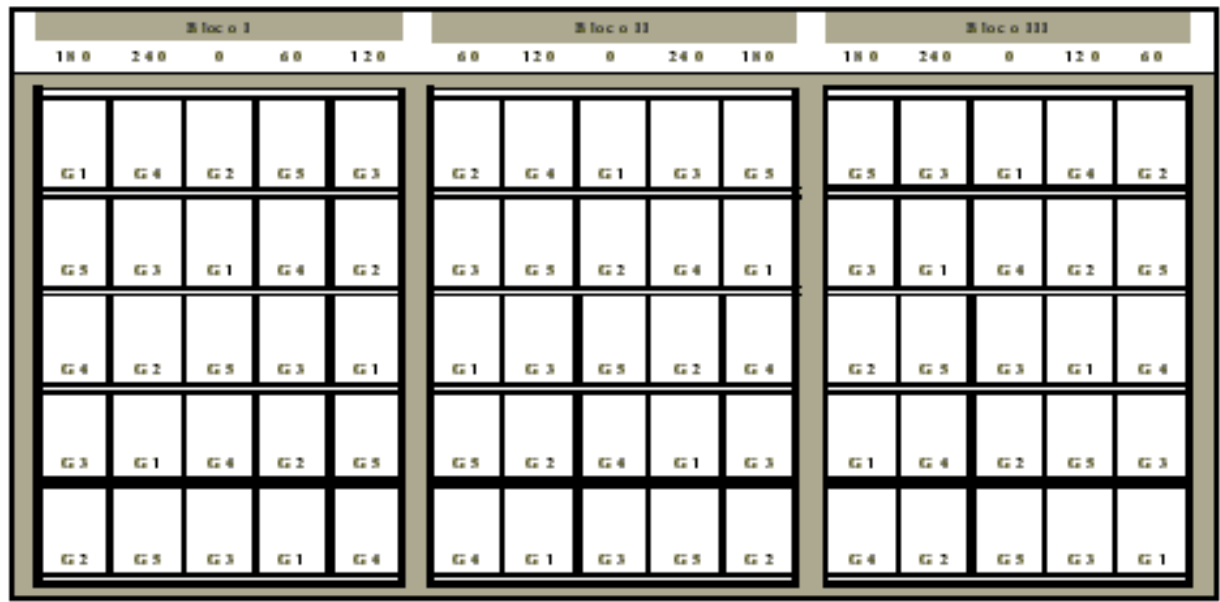

(A)

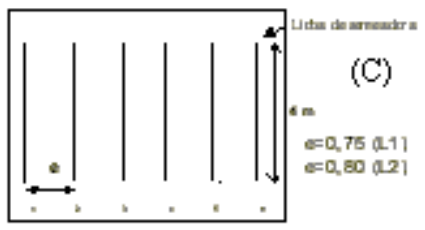

(B) 25 parcod as esperinnertaks por blow

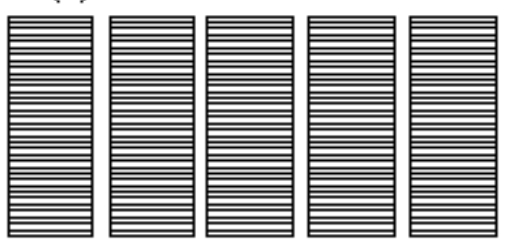

Figura 2 - Representação esquemática da área experimental: (A) os três blocos, (B) as 25 parcelas experimentais em um bloco, e (C) a parcela experimental indicando a área útil para determinação do rendimento de grãos e o espaçamento " $e$ " $(0,75 \mathrm{~m}$ para o local 1 e $0,80 \mathrm{~m}$ para o local 2$)$.

Cada unidade experimental foi constituída de seis linhas de 4,0m de comprimento, com espaçamento de $0,75 \mathrm{~m}$ (local 1) e 0,80m (local 2) entre linhas, resultando as seguintes populações: (i) 70.000 plantas/ha (local 1) e (ii) 65.625 plantas/ha (local 2) (Figura 2).

As duas linhas extremas de semeadura foram consideradas bordaduras, totalizando, portanto, quatro linhas centrais de parcela útil para as determinações dos componentes de produção e demais parâmetros, como índice de área foliar, teor de clorofila, comprimento do primeiro internódio, diâmetro do colmo e índice de severidade referente à doença causada por $P$. maydis (área útil: $12,0 \mathrm{~m}^{2}$ para o local $1 \mathrm{e}$ 
$12,8 \mathrm{~m}^{2}$ para o local 2). As duas linhas centrais foram reservadas para a determinação do rendimento de grãos (área útil: $6,0 \mathrm{~m}^{2}$ para o local 1 e $6,4 \mathrm{~m}^{2}$ para o local 2) (Figura 2).

Foi realizada análise de variância (Tabela 4) para as variáveis rendimento (R), massa de 1000 grãos $\left(\mathrm{M}_{1000}\right)$, teor de clorofila no estádio $8\left(\mathrm{TC}_{8}\right)$, índice de área foliar no florescimento (IAF5) e índice de severidade de P. maydis (IS) entre os estádios 8 e 9 em cada experimento, de acordo com o seguinte modelo:

$$
Y_{i j k}=\mu+D_{i}+G_{j}+B_{k}+D G_{i j}+\varepsilon_{i j k}
$$

em que onde $Y_{i j k}$ é o valor da variável resposta correspondente à dose $i(\mathrm{i}=0 ; 60 ; 120$; 180 ou $240 \mathrm{~kg} / \mathrm{ha}$ de nitrogênio), genótipo $j(\mathrm{j}=1,2,3,4$ ou 5) (Tabela 3) e bloco $k$ ( $\mathrm{k}=1,2$ ou 3); $\mu$ é a média geral da variável $Y ; D_{i}, G_{j}$ e $B_{k}$ os efeitos da dose $i$, no genótipo $j$, no bloco $k$, respectivamete; $D G i j$ o efeito da interação entre a dose $i$ e o genótipo $j ; \varepsilon_{i j k} \mathrm{o}$ erro aleatório associado à observação $Y_{i j k}$.

Tabela 4. Causas de variação e graus de liberdade na análise de variância utilizada.

\begin{tabular}{cc}
\hline Fonte de variação & Graus de liberdade \\
\hline Blocos & 2 \\
Genótipos (G) & 4 \\
Doses de nitrogênio (D) & 4 \\
Interação entre genótipos (G) e doses de nitrogênio (D) & 16 \\
Resíduo & 48 \\
Total & 74 \\
\hline
\end{tabular}

Foram calculadas correlações entre as variáveis rendimento e massa de grãos, rendimento e índice de severidade, teor de clorofila e índice de severidade. Para as variáveis onde o efeito de dose de nitrogênio foi significativo, foram ajustados modelos de regressão para quantificar o efeito do nitrogênio sobre as variáveis resposta, em cada um dos genótipos. A significância dos parâmetros dos modelos de regressão foi avaliada pelo teste t para contrastes.

Para avaliar o efeito de ambiente e as interações devido ao efeito de tratamentos (genótipo x doses de nitrogênio), foi realizada análise conjunta dos quatro experimentos, onde foi possível calcular as estimativas dos efeitos da interação, relativas às médias do rendimento de grãos para cada combinação de fatores. 
As análises de variância, correlação e regressão foram feitas utilizando os procedimentos GLM, CORR e MIXED do SAS (Statistical Analysis System), respectivamente.

Para levar em consideração o efeito do ambiente, utilizou-se o seguinte modelo:

$$
Y_{\text {tak }}=\mu+T_{t}+a_{a}+B_{a k}+(T a)_{t a}+\bar{e}_{t a k}
$$

em que $\boldsymbol{Y}_{\text {tak }}$ se refere à média observada correspondente à variável Y; $\mu$ à média geral referente à mesma variável; $\boldsymbol{T}_{\boldsymbol{t}}$ ao efeito do $\boldsymbol{t}$-ésimo tratamento; $\boldsymbol{B}_{\boldsymbol{a} \boldsymbol{k}}$ ao efeito do $\boldsymbol{k}$-ésimo bloco dentro do a-ésimo ambiente; $\boldsymbol{a}_{a}$ ao efeito do $\boldsymbol{a}$-ésimo ambiente; $(\boldsymbol{T a})_{t a}$ à interação do $\boldsymbol{t}$-ésimo tratamento com o a-ésimo ambiente, e $\overline{\boldsymbol{e}}_{\text {tak }}$ ao erro experimental associado à média $\boldsymbol{Y}_{\text {tak }}$ correspondente ao $\boldsymbol{t}$-ésimo tratamento (combinação do j-ésimo genótipo com a i-ésima dose de nitrogênio) no a-ésimo ambiente. Os valores das estimativas dos efeitos principais foram estimados pelas seguintes expressões:

$$
\begin{aligned}
\hat{G}_{t} & =\ddot{Y}_{t .}-Y_{. .} \\
\hat{a}_{a} & =\ddot{Y}_{. a}-Y_{. .}
\end{aligned}
$$

em que $\ddot{\boldsymbol{Y}}_{t}$ se refere ao valor da média observada correspondente ao $\boldsymbol{t}$-ésimo tratamento nos 4 ambientes (média de 3 repetições por ambiente); $\ddot{Y}_{. a}$ ao valor da média observada no a-ésimo ambiente, e $Y$.. à média geral.

A estimativa dos efeitos da interação para cada combinação de tratamentos é dada pela seguinte expressão:

$$
\hat{T} \hat{a}_{t a}=Y_{t}-\ddot{Y}_{t .}-\ddot{Y}_{. a}-Y_{. .}
$$

\subsection{Caracterização dos solos utilizados}

As análises das propriedades físicas e químicas do solo (Tabela 5) foram realizadas no Laboratório de Análise de Solos e Plantas do Departamento de Solos e Nutrição de Plantas (Escola Superior de Agricultura "Luiz de Queiroz", Universidade de São Paulo). 
Tabela 5. Resultado das análises químicas de solo das duas localidades estudadas.

\begin{tabular}{|c|c|c|c|c|c|c|c|c|c|c|c|c|c|}
\hline \multirow{2}{*}{ Local } & \multirow{2}{*}{ Solo } & \multirow{2}{*}{$\begin{array}{c}\mathrm{pH} \\
\mathrm{CaCl}_{2}\end{array}$} & \multirow{2}{*}{$\begin{array}{l}\mathrm{MO} \\
\mathrm{g} / \mathrm{dm}^{3}\end{array}$} & \multirow{2}{*}{\multicolumn{2}{|c|}{$\mathrm{mg} / \mathrm{dm}^{3}$}} & K & $\mathrm{Ca}$ & $\mathrm{Mg}$ & $\mathrm{Al}$ & $\mathrm{H}+\mathrm{Al}$ & SB & $\mathrm{T}$ & V \\
\hline & & & & & & \multicolumn{7}{|c|}{$\mathrm{mmol}_{\mathrm{c}} / \mathrm{dm}^{3}$} & $\%$ \\
\hline 1 & Solo 1 & 5,2 & 25 & 24 & 41 & 4,8 & 48 & 17 & 0 & 31 & 69,9 & 100,8 & 69 \\
\hline 2 & Solo 2 & 5,1 & 21 & 37 & - & 2,3 & 29 & 14 & - & 20 & 45,3 & 65,3 & 69 \\
\hline
\end{tabular}

Fonte: Laboratório de Análise de Solos e Plantas do Departamento de Solos e Nutrição de Plantas (Escola Superior de Agricultura "Luiz de Queiroz"

O solo utilizado no local 1 é classificado como uma Terra Roxa estruturada eutrófica (Solo 1: Campus "Luiz de Queiroz", Departamento de Produção Vegetal, Escola Superior de Agricultura “Luiz de Queiroz”, Universidade de São Paulo), textura argilosa/muito argilosa. O solo utilizado no local 2 é classificado como Latossolo Vermelho Amarelo (Solo 2: Estação Experimental de Anhembi, Departamento de Genética, Escola Superior de Agricultura "Luiz de Queiroz", Universidade de São Paulo), textura arenosa (72\% areia, 20\% argila) (Vidal Torrado \& Sparovek, 1993).

\subsection{Técnicas culturais}

O preparo do solo constituiu-se de cultivo mínimo, através de escarificação e gradagem, às vésperas da semeadura dos experimentos.

As aplicações de adubos na semeadura foram feitas manualmente nos sulcos, espaçados de $0,75 \mathrm{~m}$ (local 1) e 0,80m (local 2) entre si, abertos com sulcador tracionado por trator.

A adubação básica mineral, para todos os tratamentos, foi feita de acordo com os resultados das referidas análises químicas do solo e o rendimento almejado.

A adubação nitrogenada obedeceu a seguinte recomendação: (i) $30 \%$ na semeadura e o restante entre os estádios fenológicos 1 e 2 (5 a 6 folhas) para o local 1; (ii) $30 \%$ na semeadura, $40 \%$ no estádio fenológico 1 (4 folhas) e 30\% no estádio fenológico 2 (8 folhas) para o local 2 (Fancelli \& Dourado-Neto, 1997).

A semeadura foi realizada manualmente, nas referidas épocas, dispondo-se duas sementes a cada $0,19 \mathrm{~m}$ de espaçamento na linha de $4 \mathrm{~m}$ de comprimento, que por ocasião da terceira folha completamente desdobrada, realizou-se o desbaste, deixando-se quarenta e duas plantas em cada parcela experimental (seis linhas de $4 \mathrm{~m}$ de comprimento) utilizando a população máxima para os materiais genéticos relacionados. 
O tratamento de sementes foi efetuado para todos os genótipos em todos os experimentos, como forma de prevenção contra o ataque das principais pragas iniciais da cultura, bem como para o fornecimento de elementos essenciais (zinco e boro).

O controle de plantas daninhas foi efetuado com herbicida em pré-emergência.

\subsection{Determinações}

\subsubsection{Fenologia}

Durante o ciclo da cultura, para cada experimento, foram avaliados os estádios fenológicos para a caracterização das fases vegetativa (emergência ao florescimento) e reprodutiva (florescimento ao ponto de maturidade fisiológica) (Fancelli \& DouradoNeto, 1996).

\subsubsection{Graus-dia e desenvolvimento relativo da cultura}

Para obtenção do número de graus-dia (GD) (ou soma calórica) até o n-ésimo dia após a emergência, foi utilizada a seguinte equação:

$$
\left.G D_{n}=\sum_{i=1}^{n}\left(\frac{T_{\min _{i}}+T_{\text {max }_{i}} \cdot}{2}-T_{b}\right)\right)\left(\operatorname{se} \operatorname{Tmín}_{\mathrm{i}} \geq \mathrm{T}_{\mathrm{b}} \text { e Tmáx } \mathrm{i} \leq \mathrm{T}_{\mathrm{m}}\right)
$$

em que $\mathrm{n}$ se refere ao número de dias após a emergência referente ao florescimento (estádio 5), $\mathrm{T}_{\mathrm{b}}$ e $\mathrm{T}_{\mathrm{m}}$ às temperaturas basais mínima $\left(10^{\circ} \mathrm{C}\right)$ e máxima $\left(35^{\circ} \mathrm{C}\right)$, respectivamente, da cultura de milho; $\operatorname{Tm}^{\prime} n_{\mathrm{i}}$ e Tmáx $\mathrm{x}_{\mathrm{i}}$ às temperaturas mínima e máxima do ar, respectivamente, no i-ésimo dia após a emergência.

O desenvolvimento relativo foi determinado durante todo o ciclo da cultura, onde foi verificada a sua correspondência com os estádios fenológicos. A soma calórica até o florescimento foi determinada utilizando dados diários (Experimentos 1 e 2):

$$
D r_{m}=\frac{\sum_{i=1}^{m} \frac{T_{\text {min }_{i}}+T_{\text {máx }_{i}}}{2}-T b}{G D_{p m f}}
$$

em que $m$ se refere ao número de dias após a emergência até o ponto de maturidade fisiológica, $\operatorname{Dr}_{\mathrm{m}}$ ao desenvolvimento relativo da cultura no m-ésimo dia após a 
emergência, $G D_{p m f}$ ao número de graus-dia referente ao ponto de maturidade fisiológica ( $\left.{ }^{\circ} \mathrm{C} \cdot \mathrm{dia}\right)$.

\subsubsection{Parâmetros fitotécnicos}

Os seguintes parâmetros fitotécnicos foram determinados: (i) índice de área foliar $\left(\mathrm{m}^{2} / \mathrm{m}^{2}\right)$; (ii) altura da planta (cm); (iii) altura de inserção da espiga (cm); (iv) comprimento do primeiro internódio (mm); (v) diâmetro do colmo (mm); (vi) prolificidade (número médio de espigas por planta); (vii) comprimento da espiga $(\mathrm{cm})$; (viii) diâmetro do sabugo (cm); (ix) número de fileiras por espiga; (x) número de grãos por fileira; (xi) rendimento de grãos medido na parcela ( $\mathrm{kg} / \mathrm{ha})$; (xii) estande no ponto de maturidade fisiológica (estádio 10) (plantas/ha); (xiii) massa de 1.000 grãos (g); (xiv) diâmetro da espiga (cm); (xv) leitura SPAD para estimar o teor de clorofila na folha; (xvi) índice de severidade referente à doença causada por P. maydis (Tabela 6).

\subsubsection{Procedimento de determinação do índice de área foliar}

A área foliar total média da planta $\left(\mathrm{AFT}_{\mathrm{j}}, \mathrm{cm}^{2}\right)$ do $\mathrm{j}$-ésimo tratamento foi determinada através do cálculo da superfície da área foliar de três plantas por parcela, mediante o uso da seguinte expressão matemática:

$$
A F T_{j}=0,75 \frac{\sum_{k=1}^{3} \sum_{i=1}^{n f k} C_{i, k, j} \cdot L_{i, k, j}}{3}
$$

em que $\mathrm{n}_{\mathrm{fk}}$ se refere ao número total de folhas, $\mathrm{C}_{\mathrm{i}, \mathrm{j}, \mathrm{k}}$ ao comprimento $(\mathrm{cm})$ e $\mathrm{L}_{\mathrm{i}, \mathrm{j}}$ à largura (cm) máxima da i-ésima folha da k-ésima planta do j-ésimo tratamento (Francis et al., 1969).

Sendo assim, o índice de área foliar referente ao j-ésimo tratamento (IAFj, $\mathrm{m}^{2} / \mathrm{m}^{2}$ ) foi obtido pela seguinte expressão:

$$
\mathrm{IAF}_{\mathrm{j}}=\frac{\mathrm{AFT}_{\mathrm{j}}}{e_{1} \cdot e_{2}}
$$

em que $e_{1}$ e $e_{2}$ se referem ao espaçamento (cm) entre plantas (na fileira) e entre fileiras de plantas, respectivamente. 
Tabela 6. Descrição sumária das parâmetros fitotécnicos determinados nos experimentos em função do número de avaliações $(\mathrm{N})$ nos diferentes estádios fenológicos.

\begin{tabular}{cccccccccc}
\hline \multirow{2}{*}{ Variável } & \multirow{2}{*}{ Parâmetro $^{1}$} & \multicolumn{2}{c}{ Experimento 1 } & \multicolumn{2}{c}{ Experimento 2 } & \multicolumn{2}{c}{ Experimento 3 } & \multicolumn{2}{c}{ Experimento 4 } \\
\cline { 3 - 9 } & & $\mathrm{N}$ & Estádio & $\mathrm{N}$ & Estádio & $\mathrm{N}$ & Estádio & $\mathrm{N}$ & Estádio \\
\hline 1 & $\mathrm{IAF}$ & 3 & $3 / 5 / 8$ & 3 & $3 / 5 / 7$ & 5 & $3 / 5 / 6 / 7 / 8$ & 5 & $3 / 5 / 6 / 7$ \\
2 & $\mathrm{AP}$ & 1 & 10 & 1 & 10 & 1 & 10 & 1 & 10 \\
3 & $\mathrm{AE}$ & 1 & 10 & 1 & 10 & 1 & 10 & 1 & 10 \\
4 & $\mathrm{Ci1}$ & 5 & $3 / 5 / 6 / 7 / 8$ & 5 & $3 / 5 / 6 / 7 / 8$ & 5 & $7 / 8$ & 2 & $7 / 8$ \\
5 & $\mathrm{Dc}$ & 5 & $3 / 5 / 6 / 7 / 8$ & 5 & $3 / 5 / 6 / 7 / 8$ & 5 & $7 / 8$ & 2 & $7 / 8$ \\
6 & $\mathrm{Pr}$ & 1 & $\mathrm{C}$ & 1 & $\mathrm{C}$ & 1 & $\mathrm{C}$ & 1 & $\mathrm{C}$ \\
7 & $\mathrm{CE}$ & 1 & $\mathrm{C}$ & 1 & $\mathrm{C}$ & 1 & $\mathrm{C}$ & 1 & $\mathrm{C}$ \\
8 & $\mathrm{DE}$ & 1 & $\mathrm{C}$ & 1 & $\mathrm{C}$ & 1 & $\mathrm{C}$ & 1 & $\mathrm{C}$ \\
9 & $\mathrm{Ds}$ & 1 & $\mathrm{C}$ & 1 & $\mathrm{C}$ & 1 & $\mathrm{C}$ & 1 & $\mathrm{C}$ \\
10 & $\mathrm{NF}$ & 1 & $\mathrm{C}$ & 1 & $\mathrm{C}$ & 1 & $\mathrm{C}$ & 1 & $\mathrm{C}$ \\
11 & $\mathrm{NGF}$ & 1 & $\mathrm{C}$ & 1 & $\mathrm{C}$ & 1 & $\mathrm{C}$ & 1 & $\mathrm{C}$ \\
12 & $\mathrm{R}$ & 1 & $\mathrm{C}$ & 1 & $\mathrm{C}$ & 1 & $\mathrm{C}$ & 1 & $\mathrm{C}$ \\
13 & $\mathrm{Est}$ & 1 & 10 & 1 & 10 & 1 & 10 & 1 & 10 \\
14 & $\mathrm{M} 1000$ & 1 & $\mathrm{C}$ & 1 & $\mathrm{C}$ & 1 & $\mathrm{C}$ & 1 & $\mathrm{C}$ \\
15 & $\mathrm{TC}$ & 5 & $3 / 5 / 6 / 7 / 8$ & 5 & $3 / 5 / 6 / 7 / 8$ & 5 & $3 / 5 / 6 / 7 / 8$ & 5 & $3 / 5 / 6 / 7 / 8$ \\
16 & $\mathrm{IS}$ & 1 & 9 & 1 & 9 & 3 & $5 / 6 / 8$ & 3 & $5 / 7 / 8$ \\
\hline
\end{tabular}

1 IAF: índice de área foliar $\left(\mathrm{m}^{2} / \mathrm{m}^{2}\right)$; AP: altura da planta $(\mathrm{cm})$; AE: altura de inserção da espiga $(\mathrm{cm})$; Ci1: comprimento do primeiro internódio $(\mathrm{mm})$; Dc: diâmetro do colmo $(\mathrm{mm})$; Pr: prolificidade (número médio de espigas por planta); CE: comprimento da espiga $(\mathrm{cm})$; DE: diâmetro da espiga $(\mathrm{cm})$; Ds: diâmetro do sabugo $(\mathrm{cm})$; NF: número de fileiras por espiga; NGF: número de grãos por fileira; R: rendimento de grãos medido na parcela $(\mathrm{kg} / \mathrm{ha})$; Est: estande no ponto de maturidade fisiológica (estádio 10) (plantas/ha); $\mathbf{M}_{1000}$ : massa de 1.000 grãos (g); TC: leitura SPAD para estimar o teor de clorofila na folha; IS: índice de severidade referente à doença causada por $P$. maydis 2 C: colheita

\subsubsection{Procedimentos de determinação dos componentes de produção}

Os componentes de produção avaliados foram: (i) altura de planta e de inserção de espiga: foram amostradas dez plantas por parcela no estádio 10 (ponto de maturidade fisiológica); (ii) comprimento do primeiro internódio e diâmetro do colmo: foram amostradas três plantas por parcela em diversas épocas; (iii) prolificidade: o número de espigas por planta foi determinado pela razão entre número de espigas colhidas pelo número total de plantas presentes na área útil da parcela no final do ciclo; (iv) comprimento e diâmetro de espigas: foram determinados em dez espigas por parcela 
amostradas aleatoriamente; (v) diâmetro de sabugo, número de fileiras por espiga e número de grãos por fileira: para determinação desses parâmetros, foram coletadas cinco espigas por parcela; (vi) estande: o número total de plantas por parcela foi determinado no estádio 10 (ponto de maturidade fisiológica); (vii) rendimento de grãos: foi mensurada a massa total de grãos na área útil da parcela ( $\mathrm{kg} /$ parcela) nas duas linhas centrais de $4 \mathrm{~m}$ de comprimento (Figura 2). O rendimento foi convertido em $\mathrm{kg} / \mathrm{ha}$, para o teor de água no grão de $13 \%$. A determinação da umidade do grão foi feita imediatamente após a debulha manual de todas as espigas da parcela utilizando o método padrão de estufa (Brasil, 1992); e (viii) massa de 1.000 grãos: foi feita a determinação através da pesagem de 8 amostras de 100 sementes corrigida para $13 \%$ de umidade, conforme preconizado por Brasil (1992) (método da massa de 1.000 sementes) (Tabela 6).

\subsubsection{Procedimento de determinação do teor de clorofila total}

Utilizando-se de um medidor portátil (modelo STAF-502, marca Minolta), foi determinada, em todos os experimentos, a leitura SPAD para estimar o teor de clorofila total em cinco avaliações em diferentes estádios fenológicos de desenvolvimento (3, 5, 6, 7 e 8), onde foram feitas 3 medidas em cada uma das dez plantas de cada parcela (Figura 2).

\subsubsection{Procedimento de determinação do índice de severidade da doença causada por Phaeosphaeria maydis}

Para avaliação dos diferentes genótipos utilizados quanto à resistência ou susceptibilidade à doença causada por $P$. maydis, foram feitas avaliações em todos os experimentos com a finalidade de se estimar a porcentagem de área foliar afetada devido à incidência e severidade da referida doença.

Foi adotada a metodologia preconizada por Pacola-Meirelles et al. (1998), a qual utiliza uma escala diagramática de notas que variam de 1 a 9 , conforme maior ou menor porcentagem de área foliar lesionada em folhas de milho. A nota 1 indica resistência (ou seja, menos de $1 \%$ de área foliar com lesões). A nota 9 indica alta susceptibilidade à 
doença (ou seja, uma variação de 80 a 100\% de área foliar lesionada). A nota foi adotada como índice de severidade (IS) da doença causada por Phaeosphaeria maydis.

Em cada experimento, a primeira avaliação visual teve o seu início sempre que fora constatada a presença dos primeiros sintomas de incidência do fungo patogênico. Em cada avaliação, que variou em número de um a três, foram utilizados pelo menos dois avaliadores com o intuito de minimizar a subjetividade do procedimento adotado, obedecendo sempre um intervalo máximo de 15 dias entre avaliações, conforme o nível de severidade da doença observado.

Em cada parcela foram avaliadas dez plantas em cada uma das duas linhas centrais da área útil, totalizando vinte plantas por parcela.

Para assegurar um maior efeito do potencial de inócuo já existente no local dos ensaios, foram utilizados genótipos susceptíveis à doença semeados em bordadura, $15 \mathrm{a}$ 20 dias antes da semeadura do experimento definitivo. 


\section{RESULTADOS E DISCUSSÃO}

\subsection{Dados meteorológicos}

Os valores médios mensais das observações (temperatura do ar, umidade relativa, radiação solar e chuva) estão resumidos na Tabela 30 (ANEXO A).

Por problemas operacionais, parte dos dados referente ao local 2 (Experimentos 3 e 4) não foi registrada. Para que se possa ser feita uma caracterização do clima local, deverá ser levado em conta o efeito comparativo dos dados da localidade 1. Nesse sentido, algumas considerações devem ser estabelecidas, com o precedente de que haja diferença entre as condições climáticas do local 1 para o local 2.

O fato a ser considerado é que a localidade 2 (Estação Experimental de Anhembi) está situada às margens do rio Tietê, distanciando-se $56 \mathrm{~km}$ ao sul da localidade 1 , sendo observada uma altitude mais baixa no local com temperaturas médias mais elevadas. $\mathrm{O}$ prolongamento dessas temperaturas durante o período noturno pode ser devido ao efeito provocado pela menor altitude associada à proximidade do leito do rio, onde a umidade relativa do ar local acaba permanecendo maior por um período mais longo no ambiente (efeito de microclima), o que favorece períodos de permanência de temperaturas mais altas durante o dia, estendendo-se durante a noite.

A ocorrência de temperaturas médias elevadas, o prolongamento dos períodos com elevada taxa de umidade relativa do ar e principalmente, a ocorrência e a permanência do ponto de orvalho por um longo período durante o amanhecer, favorecem diretamente o desenvolvimento de doenças, sem contar evidentemente, com a presença do patógeno (Silva \& Menten, 1997). 


\subsection{Fenologia e graus-dia}

Fenologia é definida como sendo o estudo dos eventos periódicos que ocorrem durante as fases vegetativa e reprodutiva da planta em função da sua reação às condições de ambiente. No intuito de extrapolar resultados, principalmente para fins de manejo, correlaciona-se a caracterização morfológica da planta, ao longo de todo o seu ciclo, com as mudanças induzidas por alterações fisiológicas. Como fundamento filosófico, a caracterização dos estádios fenológicos pode auxiliar na identificação dessas alterações fisiológicas da planta através das mudanças em sua morfologia.

A fenologia determinada no presente trabalho é referente às parcelas dos tratamentos (cinco genótipos) na dose de $120 \mathrm{~kg} / \mathrm{ha}$ de nitrogênio (bloco III), nos quatro experimentos (Tabela 7). $\mathrm{O}$ estádio 5 (florescimento geral) foi determinado em todas as parcelas para todos os experimentos (Tabela 8).

Para todos os genótipos e em todos os experimentos, há uma tendência de redução da fase vegetativa (período entre a emergência e o florescimento) com o aumento da dose de nitrogênio, bem como com o atraso da época de semeadura.

De acordo com Berger (1962) e Fancelli \& Dourado-Neto (1997), temperaturas médias diárias elevadas durante o crescimento e desenvolvimento das plantas podem antecipar o estádio 5 (florescimento), principalmente se estiverem associadas a uma inadequada disponibilidade de água no solo e à radiação solar. Nas diferentes épocas de semeadura, a redução da fase vegetativa ocorreu devido ao aumento das temperaturas médias observadas. 
Tabela 7. Correspondência do número de dias após a emergência com a fenologia referente aos cinco genótipos, nos quatro experimentos (E), especificando a data de semeadura, número de folhas ( $\left.\begin{array}{lllll}1 & F & \text { a } & 12 & F\end{array}\right)$, número de dias após a emergência (DAE) para o florescimento e graus-dia $\left(G D_{f l},{ }^{\circ} \mathrm{C} . \operatorname{dia}\right)$.

\begin{tabular}{|c|c|c|c|c|c|c|c|c|c|c|c|c|c|c|c|c|c|c|c|c|c|c|c|}
\hline \multirow{3}{*}{ Genótipo } & \multirow{3}{*}{$\mathrm{E}$} & \multirow{3}{*}{ Semeadura } & \multicolumn{20}{|c|}{ Estádio Fenológico $^{2}$} & \multirow{3}{*}{$\begin{array}{l}G D_{f l}{ }^{3} \\
{ }^{\circ} \mathrm{C} . d i a\end{array}$} \\
\hline & & & \multicolumn{4}{|l|}{0} & \multicolumn{4}{|l|}{1} & \multicolumn{4}{|l|}{2} & \multirow{2}{*}{$\frac{3}{12 F}$} & \multirow{2}{*}{$\begin{array}{l}4 \\
P\end{array}$} & \multirow{2}{*}{$\begin{array}{c}5 \\
\mathrm{Fl}\end{array}$} & \multirow{2}{*}{$\begin{array}{c}6 \\
\text { GL }\end{array}$} & \multirow{2}{*}{$\begin{array}{c}7 \\
\text { GP }\end{array}$} & \multirow{2}{*}{$\begin{array}{c}8 \\
\mathrm{GF}\end{array}$} & \multirow{2}{*}{$\begin{array}{c}9 \\
\text { GD }\end{array}$} & \multirow{2}{*}{$\begin{array}{c}10 \\
\mathrm{PMF}\end{array}$} & \\
\hline & & & $E^{1}$ & $1 F$ & $2 F$ & $3 F$ & $4 F$ & $5 F$ & $6 F$ & $7 F$ & $8 F$ & $9 F$ & $10 F$ & $11 \mathrm{~F}$ & & & & & & & & & \\
\hline \multirow{4}{*}{ P-30F45 } & 1 & $11 / 09 / 00$ & 7 & 7 & 11 & 15 & 19 & 24 & 28 & 32 & 35 & 38 & 40 & 43 & 46 & 58 & 61 & 73 & 85 & 97 & 109 & 116 & 832 \\
\hline & 2 & $29 / 11 / 00$ & 6 & 4 & 7 & 10 & 15 & 19 & 23 & 27 & 32 & 35 & 42 & 46 & 49 & 52 & 54 & 66 & 78 & 90 & 102 & 109 & 847 \\
\hline & 3 & $27 / 12 / 00$ & 5 & 6 & 10 & 13 & 16 & 20 & 24 & 27 & 31 & 34 & 36 & 39 & 42 & 50 & 55 & 67 & 79 & 91 & 103 & 110 & \\
\hline & 4 & $22 / 2 / 01$ & 6 & 4 & 7 & 10 & 13 & 16 & 20 & 25 & 29 & 33 & 36 & 39 & 42 & 49 & 53 & 65 & 77 & 89 & 101 & 108 & \\
\hline \multirow{4}{*}{ C-333B } & 1 & $11 / 09 / 00$ & 7 & 7 & 11 & 15 & 18 & 22 & 26 & 29 & 32 & 35 & 38 & 42 & 45 & 60 & 64 & 76 & 88 & 100 & 112 & 119 & 880 \\
\hline & 2 & $29 / 11 / 00$ & 6 & 4 & 6 & 9 & 13 & 18 & 22 & 25 & 30 & 33 & 38 & 41 & 44 & 57 & 59 & 71 & 83 & 95 & 107 & 114 & 930 \\
\hline & 3 & $27 / 12 / 00$ & 5 & 5 & 8 & 11 & 13 & 17 & 20 & 24 & 27 & 31 & 34 & 36 & 39 & 50 & 55 & 67 & 79 & 91 & 103 & 110 & \\
\hline & 4 & $22 / 02 / 01$ & 6 & 5 & 7 & 10 & 13 & 16 & 18 & 22 & 26 & 31 & 34 & 37 & 40 & 50 & 56 & 68 & 80 & 92 & 104 & 111 & \\
\hline \multirow{4}{*}{ P-30K75 } & 1 & $11 / 09 / 00$ & 7 & 7 & 11 & 15 & 18 & 22 & 26 & 30 & 34 & 37 & 40 & 43 & 46 & 54 & 59 & 71 & 83 & 95 & 107 & 114 & 821 \\
\hline & 2 & $29 / 11 / 00$ & 6 & 4 & 7 & 10 & 14 & 18 & 22 & 27 & 30 & 34 & 39 & 43 & 46 & 50 & 54 & 66 & 78 & 90 & 102 & 109 & 816 \\
\hline & 3 & $27 / 12 / 00$ & 5 & 5 & 9 & 12 & 14 & 17 & 20 & 25 & 28 & 32 & 34 & 37 & 40 & 48 & 52 & 64 & 76 & 88 & 100 & 107 & \\
\hline & 4 & $22 / 02 / 01$ & 6 & 5 & 7 & 10 & 13 & 17 & 20 & 24 & 28 & 31 & 34 & 37 & 40 & 47 & 53 & 65 & 77 & 89 & 101 & 108 & \\
\hline \multirow{4}{*}{ CO-9560 } & 1 & $11 / 09 / 00$ & 7 & 7 & 11 & 15 & 19 & 23 & 27 & 31 & 34 & 38 & 41 & 44 & 46 & 57 & 61 & 73 & 85 & 97 & 109 & 116 & 821 \\
\hline & 2 & $29 / 11 / 00$ & 6 & 4 & 7 & 10 & 14 & 18 & 22 & 27 & 30 & 35 & 42 & 45 & 47 & 52 & 55 & 67 & 79 & 91 & 103 & 110 & 831 \\
\hline & 3 & $27 / 12 / 00$ & 5 & 5 & 8 & 11 & 14 & 17 & 21 & 25 & 29 & 32 & 35 & 38 & 41 & 49 & 53 & 65 & 77 & 89 & 101 & 108 & \\
\hline & 4 & $22 / 02 / 01$ & 6 & 4 & 6 & 9 & 13 & 16 & 20 & 24 & 28 & 32 & 35 & 38 & 41 & 48 & 52 & 64 & 76 & 88 & 100 & 107 & \\
\hline \multirow{4}{*}{ C-909 } & 1 & $11 / 09 / 00$ & 7 & 7 & 12 & 16 & 20 & 24 & 29 & 32 & 36 & 39 & 42 & 45 & 49 & 55 & 60 & 72 & 84 & 96 & 108 & 115 & 821 \\
\hline & 2 & $29 / 11 / 00$ & 6 & 4 & 7 & 10 & 14 & 19 & 24 & 28 & 32 & 37 & 43 & 46 & 48 & 52 & 56 & 68 & 80 & 92 & 104 & 111 & 831 \\
\hline & 3 & $27 / 12 / 00$ & 5 & 5 & 8 & 12 & 15 & 19 & 23 & 27 & 31 & 34 & 37 & 40 & 42 & 48 & 53 & 65 & 77 & 89 & 101 & 108 & \\
\hline & 4 & $22 / 02 / 01$ & 6 & 4 & 7 & 10 & 14 & 18 & 22 & 26 & 30 & 34 & 37 & 40 & 43 & 49 & 53 & 65 & 77 & 89 & 101 & 108 & \\
\hline
\end{tabular}

1 DAE: Dias após a semeadura (até a emergência).

2 Fenologia referente aos tratamentos dos cinco genótipos na dose de $120 \mathrm{~kg} /$ ha de nitrogênio (bloco III) nos quatro experimentos.

$3 \mathrm{GD}_{\mathrm{fl}}$ calculado em função da média do florescimento geral (Tabela 8) de tratamentos (15 observações) para cada genótipo, nos respectivos experimentos. 
Tabela 8. Número de dias após a emergência (DAE) para o florescimento geral e para o ponto de maturidade fisiológica referente aos cinco genótipos nos quatro experimentos (média de 3 repetições).

\begin{tabular}{|c|c|c|c|c|c|c|c|c|c|c|c|c|c|}
\hline \multirow{3}{*}{ Genótipo } & \multirow{3}{*}{ Experimento } & \multicolumn{6}{|c|}{ Florescimento (DAE) } & \multicolumn{6}{|c|}{ Ponto de Maturidade Fisiológica (DAE) } \\
\hline & & \multicolumn{5}{|c|}{ Doses $(\mathrm{kg} / \mathrm{ha} \mathrm{N})$} & \multirow{2}{*}{ Média } & \multicolumn{5}{|c|}{ Doses $(\mathrm{kg} / \mathrm{ha} \mathrm{N})$} & \multirow{2}{*}{ Média } \\
\hline & & 0 & 60 & 120 & 180 & 240 & & 0 & 60 & 120 & 180 & 240 & \\
\hline \multirow{4}{*}{ P-30F 45} & 1 & 67 & 62 & 60 & 60 & 59 & 62 & 122 & 117 & 115 & 115 & 114 & 117 \\
\hline & 2 & 64 & 58 & 56 & 55 & 54 & 58 & 119 & 113 & 111 & 110 & 109 & 113 \\
\hline & 3 & 65 & 56 & 54 & 54 & 53 & 56 & 120 & 111 & 109 & 109 & 109 & 111 \\
\hline & 4 & 57 & 56 & 54 & 54 & 52 & 55 & 112 & 111 & 109 & 109 & 107 & 110 \\
\hline \multirow{4}{*}{ C-333B } & 1 & 72 & 66 & 64 & 62 & 61 & 65 & 127 & 121 & 119 & 117 & 116 & 120 \\
\hline & 2 & 72 & 62 & 61 & 58 & 58 & 62 & 127 & 117 & 116 & 113 & 113 & 117 \\
\hline & 3 & 67 & 58 & 56 & 54 & 54 & 58 & 122 & 113 & 111 & 109 & 109 & 113 \\
\hline & 4 & 59 & 57 & 56 & 56 & 56 & 57 & 114 & 112 & 111 & 111 & 111 & 112 \\
\hline \multirow{4}{*}{ P-30K75 } & 1 & 65 & 59 & 58 & 58 & 57 & 59 & 120 & 114 & 113 & 113 & 112 & 114 \\
\hline & 2 & 60 & 56 & 54 & 54 & 54 & 56 & 115 & 111 & 109 & 109 & 109 & 111 \\
\hline & 3 & 60 & 54 & 53 & 52 & 52 & 54 & 115 & 109 & 108 & 107 & 107 & 109 \\
\hline & 4 & 57 & 52 & 51 & 52 & 51 & 53 & 112 & 107 & 106 & 107 & 106 & 108 \\
\hline \multirow{4}{*}{ CO-9560 } & 1 & 68 & 61 & 59 & 58 & 58 & 61 & 123 & 116 & 114 & 113 & 113 & 116 \\
\hline & 2 & 62 & 56 & 55 & 54 & 54 & 56 & 117 & 111 & 110 & 109 & 109 & 111 \\
\hline & 3 & 59 & 54 & 53 & 53 & 53 & 54 & 114 & 109 & 108 & 108 & 108 & 109 \\
\hline & 4 & 56 & 52 & 51 & 53 & 51 & 53 & 111 & 107 & 106 & 108 & 106 & 108 \\
\hline \multirow{4}{*}{ C-909 } & 1 & 67 & 60 & 58 & 57 & 57 & 60 & 122 & 115 & 113 & 112 & 112 & 115 \\
\hline & 2 & 60 & 56 & 55 & 54 & 54 & 56 & 115 & 111 & 110 & 109 & 109 & 111 \\
\hline & 3 & 62 & 55 & 54 & 53 & 53 & 55 & 117 & 110 & 109 & 108 & 108 & 110 \\
\hline & 4 & 56 & 56 & 54 & 53 & 53 & 54 & 111 & 111 & 109 & 108 & 108 & 109 \\
\hline
\end{tabular}




\subsection{Parâmetros fitotécnicos}

\subsection{1 Índice de área foliar}

O índice de área foliar expressa a área foliar, em estudos de comunidades vegetais, agrícolas ou não. IAF é a relação entre a área foliar total da planta e a área de terreno (solo) disponível a ela. Dessa forma, esse índice depende diretamente da área foliar atingida, apresentando uma evolução em função do tempo.

Os valores referentes ao índice de área foliar dos quatro experimentos avaliados são apresentados na Tabela 9, Tabela 12, Tabela 15 e Tabela 18. Para todos os genótipos estudados, em função do crescimento e desenvolvimento da cultura, observou-se que ocorre um incremento máximo do índice de área foliar até aproximadamente o início do estádio 6 (grãos leitosos). Em seguida, em função do início do período de enchimento de grãos, ocorre um decréscimo gradativo devido à senescência das plantas, acentuando-se até o ponto de maturidade fisiológica. Se verificarmos a fase de enchimento de grãos (estádios 7 e 8), pode-se observar que com doses acima de $120 \mathrm{~kg} / \mathrm{ha}$ de nitrogênio, o índice de área foliar se mantém relativamente alto após florescimento (estádio 5), o que poderia contribuir significativamente para o suprimento de fotoassimilados durante a fase reprodutiva, influenciando diretamente no rendimento de grãos.

Nas diferentes doses estudadas, verificou-se que quanto maior for a adubação nitrogenada, maior será a área foliar. Em relação à testemunha (dose $0 \mathrm{~kg} / \mathrm{ha}$ de nitrogênio), observou-se que os índices apresentados praticamente duplicaram quando foram aplicadas doses elevadas de nitrogênio. Consequentemente, essa expansão contribuirá para o aumento do índice relacionado (Tabela 10, Tabela 13, Tabela 16 e Tabela 19). Ainda, na análise de regressão esse fato se confirma, pois em todos os experimentos, os genótipos apresentaram efeito quadrático para o fator dose (1 FV: Fonte de variação.

2 GL: Graus de liberdade.

3 Prob: Probabilidade a nível de 5\%.

Tabela 32, Tabela 34, Tabela 36, Tabela 38, ANEXO B).

Havendo pouca disponibilidade de nitrogênio no solo (dose $0 \mathrm{~kg} / \mathrm{ha}$ de nitrogênio), o índice apresentado é inferior àquele considerado ideal para a cultura, conforme citado por Andrade et al. (1991), que atribuem valores ao redor de 5 como o índice de área foliar ideal para a cultura de milho. Citam ainda, que tal índice pode sofrer uma variação entre 3 e 8 , em função do genótipo e do ambiente considerado. 
Nos experimentos 1 e 2, de maneira genérica, pôde-se observar que o genótipo de ciclo normal (C-333B) apresentou índices ligeiramente superiores em relação aos genótipos considerados de ciclo precoce e superprecoce, principalmente nas doses de mais elevadas de nitrogênio.

Tabela 9. Índice área foliar (IAF, $\mathrm{m}^{2} / \mathrm{m}^{2}$ ) (média de 3 repetições) avaliado em três diferentes épocas (experimento 1, data de semeadura: 11 de setembro de 2000, população: 70.000 plantas/ha).

\begin{tabular}{|c|c|c|c|c|}
\hline \multirow{2}{*}{ Genótipo } & \multirow{2}{*}{$\begin{array}{c}\text { Dose }^{1} \\
(\mathrm{~kg} / \mathrm{ha})\end{array}$} & \multicolumn{3}{|c|}{ Estádio Fenológico } \\
\hline & & $3-4\left(54 \mathrm{DAE}^{2}\right)$ & 5 (64 DAE) & 8-9 (107 DAE) \\
\hline \multirow{5}{*}{ P-30F45 } & 0 & 2,84 & 2,44 & 1,75 \\
\hline & 60 & 3,55 & 4,27 & 2,12 \\
\hline & 120 & 3,82 & 5,13 & 2,13 \\
\hline & 180 & 3,51 & 4,59 & 2,90 \\
\hline & 240 & 4,06 & 5,21 & 3,16 \\
\hline \multirow{5}{*}{ C-333B } & 0 & 2,32 & 2,72 & 2,24 \\
\hline & 60 & 3,64 & 4,96 & 2,77 \\
\hline & 120 & 3,65 & 4,92 & 2,74 \\
\hline & 180 & 4,25 & 5,29 & 3,45 \\
\hline & 240 & 4,40 & 6,11 & 3,89 \\
\hline \multirow{5}{*}{ P-30K 75} & 0 & 2,96 & 2,38 & 1,68 \\
\hline & 60 & 4,11 & 4,37 & 2,23 \\
\hline & 120 & 4,75 & 5,06 & 2,60 \\
\hline & 180 & 4,49 & 5,10 & 2,56 \\
\hline & 240 & 4,15 & 5,17 & 3,27 \\
\hline \multirow{5}{*}{$\mathrm{CO}-9560$} & 0 & 2,48 & 2,09 & 1,34 \\
\hline & 60 & 3,87 & 4,15 & 2,22 \\
\hline & 120 & 3,91 & 5,07 & 2,49 \\
\hline & 180 & 4,56 & 5,39 & 3,49 \\
\hline & 240 & 4,30 & 5,32 & 3,20 \\
\hline \multirow{5}{*}{ C-909 } & 0 & 2,10 & 1,95 & 1,35 \\
\hline & 60 & 4,42 & 3,74 & 1,91 \\
\hline & 120 & 3,69 & 4,80 & 2,15 \\
\hline & 180 & 4,72 & 5,11 & 3,00 \\
\hline & 240 & 4,15 & 4,81 & 3,14 \\
\hline
\end{tabular}

1 Dose: adubação nitrogenada ( $\mathrm{kg} / \mathrm{ha}$ de nitrogênio).

2 DAE: dias após a emergência. 
Na avaliação do estádio 5 (experimento 1), o referido genótipo 2 (C-333B) diferiu significativamente com os genótipos 4 e 5 (Tabela 33, ANEXO B), para os índices de área foliar. No experimento 2, o mesmo genótipo diferiu significativamente com todos os demais genótipos, em pelo menos uma das combinações (Tabela 35, ANEXO B).

No experimento 3, não foi verificada diferenças significativas entre os índices de área foliar, porém foi observada diferença entre o genótipo 2 e os genótipos 3 e 4; entre o genótipo 5 e os genótipos 1, 3 e 4, em pelo menos uma das combinações (Tabela 37, ANEXO B).

No experimento 4, o índice de área foliar do genótipo 2 (C-333B) diferiu significativamente dos genótipos 3 e 5 (Tabela 39, ANEXO B).

Através dos dados dos experimentos 3 e 4, pode-se confirmar a hipótese de que altas temperaturas contribuem significativamente para a redução da fase vegetativa, pois como foi observado no item fenologia, houve antecipação do florescimento geral, que diretamente afetou o índice de área foliar verificado para a fase (florescimento).

$\mathrm{O}$ estresse provocado pela inadequação do genótipo às condições ambientais ocasiona maior predisposição da planta a doenças (Fancelli \& Dourado-Neto, 1996). O fato pode ser observado ainda nos experimentos 3 e 4, para as médias dos índices de área foliar dos genótipos C-909 e P-30F45 (estádios 8 e 9), que foram ligeiramente inferiores aos demais. Além de apresentarem a referida inadequação para as épocas de semeadura utilizadas, correlacionaram com a baixa tolerância e alta susceptibilidade, respectivamente, à doença causada por P. maydis. Sendo assim, de maneira indicativa, observou-se que os menores índices máximos de área foliar resultaram em menores rendimentos de grãos. 
Tabela 10. Resumo da análise individual das médias de doses de nitrogênio para índice de área foliar $\left(\mathrm{m}^{2} / \mathrm{m}^{2}\right)$ (experimento 1, população de 70.000 plantas $/ \mathrm{ha}$ ), em três épocas de avaliação, com teste $\mathrm{F}$ para genótipos dentro de doses (média de 3 repetições).

\begin{tabular}{ccccccc}
\hline \multirow{2}{*}{$\begin{array}{c}\text { Dose } \\
(\mathrm{kg} / \mathrm{ha})\end{array}$} & \multicolumn{6}{c}{ Estádio Fenológico } \\
\cline { 2 - 7 } & \multicolumn{2}{c}{$3-4(54 \mathrm{DAE})$} & \multicolumn{2}{c}{$5(64 \mathrm{DAE})$} & \multicolumn{2}{c}{$8-9(107 \mathrm{DAE})$} \\
\cline { 2 - 6 } & Média & $\mathrm{F}^{1}$ & Média & $\mathrm{F}$ & Média & $\mathrm{F}$ \\
\hline 0 & 2,54 & $5,64^{*}$ & 2,32 & $2,99^{\mathrm{NS}}$ & 1,67 & $6,81^{*}$ \\
60 & 3,92 & $2,98^{\mathrm{NS}}$ & 4,30 & $9,23^{* *}$ & 2,25 & $2,58^{\mathrm{NS}}$ \\
120 & 3,97 & $12,10^{* *}$ & 4,99 & $0,15^{\mathrm{NS}}$ & 2,42 & $2,25^{\mathrm{NS}}$ \\
180 & 4,31 & $5,11^{*}$ & 5,10 & $1,32^{\mathrm{NS}}$ & 3,08 & $3,58^{\mathrm{NS}}$ \\
240 & 4,21 & $0,32^{\mathrm{NS}}$ & 5,32 & $6,65^{* *}$ & 3,33 & $6,04^{*}$ \\
\hline
\end{tabular}

1 Valor $\mathrm{F}$ com graus de liberdade 4 para genótipos (numerador) e 8 para resíduo (denominador)

Tabela 11. Resumo da análise de variância referente ao índice de área foliar $\left(\mathrm{m}^{2} / \mathrm{m}^{2}\right)$ (experimento 1, população de 70.000 plantas/ha) em três épocas de avaliação.

\begin{tabular}{cccccccc}
\hline & & \multicolumn{7}{c}{ Estádio Fenológico } \\
\cline { 3 - 8 } FV $^{1}$ & $\mathrm{GL}^{2}$ & \multicolumn{2}{c}{$3-4\left(54 \mathrm{DAE}^{3}\right)$} & \multicolumn{2}{c}{$5(64 \mathrm{DAE})$} & \multicolumn{2}{c}{8 -9 (107 DAE) } \\
\cline { 3 - 8 } & & $\mathrm{QM}^{4}$ & $\mathrm{~F}$ & $\mathrm{QM}$ & $\mathrm{F}$ & $\mathrm{QM}$ & $\mathrm{F}$ \\
\hline Bloco & 2 & 0,0002 & & 0,0555 & & 0,7607 & \\
Genótipo (G) & 4 & 0,6273 & $4,10^{* *}$ & 1,0013 & $4,96^{* *}$ & 1,1332 & $10,77^{* *}$ \\
Dose (D) & 4 & 7,7043 & $50,36^{* *}$ & 22,6748 & $112,30^{* *}$ & 6,6219 & $62,93^{* *}$ \\
GxD & 16 & 0,3726 & $2,44^{* *}$ & 0,2220 & $1,10^{\mathrm{NS}}$ & 0,1384 & $1,31^{\mathrm{NS}}$ \\
Resíduo & 48 & 0,1530 & & 0,2019 & & 0,1052 & \\
Total & 74 & & & & & & \\
Média & & 3,79 & & 4,41 & & 2,55 & \\
CV $^{5}(\%)$ & & 10,32 & & 10,20 & & 12,72 & \\
\hline
\end{tabular}

$1 \mathrm{FV}$ : fonte da variação 2 GL: graus de liberdade

3 DAE: dias após a emergência

4 QM: quadrado médio

$5 \mathrm{CV}$ : coeficiente de variação 
Tabela 12. Índice área foliar (IAF, $\mathrm{m}^{2} / \mathrm{m}^{2}$ ) (média de 3 repetições) avaliado em três diferentes épocas (experimento 2, data de semeadura: 29 de novembro de 2000, população: 70.000 plantas/ha).

\begin{tabular}{ccccc}
\hline \multirow{2}{*}{ Genótipo } & $\begin{array}{c}\text { Dose } \\
(\mathrm{kg} / \mathrm{ha})\end{array}$ & $3\left(44 \mathrm{DAE}^{2}\right)$ & Estádio Fenológico \\
\cline { 2 - 5 } & 0 & 1,69 & 2,27 & $7(80 \mathrm{DAE})$ \\
\hline P-30F45 & 60 & 2,49 & 3,65 & 1,74 \\
& 120 & 2,94 & 4,61 & 3,77 \\
& 180 & 3,14 & 5,06 & 4,37 \\
& 240 & 3,58 & 5,41 & 4,96 \\
& 0 & 1,37 & 3,61 & 3,12 \\
C-333B & 60 & 2,38 & 4,46 & 3,64 \\
& 120 & 2,75 & 5,02 & 4,46 \\
& 180 & 3,18 & 5,75 & 5,08 \\
& 240 & 3,20 & 6,30 & 5,97 \\
P-30K75 & 0 & 1,71 & 2,23 & 2,07 \\
& 60 & 3,45 & 4,25 & 3,91 \\
& 120 & 3,32 & 4,69 & 4,30 \\
& 180 & 3,72 & 4,98 & 4,52 \\
& 240 & 3,69 & 5,48 & 5,29 \\
CO-9560 & 0 & 1,70 & 2,32 & 2,15 \\
& 60 & 2,92 & 3,75 & 3,40 \\
& 120 & 3,20 & 4,42 & 4,04 \\
& 180 & 3,39 & 4,78 & 4,57 \\
& 240 & 3,58 & 5,49 & 5,22 \\
C-909 & 0 & 1,66 & 2,02 & 1,68 \\
& 60 & 2,65 & 3,06 & 2,73 \\
& 120 & 3,00 & 4,07 & 3,78 \\
& 180 & 3,23 & 4,45 & 3,94 \\
& 240 & 3,57 & 4,88 & 4,41 \\
\hline Dose & & &
\end{tabular}

1 Dose: adubação nitrogenada (kg/ha de nitrogênio).

2 DAE: dias após a emergência. 
Tabela 13. Resumo da análise individual das médias de doses de nitrogênio para índice de área foliar $\left(\mathrm{m}^{2} / \mathrm{m}^{2}\right)$ (experimento 2, população de 70.000 plantas $/ \mathrm{ha}$ ), em três épocas de avaliação, com teste $\mathrm{F}$ para genótipos dentro de doses (média de 3 repetições).

\begin{tabular}{ccccccc}
\hline \multirow{2}{*}{$\begin{array}{c}\text { Dose } \\
(\mathrm{kg} / \mathrm{ha})\end{array}$} & \multicolumn{6}{c}{ Estádio Fenológico } \\
\cline { 2 - 7 } & \multicolumn{2}{c}{$3(44 \mathrm{DAE})$} & \multicolumn{2}{c}{$5-6(65 \mathrm{DAE})$} & \multicolumn{2}{c}{$7(80 \mathrm{DAE})$} \\
\hline 0 & 1,63 & $0,60^{\mathrm{NS}}$ & 2,49 & $9,82^{* *}$ & 2,15 & $7,54^{* *}$ \\
60 & 2,78 & $2,38^{\mathrm{NS}}$ & 3,83 & $1,42^{\mathrm{NS}}$ & 3,29 & $1,31^{\mathrm{NS}}$ \\
120 & 3,04 & $1,63^{\mathrm{NS}}$ & 4,56 & $1,41^{\mathrm{NS}}$ & 4,04 & $2,05^{\mathrm{NS}}$ \\
180 & 3,33 & $1,43^{\mathrm{NS}}$ & 5,00 & $9,24^{* *}$ & 4,50 & $5,30^{*}$ \\
240 & 3,53 & $0,46^{\mathrm{NS}}$ & 5,51 & $3,52^{\mathrm{NS}}$ & 5,17 & $4,71^{*}$ \\
\hline
\end{tabular}

1 Valor $\mathrm{F}$ com graus de liberdade 4 para genótipos (numerador) e 8 para resíduo (denominador).

Tabela 14. Resumo da análise de variância referente ao índice de área foliar $\left(\mathrm{m}^{2} / \mathrm{m}^{2}\right)$ (experimento 2, população de 70.000 plantas/ha) em três épocas de avaliação.

\begin{tabular}{|c|c|c|c|c|c|c|c|}
\hline \multirow{3}{*}{$\mathrm{FV}^{1}$} & \multirow{3}{*}{$\mathrm{GL}^{2}$} & \multicolumn{6}{|c|}{ Estádio Fenológico } \\
\hline & & \multicolumn{2}{|c|}{$3\left(44 \mathrm{DAE}^{3}\right)$} & \multicolumn{2}{|c|}{ 5-6 (65 DAE) } & \multicolumn{2}{|c|}{7 (80 DAE) } \\
\hline & & $\mathrm{QM}^{4}$ & $\mathrm{~F}$ & $\mathrm{QM}$ & $\mathrm{F}$ & $\mathrm{QM}$ & $\mathrm{F}$ \\
\hline Bloco & 2 & 0,1335 & & 0,1729 & & 0,1064 & \\
\hline Genótipo (G) & 4 & 0,7613 & $4,66^{* *}$ & 3,4777 & $12,17 * *$ & 3,0549 & $10,71 * *$ \\
\hline Dose (D) & 4 & 8,3721 & $51,24 * *$ & 20,6986 & $72,45 * *$ & 20,2295 & $70,94 * *$ \\
\hline GxD & 16 & 0,0686 & $0,42^{\mathrm{NS}}$ & 0,1206 & $0,42^{\mathrm{NS}}$ & 0,1531 & $0,54^{\mathrm{NS}}$ \\
\hline Resíduo & 48 & 0,1634 & & 0,2857 & & 0,2852 & \\
\hline Total & 74 & & & & & & \\
\hline Média & & 2,86 & & 4,28 & & 3,83 & \\
\hline $\mathrm{CV}^{5}(\%)$ & & 14,13 & & 12,49 & & 13,94 & \\
\hline
\end{tabular}

$1 \mathrm{FV}$ : fonte da variação

2 GL: graus de liberdade

3 DAE: dias após a emergência

4 QM: quadrado médio

$5 \mathrm{CV}$ : coeficiente de variação 
Tabela 15. Índice área foliar (IAF, $\mathrm{m}^{2} / \mathrm{m}^{2}$ ) (média de 3 repetições) avaliado em cinco diferentes épocas (experimento 3, data de semeadura: 27 de dezembro de 2000, população: 65.625 plantas/ha).

\begin{tabular}{lcccccc}
\hline \multirow{2}{*}{ Genótipo } & $\begin{array}{c}\text { Dose } \\
(\mathrm{kg} / \mathrm{ha})\end{array}$ & \multicolumn{5}{c}{ Estádio Fenológico } \\
\cline { 3 - 7 } & 0 & 1,05 & 2,15 & 1,59 & 1,13 & 0,90 \\
& 60 & 2,63 & 3,30 & 3,04 & 2,52 & 1,96 \\
P-30F45 & 120 & 2,62 & 3,42 & 3,40 & 2,40 & 2,07 \\
& 180 & 3,03 & 3,64 & 3,53 & 2,88 & 2,03 \\
& 240 & 2,78 & 3,62 & 3,86 & 2,87 & 2,27 \\
& 0 & 1,19 & 2,49 & 1,94 & 1,71 & 1,56 \\
& 60 & 2,26 & 3,40 & 3,29 & 2,93 & 2,38 \\
C-333B & 120 & 2,42 & 3,61 & 3,29 & 2,80 & 2,43 \\
& 180 & 2,79 & 3,54 & 3,66 & 3,35 & 2,93 \\
& 240 & 2,54 & 3,80 & 3,72 & 3,14 & 2,72 \\
& 0 & 1,10 & 1,86 & 1,85 & 1,63 & 1,53 \\
& 60 & 2,20 & 3,39 & 3,23 & 2,67 & 2,17 \\
P-30K75 & 120 & 2,35 & 3,49 & 3,57 & 2,70 & 2,30 \\
& 180 & 2,78 & 3,70 & 3,74 & 3,66 & 2,86 \\
& 240 & 2,36 & 3,70 & 3,57 & 2,82 & 2,52 \\
& 0 & 1,30 & 2,17 & 2,10 & 1,79 & 1,66 \\
& 60 & 2,21 & 3,23 & 3,30 & 2,62 & 2,04 \\
CO-9560 & 120 & 2,71 & 3,99 & 3,78 & 3,00 & 2,47 \\
& 180 & 2,84 & 3,95 & 3,93 & 3,52 & 2,72 \\
& 240 & 2,95 & 3,87 & 3,97 & 3,24 & 2,79 \\
& 0 & 1,08 & 2,39 & 1,44 & 1,46 & 1,30 \\
& 60 & 2,10 & 3,21 & 2,96 & 2,34 & 1,96 \\
C-909 & 120 & 2,36 & 3,55 & 3,32 & 2,48 & 2,02 \\
& 180 & 2,67 & 3,44 & 3,22 & 3,09 & 2,19 \\
& 240 & 2,42 & 3,61 & 3,57 & 3,10 & 2,27 \\
\hline
\end{tabular}

1 Dose: adubação nitrogenada ( $\mathrm{kg} / \mathrm{ha}$ de nitrogênio).

2 DAE: dias após a emergência. 
Tabela 16. Resumo da análise individual das médias de doses de nitrogênio para índice de área foliar $\left(\mathrm{m}^{2} / \mathrm{m}^{2}\right)$ (experimento 3, população de 65.625 plantas $/ \mathrm{ha}$ ), em cinco épocas de avaliação, com teste F para genótipos dentro de doses (média de 3 repetições).

\begin{tabular}{ccccccccccc}
\hline \multirow{2}{*}{$\begin{array}{c}\text { Dose } \\
(\mathrm{kg} / \mathrm{ha})\end{array}$} & \multicolumn{10}{c}{ Estádio Fenológico } \\
\cline { 2 - 11 } & Média & $\mathrm{F}^{1}$ & Média & $\mathrm{F}$ & Média & $\mathrm{F}$ & Média & $\mathrm{F}$ & Média & $\mathrm{F}$ \\
\hline 0 & 1,14 & $1,09^{\mathrm{NS}}$ & 2,21 & $3,32^{\mathrm{NS}}$ & 1,78 & $5,16^{*}$ & 1,54 & $7,08^{* *}$ & 1,39 & $5,08^{*}$ \\
60 & 2,28 & $1,65^{\mathrm{NS}}$ & 3,31 & $0,19^{\mathrm{NS}}$ & 3,17 & $1,00^{\mathrm{NS}}$ & 2,61 & $6,17^{*}$ & 2,10 & $0,85^{\mathrm{NS}}$ \\
120 & 2,49 & $2,83^{\mathrm{NS}}$ & 3,61 & $1,54^{\mathrm{NS}}$ & 3,47 & $1,88^{\mathrm{NS}}$ & 2,68 & $4,98^{*}$ & 2,26 & $4,76^{*}$ \\
180 & 2,82 & $2,00^{\mathrm{NS}}$ & 3,65 & $1,4^{\mathrm{NS}}$ & 3,62 & $2,32^{\mathrm{NS}}$ & 3,30 & $7,2^{* *}$ & 2,55 & $12,01^{* *}$ \\
240 & 2,61 & $2,29^{\mathrm{NS}}$ & 3,72 & $0,79^{\mathrm{NS}}$ & 3,74 & $1,52^{\mathrm{NS}}$ & 3,03 & $4,72^{*}$ & 2,51 & $8,18^{* *}$ \\
\hline
\end{tabular}

1 Valor $\mathrm{F}$ com graus de liberdade 4 para genótipos (numerador) e 8 para resíduo (denominador).

Tabela 17. Resumo da análise de variância referente ao índice de área foliar $\left(\mathrm{m}^{2} / \mathrm{m}^{2}\right)$ (experimento 3 , população de 65.625 plantas/ha) em três épocas de avaliação.

\begin{tabular}{|c|c|c|c|c|c|c|c|c|c|c|c|}
\hline \multirow{3}{*}{$\mathrm{FV}^{1}$} & \multirow{3}{*}{$\mathrm{GL}^{2}$} & \multicolumn{10}{|c|}{ Estádio Fenológico } \\
\hline & & \multicolumn{2}{|c|}{$5\left(44 \mathrm{DAE}^{3}\right)$} & \multicolumn{2}{|c|}{5 (58 DAE) } & \multicolumn{2}{|c|}{$6(69 \mathrm{DAE})$} & \multicolumn{2}{|c|}{7 (81 DAE) } & \multicolumn{2}{|c|}{8 (91 DAE) } \\
\hline & & $\overline{\mathrm{QM}^{4}}$ & $\mathrm{~F}$ & $\mathrm{QM}$ & $\mathrm{F}$ & QM & $\mathrm{F}$ & $\overline{\mathrm{QM}}$ & $\mathrm{F}$ & QM & $\mathrm{F}$ \\
\hline Bloco & 2 & 0,0262 & & 0,1076 & & 0,0456 & & 0,0900 & & 0,0498 & \\
\hline Genótipo (G) & 4 & 0,2828 & $6,18^{* *}$ & 0,1468 & $1,91^{\mathrm{NS}}$ & 0,5237 & $4,24 * *$ & 0,5985 & $5,61 * *$ & 0,9282 & $10,45^{* *}$ \\
\hline Dose (D) & 4 & 6,5304 & $142,63 * *$ & 5,9531 & $77,28^{* *}$ & 9,4946 & $76,87 * *$ & 6,7119 & $62,87 * *$ & 3,3031 & $37,19 * *$ \\
\hline GxD & 16 & 0,0479 & $1,05^{\mathrm{NS}}$ & 0,0891 & $1,16^{\mathrm{NS}}$ & 0,0488 & $0,39^{\mathrm{NS}}$ & 0,0789 & $0,74^{\mathrm{NS}}$ & 0,0617 & $0,69^{\mathrm{NS}}$ \\
\hline Resíduo & 48 & 0,0458 & & 0,0770 & & 0,1235 & & 0,1068 & & 0,0888 & \\
\hline Total & 74 & & & & & & & & & & \\
\hline Média & & 2,27 & & 3,30 & & 3,16 & & 2,63 & & 2,16 & \\
\hline $\mathrm{CV}^{5}(\%)$ & & 9,42 & & 8,41 & & 11,14 & & 12,41 & & 13,78 & \\
\hline
\end{tabular}

$1 \mathrm{FV}$ : fonte da variação

2 GL: graus de liberdade

3 DAE: dias após a emergência

4 QM: quadrado médio

$5 \mathrm{CV}$ : coeficiente de variação 
Tabela 18. Índice área foliar (IAF, $\mathrm{m}^{2} / \mathrm{m}^{2}$ ) (média de 3 repetições) avaliado em quatro diferentes épocas (experimento 4, data de semeadura: 22 de fevereiro de 2001, população: 65.625 plantas/ha).

\begin{tabular}{|c|c|c|c|c|c|}
\hline \multirow{2}{*}{ Genótipo } & \multirow{2}{*}{$\begin{array}{c}D_{\text {Dose }} \\
(\mathrm{kg} / \mathrm{ha})\end{array}$} & \multicolumn{4}{|c|}{ Estádio Fenológico } \\
\hline & & $3\left(41 \mathrm{DAE}^{2}\right)$ & 5 (53 DAE) & 6 (67 DAE) & 7 (80 DAE) \\
\hline \multirow{5}{*}{ P-30F45 } & 0 & 1,66 & 2,19 & 1,96 & 1,68 \\
\hline & 60 & 2,68 & 3,53 & 2,99 & 2,65 \\
\hline & 120 & 2,69 & 3,42 & 2,90 & 2,55 \\
\hline & 180 & 3,09 & 3,61 & 3,28 & 3,07 \\
\hline & 240 & 2,95 & 3,88 & 3,61 & 3,01 \\
\hline \multirow{5}{*}{ C-333B } & 0 & 1,75 & 2,77 & 2,82 & 2,83 \\
\hline & 60 & 2,58 & 3,25 & 3,10 & 3,08 \\
\hline & 120 & 2,69 & 3,99 & 3,53 & 3,33 \\
\hline & 180 & 3,16 & 3,76 & 3,22 & 2,95 \\
\hline & 240 & 2,94 & 3,99 & 3,29 & 3,07 \\
\hline \multirow{5}{*}{ P-30K 75} & 0 & 1,37 & 1,98 & 2,20 & 2,14 \\
\hline & 60 & 2,56 & 3,78 & 3,17 & 3,08 \\
\hline & 120 & 2,77 & 3,90 & 3,61 & 3,25 \\
\hline & 180 & 3,31 & 3,77 & 3,54 & 3,40 \\
\hline & 240 & 3,00 & 3,89 & 3,66 & 3,58 \\
\hline \multirow{5}{*}{ CO-9560 } & 0 & 1,70 & 2,12 & 2,15 & 2,38 \\
\hline & 60 & 2,51 & 3,62 & 3,29 & 3,12 \\
\hline & 120 & 2,93 & 3,80 & 3,46 & 3,50 \\
\hline & 180 & 3,03 & 3,88 & 3,66 & 3,51 \\
\hline & 240 & 2,98 & 4,33 & 3,48 & 3,39 \\
\hline \multirow{5}{*}{ C-909 } & 0 & 1,45 & 1,85 & 1,81 & 1,82 \\
\hline & 60 & 2,40 & 3,47 & 2,98 & 2,73 \\
\hline & 120 & 2,74 & 3,68 & 3,31 & 3,10 \\
\hline & 180 & 2,58 & 3,84 & 3,31 & 3,17 \\
\hline & 240 & 2,86 & 4,08 & 3,17 & 2,85 \\
\hline
\end{tabular}

1 Dose: adubação nitrogenada ( $\mathrm{kg} / \mathrm{ha}$ de nitrogênio).

2 DAE: dias após a emergência. 
Tabela 19. Resumo da análise individual das médias de doses de nitrogênio para índice de área foliar $\left(\mathrm{m}^{2} / \mathrm{m}^{2}\right)$ (experimento 4 , população de 65.625 plantas $/ \mathrm{ha}$ ), em quatro épocas de avaliação, com teste $\mathrm{F}$ para genótipos dentro de doses (média de 3 repetições).

\begin{tabular}{|c|c|c|c|c|c|c|c|c|}
\hline \multirow{3}{*}{$\begin{array}{c}\text { Dose } \\
(\mathrm{kg} / \mathrm{ha})\end{array}$} & \multicolumn{8}{|c|}{ Estádio Fenológico } \\
\hline & \multicolumn{2}{|c|}{3 (41 DAE) } & \multicolumn{2}{|c|}{5 (53 DAE) } & \multicolumn{2}{|c|}{6 (67 DAE) } & \multicolumn{2}{|c|}{7 (80 DAE) } \\
\hline & Média & $\mathrm{F}^{1}$ & Média & $\mathrm{F}$ & Média & $\mathrm{F}$ & Média & $\mathrm{F}$ \\
\hline 0 & 1,59 & $6,83^{*}$ & 2,18 & $6,37^{*}$ & 2,19 & $6,52^{*}$ & 2,17 & $10,47^{*}$ \\
\hline 60 & 2,55 & $0,71^{\mathrm{NS}}$ & 3,53 & $5,09 *$ & 3,10 & $0,98^{\mathrm{NS}}$ & 2,93 & $2,48^{\mathrm{NS}}$ \\
\hline 120 & 2,77 & $0,51^{\mathrm{NS}}$ & 3,76 & $1,13^{\mathrm{NS}}$ & 3,36 & $4,28^{*}$ & 3,15 & $5,05 *$ \\
\hline 180 & 3,03 & $4,87^{*}$ & 3,77 & $0,87^{\mathrm{NS}}$ & 3,40 & $1,27^{\mathrm{NS}}$ & 3,22 & $1,88^{\mathrm{NS}}$ \\
\hline 240 & 2,94 & $0,47^{\mathrm{NS}}$ & 4,03 & $2,24^{\mathrm{NS}}$ & 3,44 & $1,47^{\mathrm{NS}}$ & 3,18 & $3,20^{\mathrm{NS}}$ \\
\hline
\end{tabular}

Tabela 20. Resumo da análise de variância referente ao índice de área foliar $\left(\mathrm{m}^{2} / \mathrm{m}^{2}\right)$ (experimento 4, população de 65.625 plantas/ha) em três épocas de avaliação.

\begin{tabular}{|c|c|c|c|c|c|c|c|c|c|}
\hline \multirow{3}{*}{$\mathrm{FV}^{1}$} & \multirow{3}{*}{$\mathrm{GL}^{2}$} & \multicolumn{8}{|c|}{ Estádio Fenológico } \\
\hline & & \multicolumn{2}{|c|}{$3\left(41 \mathrm{DAE}^{3}\right)$} & \multicolumn{2}{|c|}{5 (53 DAE) } & \multicolumn{2}{|c|}{6 (67 DAE) } & \multicolumn{2}{|c|}{7 (80 DAE) } \\
\hline & & $\mathrm{QM}^{4}$ & $\mathrm{~F}$ & QM & $\mathrm{F}$ & QM & $\mathrm{F}$ & QM & $\mathrm{F}$ \\
\hline Blocos & 2 & 0,1569 & & 0,1487 & & 1,5727 & & 1,6321 & \\
\hline Genótipo (G) & 4 & 0,1336 & $1,46^{\mathrm{NS}}$ & 0,1521 & $2,35^{\mathrm{NS}}$ & 0,3565 & $4,57 * *$ & 0,9613 & $13,19^{* *}$ \\
\hline Dose (D) & 4 & 5,0991 & $55,55 * *$ & 8,0763 & $124,85^{* *}$ & 4,1387 & $53,09 * *$ & 2,8862 & $39,60 * *$ \\
\hline GxD & 16 & 0,0601 & $0,65^{\mathrm{NS}}$ & 0,1550 & $2,40^{*}$ & 0,1530 & $1,96^{*}$ & 0,1599 & $2,19^{*}$ \\
\hline Resíduo & 48 & 0,0918 & & 0,0647 & & 0,0780 & & 0,0729 & \\
\hline Total & 74 & & & & & & & & \\
\hline Média & & 2,58 & & 3,45 & & 3,10 & & 2,93 & \\
\hline$C V^{5}(\%)$ & & 11,76 & & 7,36 & & 9,01 & & 9,21 & \\
\hline
\end{tabular}

$1 \mathrm{FV}$ : fonte da variação

2 GL: graus de liberdade

3 DAE: dias após a emergência

4 QM: quadrado médio

$5 \mathrm{CV}$ : coeficiente de variação 


\subsubsection{Componentes de produção}

Nas Tabelas seguintes (Tabela 21, Tabela 22, Tabela 23, Tabela 24) estão apresentados os dados relativos aos seguintes componentes de produção, dos quatro experimentos avaliados: altura da planta (AP), altura da espiga (AE), comprimento do primeiro internódio (Ci1), diâmetro do colmo (Dc) no primeiro internódio, prolificidade (Pr), comprimento da espiga (CE), diâmetro do sabugo (Ds), número de fileiras (NF) por espiga, número de grãos por fileira (NGF) por espiga, estande nas duas linhas centrais da parcela e diâmetro da espiga (DE).

O que pode ser observado nos dados apresentados é que, praticamente todos os componentes de produção, em todos os experimentos e genótipos estudados, ocorreu resposta em relação à adubação nitrogenada. Isso mostra o importante e fundamental papel que o nutriente desempenha no incremento biológico da cultura de milho. 
Tabela 21. Resumo dos diferentes componentes de produção avaliados no experimento 1 para os cinco genótipos utilizados e respectivos efeitos da análise de regressão em função de doses de nitrogênio.

\begin{tabular}{|c|c|c|c|c|c|c|c|c|c|c|c|c|c|c|c|c|c|c|c|c|c|c|c|}
\hline Genótipo & Dose & $\mathrm{AP}$ & & $\mathrm{AE}$ & & Ci1 & & Dc & & $\operatorname{Pr}$ & & $\mathrm{CE}$ & & Ds & & $\mathrm{NF}$ & & NGF & & Estande & & $\mathrm{DE}$ & \\
\hline \multirow{5}{*}{ P-30F45 } & 0 & 156,5 & & 72,8 & & 77,0 & & 17,1 & & 1,00 & & 11,2 & & 2,2 & & 13,1 & & 20,5 & & 42 & & 3,9 & \\
\hline & 60 & 207,8 & & 115,0 & & 118,5 & & 19,8 & & 0,95 & & 13,8 & & 2,4 & & 12,9 & & 25,7 & & 42 & & 4,2 & \\
\hline & 120 & 221,0 & $* *$ & 122,7 & $* *$ & 115,7 & $* *$ & 22,6 & $* *$ & 0,94 & ns & 16,5 & $*$ & 2,6 & $*$ & 13,5 & ns & 31,3 & $* *$ & 43 & ns & 4,5 & $* *$ \\
\hline & 180 & 226,7 & & 128,2 & & 124,6 & & 20,5 & & 0,98 & & 17,1 & & 2,6 & & 13,7 & & 31,9 & & 43 & & 4,6 & \\
\hline & 240 & 221,2 & & 125,3 & & 128,1 & & 23,2 & & 0,98 & & 18,9 & & 2,7 & & 13,2 & & 34,7 & & 43 & & 4,8 & \\
\hline \multirow{5}{*}{ C-333B } & 0 & 150,2 & & 62,7 & & 64,9 & & 17,0 & & 0,63 & & 12,1 & & 2,1 & & 13,2 & & 24,7 & & 42 & & 3,8 & \\
\hline & 60 & 196,2 & & 100,2 & & 96,9 & & 20,1 & & 0,80 & & 13,0 & & 2,2 & & 14,0 & & 28,3 & & 43 & & 4,3 & \\
\hline & 120 & 206,5 & $* *$ & 109,5 & $* *$ & 97,9 & $* *$ & 23,3 & $*$ & 0,91 & ns & 15,1 & ns & 2,4 & $*$ & 14,3 & ns & 33,8 & $*$ & 42 & ns & 4,6 & $* *$ \\
\hline & 180 & 218,0 & & 115,7 & & 104,0 & & 24,4 & & 1,01 & & 17,1 & & 2,6 & & 14,9 & & 37,2 & & 41 & & 4,9 & \\
\hline & 240 & 215,8 & & 115,2 & & 111,0 & & 24,4 & & 1,08 & & 18,0 & & 2,7 & & 14,3 & & 38,5 & & 40 & & 5,0 & \\
\hline \multirow{4}{*}{ P-30K75 } & 0 & 133,3 & & 59,2 & & 66,3 & & 16,4 & & 0,95 & & 10,7 & & 2,5 & & 14,3 & & 21,8 & & 42 & & 4,2 & \\
\hline & 60 & 177,2 & & 91,2 & & 101,3 & & 19,9 & & 0,91 & & 14,2 & & 2,8 & & 14,8 & & 29,5 & & 42 & & 4,5 & \\
\hline & 120 & 195,6 & $* *$ & 104,0 & $* *$ & 103,1 & $* *$ & 21,5 & $*$ & 0,98 & ns & 16,9 & $* *$ & 2,8 & $*$ & 14,9 & ns & 35,9 & $* *$ & 42 & ns & 4,8 & $*$ \\
\hline & 180 & 199,0 & & 109,0 & & 121,6 & & 22,0 & & 0,98 & & 17,5 & & 2,8 & & 14,7 & & 37,1 & & 42 & & 4,7 & \\
\hline \multirow{5}{*}{ CO-9560 } & 0 & 144,2 & & 63,5 & & 67,1 & & 15,5 & & 0,95 & & 11,0 & & 2,3 & & 14,7 & & 21,6 & & 42 & & 4,3 & \\
\hline & 60 & 193,3 & & 101,8 & & 101,7 & & 19,8 & & 0,95 & & 13,2 & & 2,6 & & 15,2 & & 27,5 & & 42 & & 4,6 & \\
\hline & 120 & 197,5 & $* *$ & 105,2 & $* *$ & 108,3 & $* *$ & 22,9 & $* *$ & 0,99 & ns & 15,3 & $*$ & 2,6 & $*$ & 14,4 & ns & 34,1 & $*$ & 44 & $\mathrm{~ns}$ & 4,8 & ns \\
\hline & 180 & 207,0 & & 110,0 & & 112,6 & & 23,6 & & 0,95 & & 16,2 & & 2,8 & & 15,5 & & 35,7 & & 41 & & 5,0 & \\
\hline & 240 & 200,5 & & 135,2 & & 101,3 & & 23,4 & & 0,98 & & 16,6 & & 2,8 & & 15,1 & & 35,8 & & 41 & & 5,1 & \\
\hline \multirow{5}{*}{ C-909 } & 0 & 152,0 & & 62,8 & & 75,5 & & 15,4 & & 0,89 & & 11,7 & & 2,5 & & 14,7 & & 23,4 & & 43 & & 4,0 & \\
\hline & 60 & 209,3 & & 97,7 & & 103,3 & & 20,6 & & 0,92 & & 15,1 & & 2,6 & & 14,5 & & 30,9 & & 42 & & 4,4 & \\
\hline & 120 & 224,3 & $* *$ & 105,2 & $* *$ & 108,8 & $* *$ & 22,4 & $* *$ & 1,01 & ns & 16,7 & $* *$ & 2,8 & $*$ & 14,8 & ns & 33,4 & $* *$ & 42 & ns & 4,6 & $* *$ \\
\hline & 180 & 220,5 & & 100,3 & & 114,1 & & 24,3 & & 0,98 & & 18,8 & & 2,9 & & 14,3 & & 37,9 & & 42 & & 4,8 & \\
\hline & 240 & 222,7 & & 99,2 & & 111,7 & & 24,6 & & 0,98 & & 19,3 & & 2,9 & & 14,8 & & 38,9 & & 42 & & 4,8 & \\
\hline
\end{tabular}

ns: efeito de dose não significativo; *: efeito linear de dose; **: efeito quadrático de dose, todos a nível de $5 \%$ de probabilidade. 
Tabela 22. Resumo dos diferentes componentes de produção avaliados no experimento 2 para os cinco genótipos utilizados e respectivos efeitos da análise de regressão em função de doses de nitrogênio.

\begin{tabular}{|c|c|c|c|c|c|c|c|c|c|c|c|c|c|c|c|c|c|c|c|c|c|c|c|}
\hline Genótipo & Dose & AP & & $\mathrm{AE}$ & & Ci1 & & Dc & & $\mathrm{Pr}$ & & $\mathrm{CE}$ & & Ds & & $\mathrm{NF}$ & & $\mathrm{NGF}$ & & Estande & & $\mathrm{DE}$ & \\
\hline \multirow{5}{*}{ P-30F45 } & 0 & 169,7 & & 85,8 & & 76,7 & & 17,8 & & 1,0 & & 9,8 & & 2,3 & & 13,1 & & 19,1 & & 42,7 & & 3,4 & \\
\hline & 60 & 203,3 & & 105,3 & & 99,6 & & 19,6 & & 1,0 & & 13,2 & & 2,4 & & 12,8 & & 19,1 & & 43,0 & & 3,9 & \\
\hline & 120 & 228,0 & $* *$ & 125,7 & $* *$ & 116,8 & $* *$ & 21,4 & $* *$ & 1,0 & ns & 14,7 & $*$ & 2,4 & ns & 13,5 & ns & 27,1 & $*$ & 43,7 & ns & 4,0 & $*$ \\
\hline & 180 & 224,7 & & 124,3 & & 126,5 & & 21,6 & & 1,0 & & 16,2 & & 2,6 & & 13,3 & & 31,5 & & 43,3 & & 4,4 & \\
\hline & 240 & 231,7 & & 129,7 & & 139,4 & & 21,7 & & 1,0 & & 18,5 & & 2,7 & & 12,9 & & 35,6 & & 43,3 & & 4,5 & \\
\hline \multirow{5}{*}{ C-333B } & 0 & 179,7 & & 88,2 & & 67,7 & & 18,8 & & 0,7 & & 12,1 & & 2,2 & & 13,7 & & 23,9 & & 42,3 & & 3,8 & \\
\hline & 60 & 200,0 & & 110,0 & & 87,2 & & 21,1 & & 0,9 & & 12,9 & & 2,4 & & 13,9 & & 28,5 & & 44,0 & & 4,0 & \\
\hline & 120 & 219,7 & $*$ & 123,3 & $*$ & 97,6 & $*$ & 23,2 & $* *$ & 1,0 & $*$ & 14,6 & ns & 2,4 & $*$ & 14,4 & $* *$ & 30,7 & $*$ & 40,7 & ns & 4,4 & $*$ \\
\hline & 180 & 218,0 & & 124,0 & & 106,4 & & 22,9 & & 1,0 & & 15,5 & & 2,5 & & 14,7 & & 32,0 & & 42,3 & & 4,5 & \\
\hline & 240 & 239,3 & & 140,3 & & 125,3 & & 24,2 & & 1,0 & & 17,1 & & 2,6 & & 13,7 & & 34,2 & & 43,0 & & 4,6 & \\
\hline \multirow{4}{*}{ P-30K 75} & 0 & 142,7 & & 65,0 & & 67,8 & & 16,4 & & 1,0 & & 10,1 & & 2,3 & & 14,1 & & 20,9 & & 42,3 & & 4,0 & \\
\hline & 60 & 176,7 & & 89,7 & & 87,9 & & 20,9 & & 1,0 & & 12,1 & & 2,5 & & 14,3 & & 27,7 & & 42,7 & & 4,2 & \\
\hline & 120 & 192,7 & $* *$ & 102,2 & $* *$ & 104,8 & $* *$ & 21,1 & $* *$ & 1,0 & ns & 15,6 & $* *$ & 2,7 & $*$ & 14,1 & ns & 31,2 & $* *$ & 43,3 & ns & 4,5 & $*$ \\
\hline & 180 & 192,0 & & 110,3 & & 108,4 & & 20,5 & & 1,0 & & 16,9 & & 2,7 & & 14,5 & & 33,9 & & 43,0 & & 4,5 & \\
\hline \multirow{5}{*}{ CO-9560 } & 0 & 160,3 & & 75,5 & & 70,8 & & 16,3 & & 1,0 & & 10,1 & & 2,3 & & 14,7 & & 22,6 & & 41,0 & & 4,1 & \\
\hline & 60 & 184,0 & & 92,8 & & 91,1 & & 19,7 & & 1,0 & & 13,6 & & 2,4 & & 14,7 & & 29,1 & & 43,3 & & 4,5 & \\
\hline & 120 & 202,3 & $* *$ & 108,8 & $* *$ & 105,7 & $* *$ & 20,5 & $* *$ & 1,0 & ns & 13,7 & $*$ & 2,5 & $*$ & 15,2 & ns & 31,5 & $* *$ & 43,3 & ns & 4,5 & $*$ \\
\hline & 180 & 205,7 & & 113,7 & & 114,6 & & 20,9 & & 1,0 & & 16,4 & & 2,6 & & 14,7 & & 33,1 & & 41,7 & & 4,8 & \\
\hline & 240 & 205,7 & & 113,3 & & 110,3 & & 21,7 & & 1,0 & & 16,9 & & 2,6 & & 14,8 & & 34,5 & & 42,3 & & 4,9 & \\
\hline \multirow{5}{*}{ C-909 } & 0 & 167,3 & & 74,8 & & 73,0 & & 15,7 & & 1,0 & & 11,2 & & 2,3 & & 13,7 & & 22,7 & & 42,3 & & 3,9 & \\
\hline & 60 & 184,3 & & 85,7 & & 88,9 & & 19,1 & & 1,0 & & 13,5 & & 2,5 & & 14,5 & & 25,9 & & 43,3 & & 4,1 & \\
\hline & 120 & 210,0 & $* *$ & 102,3 & $*$ & 107,4 & $*$ & 21,4 & $* *$ & 1,0 & ns & 16,0 & $*$ & 2,6 & $*$ & 14,5 & $*$ & 34,3 & $* *$ & 42,0 & ns & 4,3 & $* *$ \\
\hline & 180 & 224,0 & & 117,0 & & 113,8 & & 21,9 & & 1,0 & & 17,9 & & 2,7 & & 14,7 & & 35,2 & & 43,0 & & 4,5 & \\
\hline & 240 & 228,7 & & 119,3 & & 126,4 & & 23,3 & & 1,0 & & 19,1 & & 2,8 & & 14,5 & & 34,9 & & 43,7 & & 4,5 & \\
\hline
\end{tabular}

ns: efeito de dose não significativo; *: efeito linear de dose; **: efeito quadrático de dose, todos a nível de $5 \%$ de probabilidade. 
Tabela 23. Resumo dos diferentes componentes de produção avaliados no experimento 3 para os cinco genótipos utilizados e respectivos efeitos da análise de regressão em função de doses de nitrogênio.

\begin{tabular}{|c|c|c|c|c|c|c|c|c|c|c|c|c|c|c|c|c|c|c|c|c|c|c|c|}
\hline Genótipo & Dose & AP & & $\mathrm{AE}$ & & Cil & & Dc & & $\mathrm{Pr}$ & & $\mathrm{CE}$ & & $\mathrm{DE}$ & & Ds & & NF & & NGF & & Estande & \\
\hline \multirow{5}{*}{ P-30F45 } & 0 & 123,3 & & 56,3 & & 63,0 & & 15,1 & & 0,8 & & 10,4 & & 3,7 & & 2,1 & & 12,9 & & 18,0 & & 42,3 & \\
\hline & 60 & 224,2 & & 116,7 & & 108,9 & & 20,2 & & 1,0 & & 17,3 & & 4,3 & & 2,5 & & 13,9 & & 33,7 & & 41,0 & \\
\hline & 120 & 229,0 & $* *$ & 120,5 & $* *$ & 125,8 & $* *$ & 20,9 & $* *$ & 1,0 & * & 17,2 & $* *$ & 4,3 & $* *$ & 2,5 & $*$ & 13,9 & $* *$ & 32,5 & $* *$ & 42,0 & ns \\
\hline & 180 & 236,8 & & 134,5 & & 131,3 & & 22,7 & & 1,0 & & 17,3 & & 4,4 & & 2,6 & & 13,3 & & 35,3 & & 41,3 & \\
\hline & 240 & 241,7 & & 129,7 & & 144,1 & & 22,8 & & 1,0 & & 18,1 & & 4,4 & & 2,6 & & 13,5 & & 36,4 & & 41,3 & \\
\hline \multirow{5}{*}{ C-333B } & 0 & 139,0 & & 66,7 & & 62,9 & & 15,6 & & 0,9 & & 13,7 & & 4,3 & & 2,3 & & 12,3 & & 30,3 & & 41,3 & \\
\hline & 60 & 202,3 & & 103,2 & & 92,7 & & 20,2 & & 0,9 & & 16,4 & & 4,6 & & 2,5 & & 13,2 & & 34,2 & & 39,7 & \\
\hline & 120 & 213,3 & ** & 111,0 & $* *$ & 102,2 & $* *$ & 22,4 & ** & 1,0 & * & 17,0 & ** & 4,7 & ** & 2,6 & $*$ & 14,3 & ** & 36,0 & * & 40,7 & ns \\
\hline & 180 & 224,0 & & 118,0 & & 113,4 & & 23,8 & & 1,1 & & 16,5 & & 4,7 & & 2,6 & & 14,8 & & 36,0 & & 39,3 & \\
\hline & 240 & 219,5 & & 115,0 & & 110,2 & & 24,1 & & 1,1 & & 17,1 & & 4,8 & & 2,6 & & 14,3 & & 35,9 & & 39,7 & \\
\hline \multirow{5}{*}{ P-30K 75} & 0 & 118,0 & & 56,8 & & 62,9 & & 14,6 & & 0,9 & & 13,5 & & 4,4 & & 2,5 & & 13,6 & & 28,0 & & 41,0 & \\
\hline & 60 & 176,7 & & 87,7 & & 94,8 & & 19,7 & & 1,0 & & 15,0 & & 4,6 & & 2,6 & & 14,5 & & 32,3 & & 40,0 & \\
\hline & 120 & 184,0 & ** & 96,2 & ** & 108,3 & ** & 20,6 & ** & 1,0 & * & 16,3 & * & 4,6 & * & 2,6 & * & 15,1 & ** & 32,6 & ns & 41,7 & ns \\
\hline & 180 & 190,3 & & 99,7 & & 114,7 & & 21,7 & & 1,0 & & 16,1 & & 4,8 & & 2,7 & & 14,1 & & 35,1 & & 40,7 & \\
\hline & 240 & 193,3 & & 100,0 & & 123,3 & & 21,6 & & 1,0 & & 17,2 & & 4,8 & & 2,7 & & 14,4 & & 36,7 & & 40,0 & \\
\hline \multirow{5}{*}{ CO-9560 } & 0 & 130,3 & & 59,0 & & 68,1 & & 14,0 & & 1,0 & & 13,1 & & 4,6 & & 2,4 & & 14,7 & & 27,5 & & 41,7 & \\
\hline & 60 & 183,5 & & 91,7 & & 92,6 & & 18,6 & & 1,0 & & 14,9 & & 4,8 & & 2,5 & & 14,8 & & 31,1 & & 41,0 & \\
\hline & 120 & 199,0 & $* *$ & 101,3 & ** & 111,8 & $* *$ & 21,9 & $* *$ & 1,0 & ns & 15,1 & * & 4,8 & * & 2,6 & * & 15,1 & $\mathrm{~ns}$ & 32,0 & * & 41,7 & ns \\
\hline & 180 & 209,0 & & 107,2 & & 115,3 & & 22,1 & & 1,0 & & 16,4 & & 4,9 & & 2,6 & & 15,5 & & 35,2 & & 41,3 & \\
\hline & 240 & 206,3 & & 107,7 & & 106,2 & & 21,8 & & 1,0 & & 16,7 & & 4,9 & & 2,7 & & 15,1 & & 35,1 & & 42,3 & \\
\hline \multirow{5}{*}{ C-909 } & 0 & 116,5 & & 53,8 & & 58,9 & & 12,7 & & 0,9 & & 12,9 & & 4,1 & & 2,4 & & 13,5 & & 24,7 & & 40,3 & \\
\hline & 60 & 200,3 & & 86,8 & & 91,1 & & 18,2 & & 1,0 & & 16,6 & & 4,4 & & 2,7 & & 14,4 & & 33,7 & & 42,3 & \\
\hline & 120 & 211,5 & $* *$ & 94,8 & $* *$ & 104,0 & $* *$ & 20,0 & $* *$ & 1,0 & * & 17,8 & $* *$ & 4,5 & $* *$ & 2,6 & * & 14,4 & $* *$ & 35,9 & $* *$ & 41,0 & ns \\
\hline & 180 & 213,3 & & 95,5 & & 108,6 & & 22,8 & & 1,0 & & 18,0 & & 4,5 & & 2,7 & & 14,7 & & 34,9 & & 41,0 & \\
\hline & 240 & 218,7 & & 98,5 & & 111,2 & & 21,2 & & 1,0 & & 17,7 & & 4,4 & & 2,8 & & 14,0 & & 35,9 & & 40,7 & \\
\hline
\end{tabular}

ns: efeito de dose não significativo; *: efeito linear de dose; **: efeito quadrático de dose, todos a nível de $5 \%$ de probabilidade. 
Tabela 24. Resumo dos diferentes componentes de produção avaliados no experimento 4 para os cinco genótipos utilizados e respectivos efeitos da análise de regressão em função de doses de nitrogênio.

\begin{tabular}{|c|c|c|c|c|c|c|c|c|c|c|c|c|c|c|c|c|c|c|c|c|c|c|c|}
\hline Genótipo & Dose & AP & & $\mathrm{AE}$ & & Ci1 & & Dc & & $\operatorname{Pr}$ & & $\mathrm{CE}$ & & Ds & & NF & & NGF & & Estande & & DE & \\
\hline \multirow{5}{*}{ P-30F45 } & 0 & 178,7 & & 89,3 & & 90,6 & & 17,7 & & 1,1 & & 14,3 & & 2,4 & & 13,6 & & 27,5 & & 41,7 & & 3,9 & \\
\hline & 60 & 222,0 & & 106,3 & & 118,9 & & 20,4 & & 1,1 & & 17,0 & & 2,5 & & 14,0 & & 35,7 & & 41,3 & & 4,0 & \\
\hline & 120 & 225,8 & $* *$ & 111,0 & $* *$ & 126,5 & $* *$ & 20,8 & $* *$ & 1,1 & ns & 16,4 & $*$ & 2,6 & $*$ & 13,2 & ns & 34,0 & $* *$ & 41,7 & ns & 4,1 & $* *$ \\
\hline & 180 & 227,2 & & 117,7 & & 132,4 & & 22,2 & & 1,1 & & 17,2 & & 2,6 & & 13,1 & & 35,7 & & 41,0 & & 4,2 & \\
\hline & 240 & 231,0 & & 116,7 & & 136,4 & & 21,7 & & 1,2 & & 18,0 & & 2,7 & & 13,7 & & 35,9 & & 42,7 & & 4,2 & \\
\hline \multirow{5}{*}{ C-333B } & 0 & 170,5 & & 78,0 & & 80,2 & & 18,1 & & 1,0 & & 14,5 & & 2,5 & & 13,6 & & 28,0 & & 41,7 & & 4,4 & \\
\hline & 60 & 199,3 & & 90,8 & & 105,4 & & 20,9 & & 1,0 & & 15,0 & & 2,6 & & 13,7 & & 29,7 & & 42,0 & & 4,7 & \\
\hline & 120 & 205,2 & $* *$ & 94,2 & $* *$ & 111,6 & $* *$ & 21,0 & $*$ & 1,0 & ns & 15,2 & ns & 2,7 & $*$ & 14,4 & ns & 32,1 & $*$ & 41,3 & ns & 4,7 & $* *$ \\
\hline & 180 & 210,7 & & 94,3 & & 109,5 & & 20,6 & & 1,0 & & 15,6 & & 2,7 & & 14,4 & & 32,8 & & 42,0 & & 4,7 & \\
\hline & 240 & 199,0 & & 92,7 & & 117,0 & & 22,5 & & 1,0 & & 15,6 & & 2,7 & & 14,1 & & 33,9 & & 42,0 & & 4,7 & \\
\hline \multirow{4}{*}{ P-30K75 } & 0 & 145,0 & & 65,2 & & 67,2 & & 16,8 & & 1,1 & & 12,4 & & 2,5 & & 13,6 & & 25,4 & & 41,7 & & 4,3 & \\
\hline & 60 & 185,5 & & 87,2 & & 105,5 & & 18,8 & & 1,1 & & 15,1 & & 2,6 & & 14,7 & & 32,1 & & 41,7 & & 4,5 & \\
\hline & 120 & 195,8 & $* *$ & 94,5 & $* *$ & 121,8 & $* *$ & 19,5 & $*$ & 1,1 & ns & 16,0 & $* *$ & 2,7 & $*$ & 13,9 & ns & 36,1 & $* *$ & 42,3 & ns & 4,6 & $*$ \\
\hline & 180 & 190,0 & & 92,5 & & 117,9 & & 19,9 & & 1,2 & & 15,7 & & 2,6 & & 14,4 & & 35,0 & & 41,7 & & 4,6 & \\
\hline \multirow{5}{*}{ CO-9560 } & 0 & 154,7 & & 67,0 & & 72,2 & & 15,5 & & 1,0 & & 11,2 & & 2,5 & & 14,8 & & 22,3 & & 42,0 & & 4,6 & \\
\hline & 60 & 194,5 & & 92,5 & & 112,6 & & 20,3 & & 1,0 & & 12,9 & & 2,7 & & 14,7 & & 26,7 & & 41,3 & & 4,6 & \\
\hline & 120 & 200,0 & $* *$ & 94,8 & $* *$ & 111,6 & $* *$ & 19,6 & $* *$ & 1,0 & ns & 14,1 & $*$ & 2,7 & $*$ & 15,3 & ns & 30,6 & $*$ & 42,3 & ns & 4,7 & ns \\
\hline & 180 & 195,2 & & 93,7 & & 119,3 & & 21,2 & & 1,0 & & 14,8 & & 2,8 & & 14,9 & & 31,5 & & 41,3 & & 4,8 & \\
\hline & 240 & 200,5 & & 94,5 & & 122,2 & & 21,4 & & 1,0 & & 15,2 & & 2,8 & & 15,6 & & 34,1 & & 42,3 & & 4,8 & \\
\hline \multirow{5}{*}{ C-909 } & 0 & 168,2 & & 74,0 & & 77,5 & & 15,8 & & 1,2 & & 12,1 & & 2,3 & & 14,1 & & 24,4 & & 41,3 & & 3,9 & \\
\hline & 60 & 208,2 & & 93,0 & & 110,5 & & 20,8 & & 1,2 & & 15,8 & & 2,5 & & 14,3 & & 31,2 & & 42,0 & & 4,2 & \\
\hline & 120 & 218,2 & $* *$ & 101,3 & $* *$ & 112,6 & $* *$ & 20,7 & $* *$ & 1,2 & ns & 16,1 & $* *$ & 2,6 & $*$ & 14,7 & ns & 35,3 & $* *$ & 42,7 & ns & 4,3 & $* *$ \\
\hline & 180 & 226,2 & & 101,7 & & 119,5 & & 21,1 & & 1,2 & & 16,6 & & 2,6 & & 14,4 & & 34,1 & & 41,0 & & 4,3 & \\
\hline & 240 & 222,0 & & 100,5 & & 126,9 & & 21,5 & & 1,2 & & 16,6 & & 2,6 & & 14,5 & & 36,0 & & 42,3 & & 4,3 & \\
\hline
\end{tabular}

ns: efeito de dose não significativo; *: efeito linear de dose; **: efeito quadrático de dose, todos a nível de $5 \%$ de probabilidade. 


\subsubsection{Rendimento de grãos de milho}

As Figuras (Figura 3, Figura 4, Figura 5 e Figura 6) a seguir ilustram a variação do rendimento de grãos $(\mathrm{kg} / \mathrm{ha})$ em função de doses crescentes de nitrogênio nos quatro experimentos (dois locais em quatro épocas de semeadura).

A disponibilidade do nitrogênio no solo para a cultura de milho possui fundamental relação para o aumento do rendimento de grãos. A aplicação do nutriente pode proporcionar aumentos significativos quando da utilização de genótipos com alto potencial de resposta, associada ou não a fatores (bióticos e abióticos) que favoreçam o bom crescimento e desenvolvimento das plantas.

Essa situação pode ser observada nos experimentos 1 e 2 (local 1), onde praticamente todas as condições foram favoráveis para o bom desempenho dos genótipos utilizados. Houve resposta da aplicação crescente de doses do nutriente nas referidas épocas de semeadura, sendo que os rendimentos para os genótipos 1 (P-30F45), 2 (C-333B) e 5 (C-909) foram linearmente crescentes e, para os genótipos 3 (P-30K75) e 4 (CO-9560), o efeito de doses está representado pelas equações quadráticas (1 FV: Fonte de variação.

2 GL: Graus de liberdade.

3 Prob: Probabilidade a nível de 5\%.

Tabela 32 e Tabela 34, ANEXO B). Foi verificada ainda, diferença significativa entre o genótipo 1 e os demais estudados no experimento 1 (Tabela 33, ANEXO B; Figura 3), sendo que no experimento 2, não houve diferença significativa entre os genótipos (Tabela 35, ANEXO B; Figura 4).

\section{$\mathrm{Na}$ ANEXO B}

Tabela 31, ANEXO B, diferenças significativas são verificadas para os efeitos de doses de nitrogênio e para os efeitos de genótipos (experimentos 3 e 4). Na análise de regressão para o experimento 3 (Tabela 36, ANEXO B), verifica-se efeito quadrático em função de doses de nitrogênio para todos os genótipos, com exceção do genótipo 2. No experimento 4 (Tabela 38, ANEXO B), o mesmo efeito se repetiu, exceto para o genótipo 4.

Ainda no experimento 3, diferenças significativas foram verificadas entre o genótipo 1 e os demais genótipos, para o parâmetro rendimento. Também foram detectadas diferenças entre os genótipos 2 e 5 e entre os genótipos 4 e 5 para o mesmo parâmetro (Tabela 37, ANEXO B).

No experimento 4, pode-se verificar diferenças significativas entre o genótipo 1 e os genótipos 2 e 4; entre os genótipos 2, 3 e 4 e o genótipo 5 (Tabela 39, ANEXO B), 
indicando assim que o rendimento dos genótipos 1 e 5 foi afetado em pelo uma das combinações genótipos com doses de nitrogênio, nos dois experimentos citados (3 e 4).

Sendo assim, ficou verificado que nos experimentos 3 e 4 (local 2), a aplicação doses de nitrogênio não obedeceu a mesma curva de resposta observada nos dois primeiros experimentos. Algumas situações de estresse podem ter contribuído para o baixo desempenho dos genótipos. Um primeiro fator poderia estar relacionado ao tipo de solo. Um segundo fator, de crucial efeito, estaria relacionado com a época de semeadura a que foram submetidos os dois últimos ensaios para o referido local. Períodos de altas temperaturas (principalmente noturnas) foram observados durante os meses de janeiro e fevereiro, coincidindo com os períodos da fase vegetativa do experimento 3 , o que repercutiu diretamente no encurtamento do período para o florescimento dos genótipos (Tabela 8), especialmente àqueles considerados superprecoces para atingir o florescimento. Um terceiro fator adicional estaria relacionado com a incidência e a severidade causada por P. maydis.

Cumpre salientar que para os experimentos 3 e 4 (semeadura de dezembro e fevereiro), decréscimos no rendimento foram verificados nas doses de 180 e $240 \mathrm{~kg} / \mathrm{ha}$ de nitrogênio, devido ao surgimento de podridões da espiga em genótipos susceptíveis e de ciclo curto (superprecoces), não recomendados para o período. 


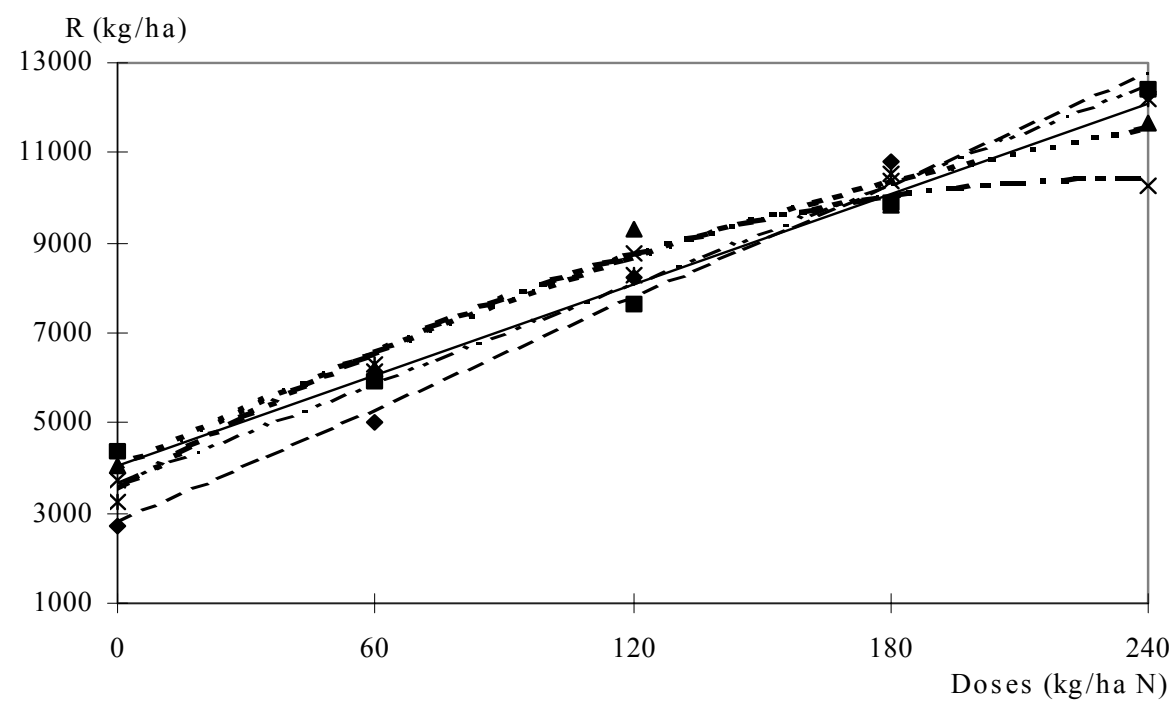

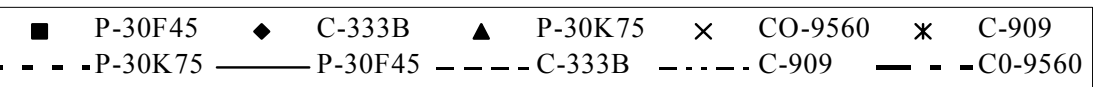

Figura 3 - Rendimento de grãos de milho (R, kg/ha) em função de doses crescentes de nitrogênio. Experimento 1. Data de semeadura: 11 de setembro de 2000.

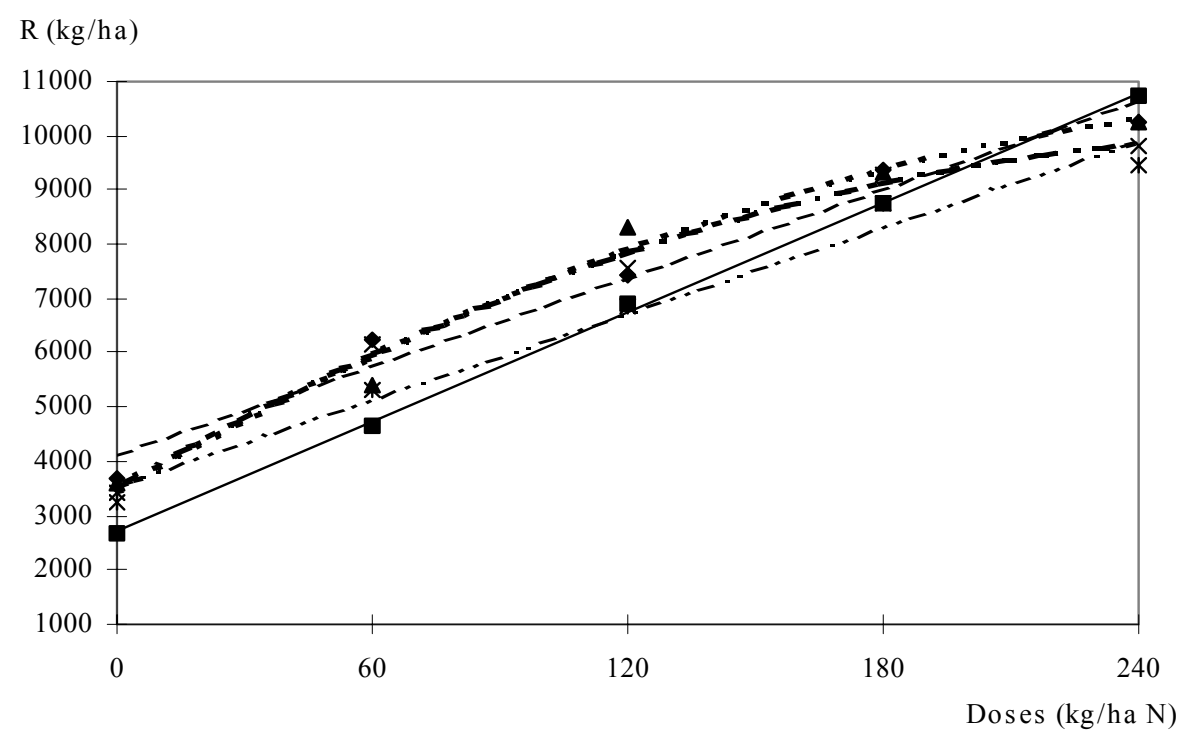

\begin{tabular}{|c|c|c|c|c|c|}
\hline $\begin{array}{rr}\text { - } & \text { P-30F } 45 \\
- & -\end{array}$ & $\bullet$ & $\begin{array}{r}\text { C-333B } \\
-\mathrm{P}-30 \mathrm{~F} 45\end{array}$ & $\begin{array}{c}\Delta \quad \mathrm{P}-30 \mathrm{~K} 75 \\
--- \\
-\mathrm{C}-333 \mathrm{~B}\end{array}$ & 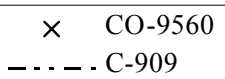 & $\begin{array}{cc}* & C-909 \\
- & -\end{array}$ \\
\hline
\end{tabular}

Figura 4 - Rendimento de grãos de milho (R, kg/ha) em função de doses crescentes de nitrogênio. Experimento 2. Data de semeadura: 29 de novembro de 2000. 


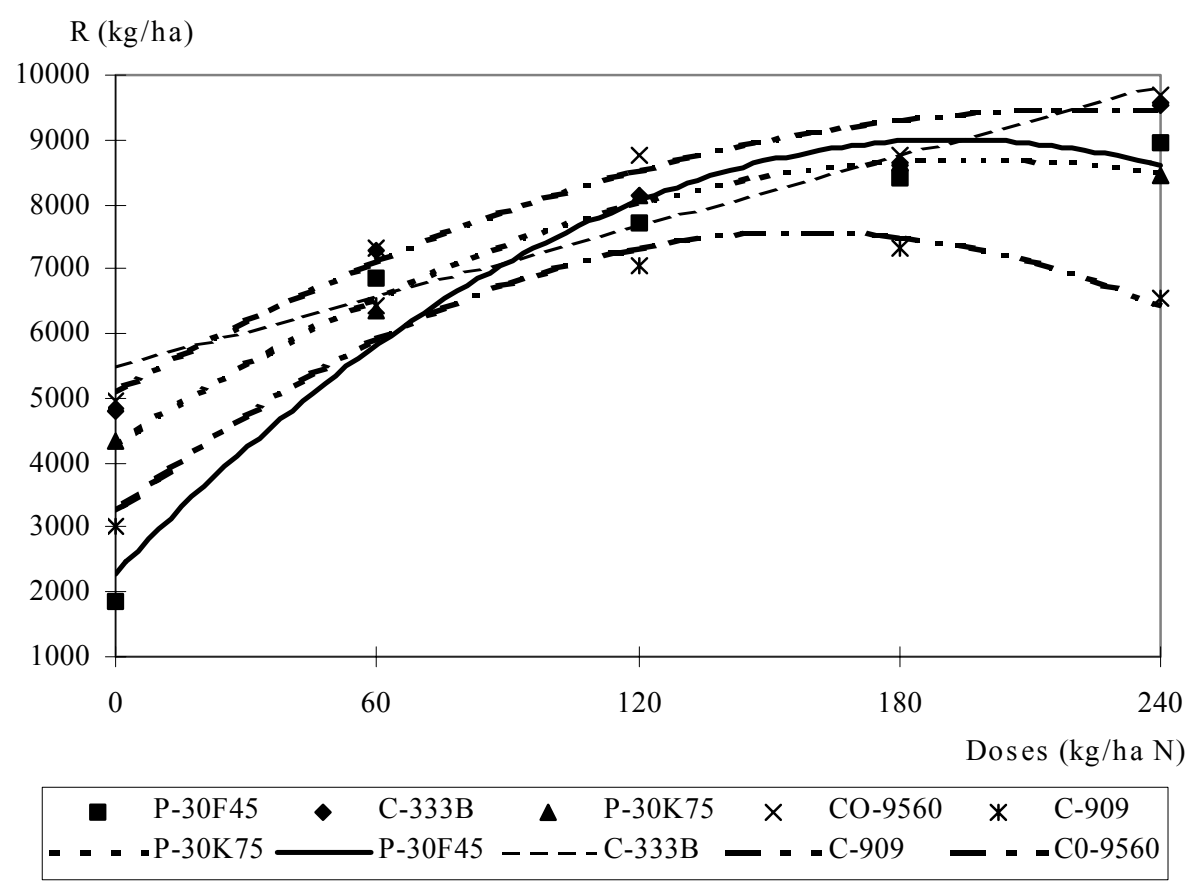

Figura 5 - Rendimento de grãos de milho $(\mathrm{R}, \mathrm{kg} / \mathrm{ha})$ em função de doses crescentes de nitrogênio. Experimento 3. Data de semeadura: 27 de dezembro de 2000.

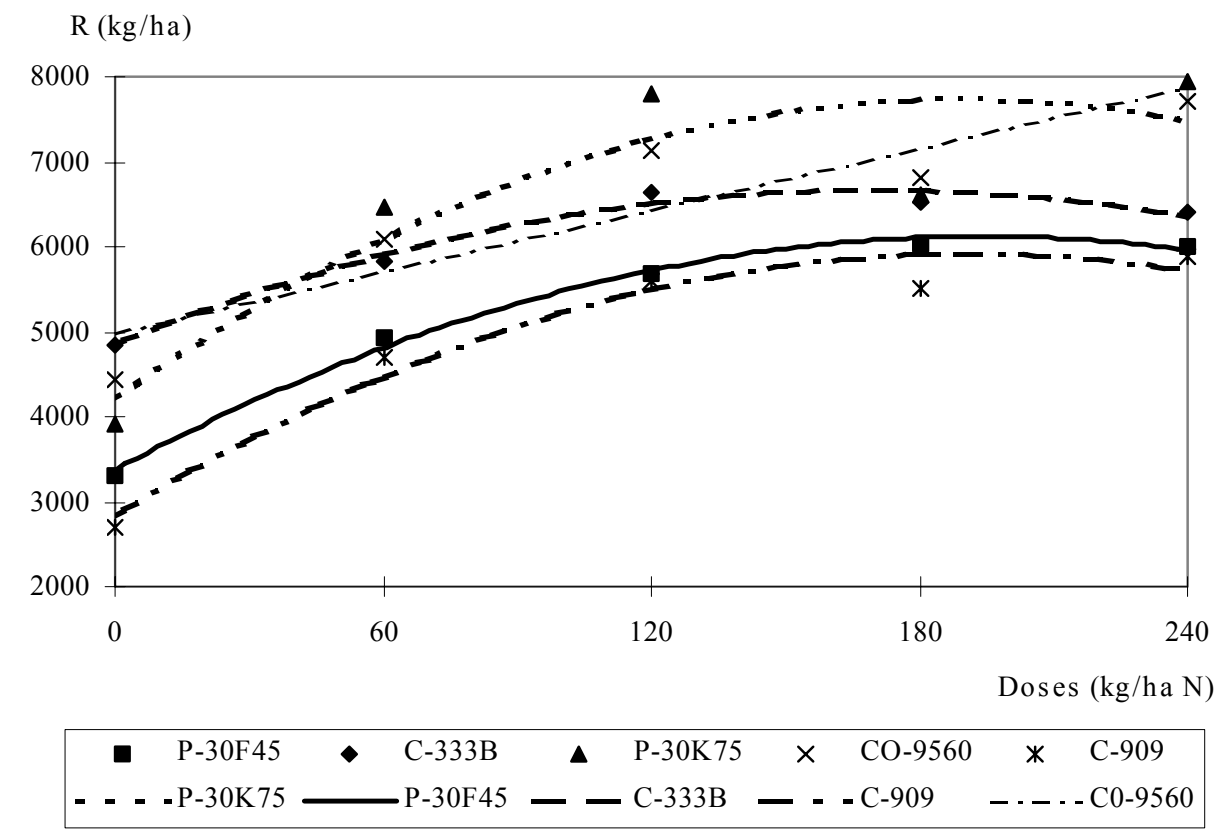

Figura 6 - Rendimento de grãos de milho $(\mathrm{R}, \mathrm{kg} / \mathrm{ha})$ em função de doses crescentes de nitrogênio. Experimento 4. Data de semeadura: 22 de fevereiro de 2001. 
Tabela 25. Rendimento médio de grãos $(\mathrm{kg} / \mathrm{ha})$, para cada genótipo em cada dose de nitrogênio, nos quatro experimentos (média de 3 repetições).

\begin{tabular}{|c|c|c|c|c|c|c|c|}
\hline \multirow{2}{*}{ Experimento } & \multirow{2}{*}{ Genótipo } & \multicolumn{5}{|c|}{ Dose (kg/ha) } & \multirow{2}{*}{ Média } \\
\hline & & 0 & 60 & 120 & 180 & 240 & \\
\hline \multirow{6}{*}{1} & P-30F45 & 4352,6 & 5942,9 & 7650,6 & 9878,8 & 12424,5 & 8049,9 \\
\hline & C-333B & 2694,4 & 5044,0 & 8246,9 & 10777,6 & 12291,9 & 7811,0 \\
\hline & P-30K75 & 4066,2 & 6171,9 & 9326,2 & 9826,4 & 11679,7 & 8214,1 \\
\hline & CO-9560 & 3720,0 & 6144,6 & 8775,3 & 10401,1 & 10241,7 & 7856,5 \\
\hline & C-909 & 3240,1 & 6282,6 & 8294,8 & 10530,2 & 12191,1 & 8107,8 \\
\hline & Média & 3614,7 & 5917,2 & 8458,8 & 10282,8 & 11765,8 & \\
\hline \multirow{6}{*}{2} & P-30F45 & 2663,4 & 4664,5 & 6916,8 & 8759,0 & 10726,4 & 6746,0 \\
\hline & C-333B & 3692,9 & 6220,8 & 7419,4 & 9349,9 & 10266,4 & 7389,9 \\
\hline & P-30K75 & 3601,8 & 5415,0 & 8315,3 & 9310,5 & 10257,5 & 7380,0 \\
\hline & CO-9560 & 3428,3 & 6163,1 & 7569,0 & 9269,3 & 9809,4 & 7247,8 \\
\hline & C-909 & 3228,4 & 5325,8 & 6870,8 & 8738,8 & 9448,6 & 6722,5 \\
\hline & Média & 3322,9 & 5557,8 & 7418,3 & 9085,5 & 10101,7 & \\
\hline \multirow{6}{*}{3} & P-30F45 & 1835,3 & 6859,9 & 7710,0 & 8402,3 & 8937,5 & 6749,0 \\
\hline & C-333B & 4783,4 & 7282,0 & 8145,0 & 8605,7 & 9540,8 & 7671,4 \\
\hline & P-30K75 & 4337,9 & 6353,3 & 8148,5 & 8654,7 & 8450,7 & 7189,0 \\
\hline & CO-9560 & 4942,9 & 7307,8 & 8770,4 & 8754,0 & 9672,5 & 7889,5 \\
\hline & C-909 & 3007,1 & 6437,7 & 7037,0 & 7325,3 & 6552,1 & 6071,8 \\
\hline & Média & 3781,3 & 6848,2 & 7962,2 & 8348,4 & 8630,7 & \\
\hline \multirow{6}{*}{4} & P-30F45 & 3318,8 & 4928,3 & 5692,6 & 6019,2 & 6011,0 & 5194,0 \\
\hline & C-333B & 4848,4 & 5839,4 & 6643,3 & 6530,5 & 6400,2 & 6052,3 \\
\hline & P-30K75 & 3909,2 & 6473,8 & 7791,4 & 6620,8 & 7938,3 & 6546,7 \\
\hline & CO-9560 & 4432,2 & 6084,4 & 7124,8 & 6813,7 & 7714,5 & 6433,9 \\
\hline & C-909 & 2688,0 & 4692,7 & 5605,2 & 5519,7 & 5889,1 & 4878,9 \\
\hline & Média & 3839,3 & 5603,7 & 6571,5 & 6300,8 & 6790,6 & \\
\hline
\end{tabular}

\subsubsection{Massa de 1.000 grãos}

As Figuras (Figura 7, Figura 8, Figura 9 e Figura 10) a seguir ilustram a variação da massa de 1000 grãos (g) em função de doses crescentes de nitrogênio nos quatro experimentos (dois locais em quatro épocas de semeadura).

A massa de 1.000 grãos é um parâmetro componente do rendimento de grãos. Para a maioria dos genótipos existentes no mercado, essa pode ser uma das maneiras de se 
caracterizar os genótipos. Após o florescimento principalmente, qualquer estresse, seja de natureza biótica ou abiótica que a cultura de milho se exponha, estará afetando a massa final de grãos. A incidência de doenças, que leva à seca prematura das folhas e consequentemente, redução do ciclo da planta, provoca queda acentuada no tamanho e peso de grãos (Pinto et al.,1997).

O parâmetro foi determinado em todos os experimentos no sentido de verificar diferenças existente entre os genótipos e sua variação devido ao efeito da aplicação de nitrogênio, nos diferentes tratamentos.

Observa-se que diferença significativas forma observadas para o efeito doses de nitrogênio, exceto para o experimento 3 (ANEXO B

Tabela 31, ANEXO B). Houve diferença significativa entre genótipos em todos os experimentos.

No experimento 1, verificou-se que os genótipos 1 (P-30F45) e 2 (C-333B) apresentaram efeito quadrático (1 FV: Fonte de variação.

2 GL: Graus de liberdade.

3 Prob: Probabilidade a nível de 5\%.

Tabela 32, ANEXO B) e os genótipos 3 (P-30K75) e 4 (CO-9560) efeito linear em função de doses de nitrogênio, para esse parâmetro (Figura 7). O genótipo 1 foi o que apresentou os maiores valores de massa de 1000 grãos, sendo verificada diferenças significativas em relação aos demais genótipos (Tabela 33, ANEXO B).

No segundo experimento (2), foi verificado efeito linear crescente apenas para o genótipo 1. As diferenças significativas entre os genótipos repetiram o comportamento do experimento 1 (Tabela 35, ANEXO). Nesse sentido, verifica-se que o genótipo 1 (P30F45), apresenta potencial positivo de resposta para tal parâmetro, em função de doses.

No experimento 3, o único genótipo que apresentou algum efeito significativo é demonstrado pela análise de regressão e refere-se novamente ao genótipo 1 (Tabela 36, ANEXO B). Na Tabela 37 (ANEXO B), podem ser observadas diferenças significativas entre os genótipos 2, 3 e 4 e o genótipo 1, que também diferiu em relação ao genótipo 5 .

Efeitos quadráticos são verificados em três genótipos (1, 2 e 5), no experimento 4 (Tabela 38, ANEXO B). O genótipo C-333B apresentou os maiores valores para o componente massa de 1000 grãos, genótipo esse que também apresentou o melhor desempenho de rendimento grãos para essa época. 


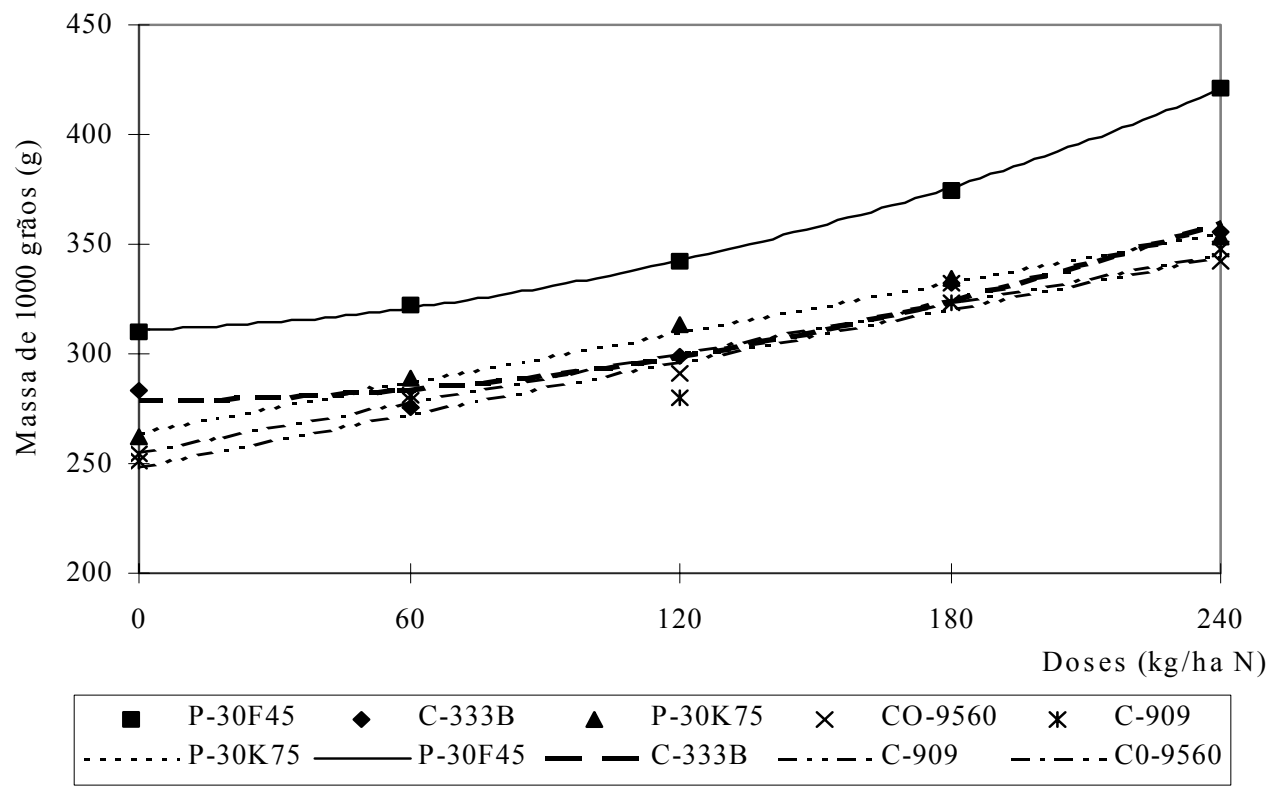

Figura 7 - Massa de 1000 grãos (g) em função de doses crescentes de nitrogênio. Experimento 1. Data de semeadura: 11 de setembro de 2000.

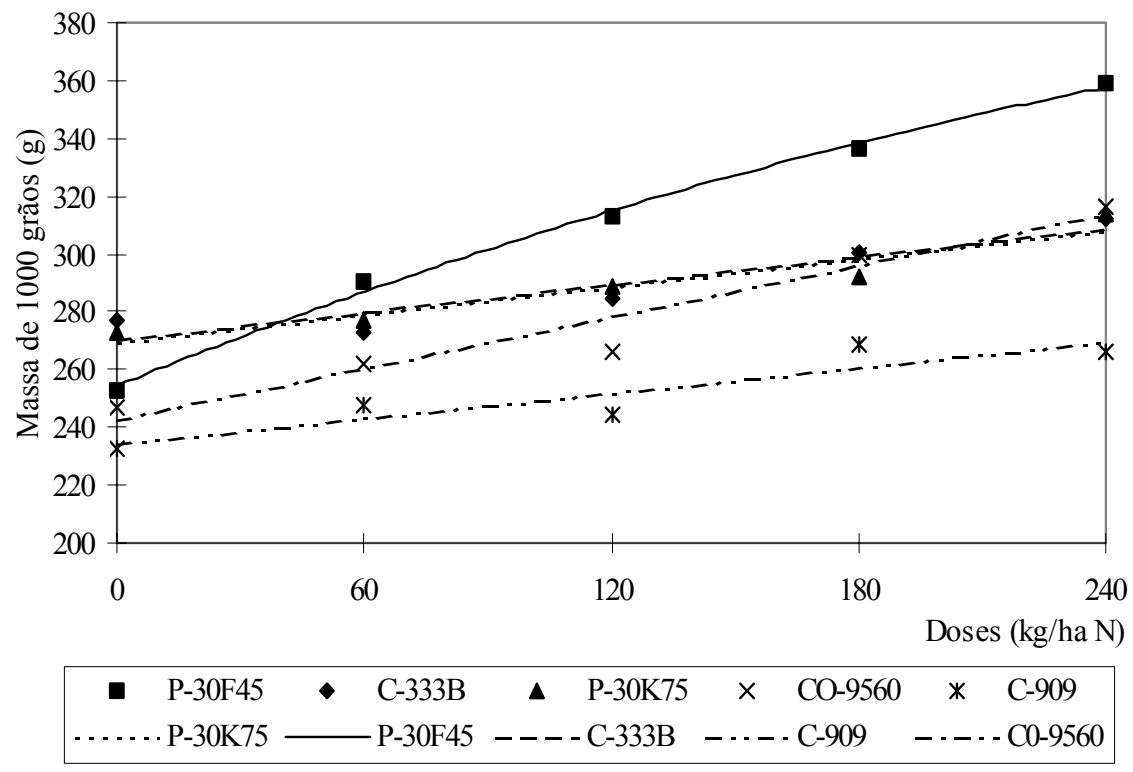

Figura 8 - Massa de 1000 grãos (g) em função de doses crescentes de nitrogênio. Experimento 2. Data de semeadura: 29 de novembro de 2000. 


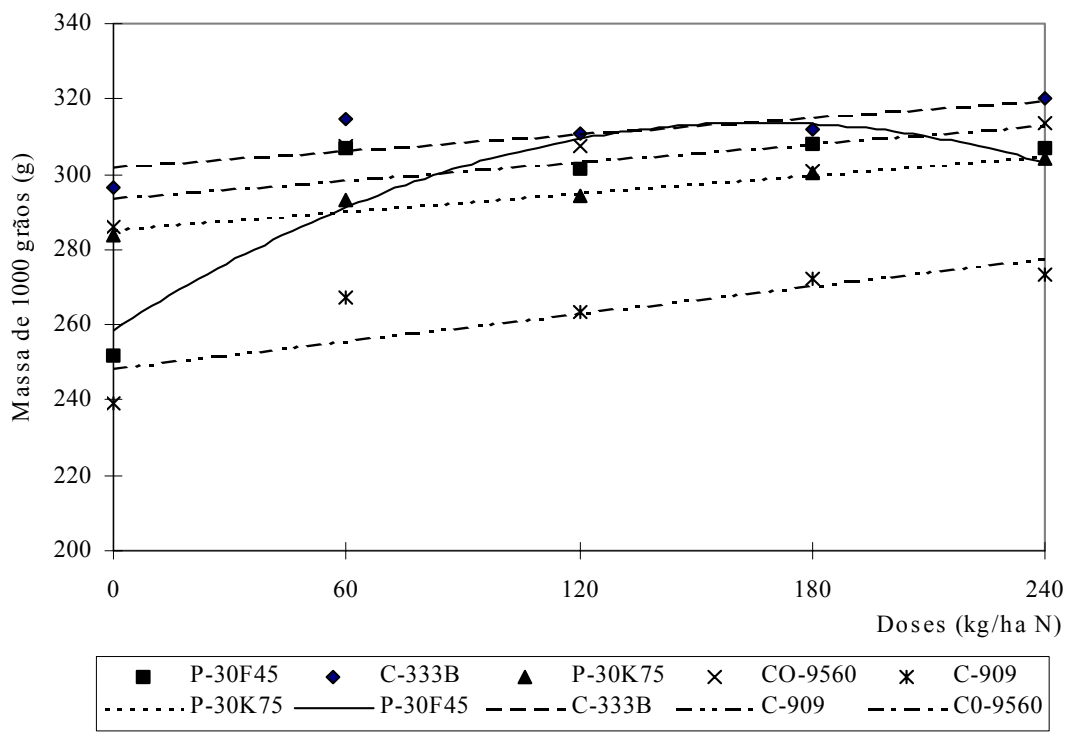

Figura 9 - Massa de 1000 grãos (g) em função de doses crescentes de nitrogênio. Experimento 3. Data de semeadura: 27 de dezembro de 2000.

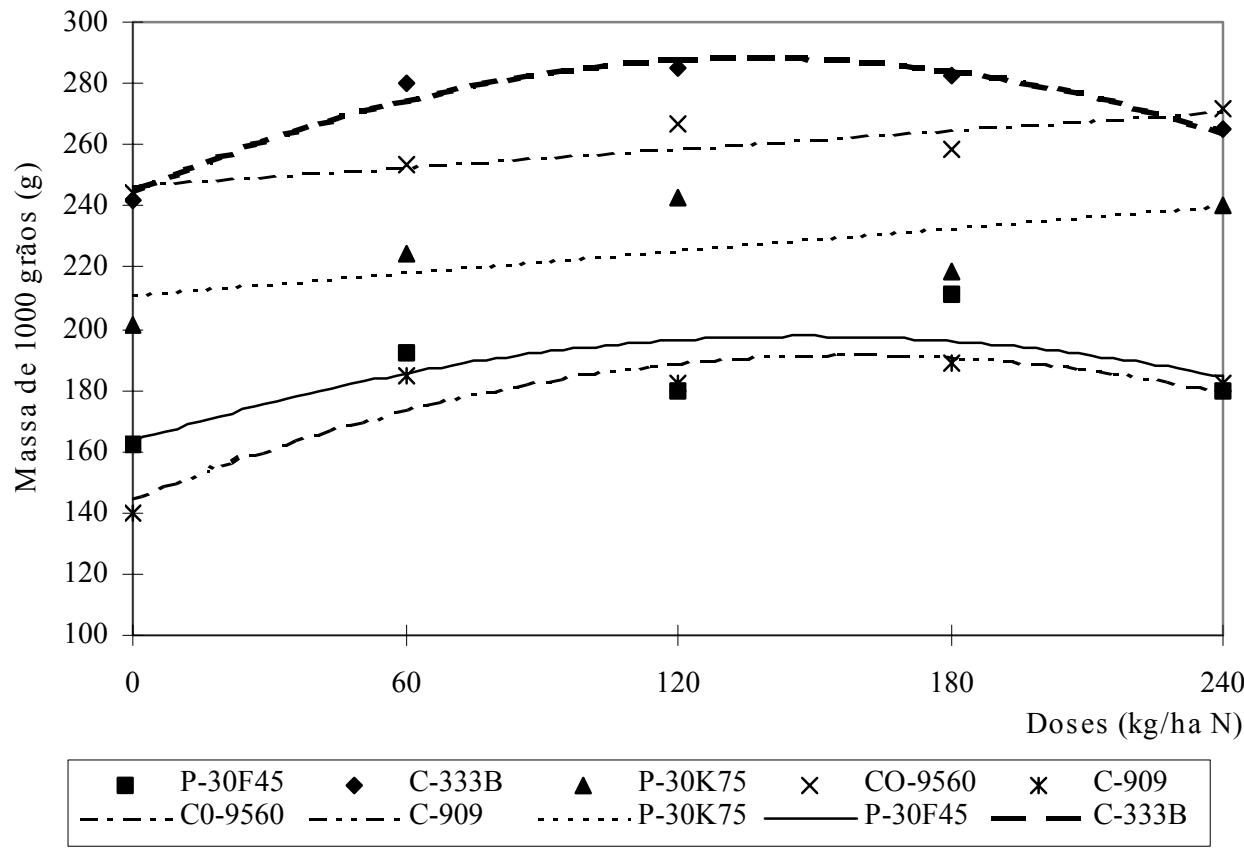

Figura 10 - Massa de 1000 grãos (g) em função de doses crescentes de nitrogênio. Experimento 4. Data de semeadura: 22 de fevereiro de 2001. 


\subsubsection{Teor de clorofila total}

O teor de clorofila total nas folhas foi uma avaliação complementar no sentido de comparar e acompanhar o desempenho das diferentes doses de nitrogênio aplicadas nos diferentes genótipos.

A identificação do comportamento do nitrogênio nos diferentes estádios de desenvolvimento da planta de milho é de extrema importância para explicar o sincronismo entre as necessidades de nitrogênio da cultura e a quantidade disponibilizada no solo.

Existem vários métodos que já foram propostos para caracterizar o crescimento e o desenvolvimento da cultura de milho, em relação ao nível de nitrogênio na planta. $\mathrm{O}$ monitoramento tem como objetivo acompanhar a aplicação do nutriente. $\mathrm{O}$ medidor portátil de clorofila é usado como uma técnica para se avaliar o nível de nitrogênio na planta em seus diferentes estádios, apresentando boa correlação com o rendimento de grãos e aceitável nível de precisão, sem a necessidade de destruição das folhas da planta (Argenta et al., 2000).

A leitura pelo clorofilômetro, dependendo do estádio da cultura, evidencia a existência de uma relação entre a leitura do clorofilômetro (Lc, leitura SPAD) e o teor de clorofila na folha (Tcf, $\mu \mathrm{g} / \mathrm{mg}$ ) (Marquard \& Tipton, 1987; Argenta et al., 2000), e o teor de clorofila e teor de nitrogênio na planta (Smeal \& Zhang, 1994).

Argenta et al. (2000) obtiveram as seguintes relações: (i) 6 a 7 folhas: Tcf $=-0,174+0,166 \mathrm{Lc}\left(\mathrm{r}^{2}=0,85\right)$; (ii) 10 a 11 folhas: Tcf=-3,872+0,226Lc $\left(\mathrm{r}^{2}=0,96\right)$; e (iii) pendoamento: $\mathrm{Tcf}=-4,455+0,228 \mathrm{Lc}\left(\mathrm{r}^{2}=0,83\right)$.

A adubação nitrogenada, quando subestimada, pode provocar redução no rendimento de grãos. Quando superestimada, poderá gerar redução na rentabilidade do produtor, além de desperdiçar desnecessariamente fertilizante, provocando prejuízos ao ambiente em função da lixiviação do nitrato.

\subsubsection{Experimento 1}

Ficou evidenciado nesse experimento, que o teor de clorofila na folha oposta e imediatamente inferior à espiga é maior, quanto maior for a dose de nitrogênio aplicada 
e menor a idade da planta (Figura 11). Sendo assim, um modelo matemático pôde ser obtido para descrever a variação temporal (dias após a emergência) do teor de clorofila na folha de milho em função da aplicação de doses crescentes de nitrogênio no solo (Figura 12 e Tabela 26).

Em função da observação do comportamento similar para os cinco híbridos comerciais utilizados (Experimento 1), assumiu-se que o modelo proposto é representativo para a cultura de milho.

Para a determinação do teor de clorofila na folha, utilizou-se a equação média obtida por Argenta et al. (2000) (Tabela 26).

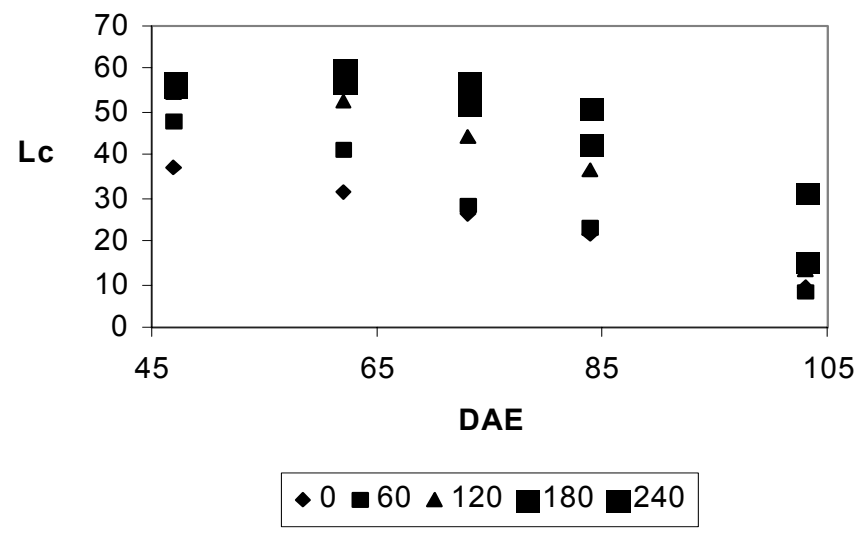

Figura 11 - Variação temporal (valores observados em função do número de dias após a emergência, DAE) da leitura do clorofilômetro (Lc, leitura SPAD) na folha de milho para as diferentes doses utilizadas de nitrogênio $(0,60,120,180$ e 240 $\mathrm{kg} / \mathrm{ha})$. 


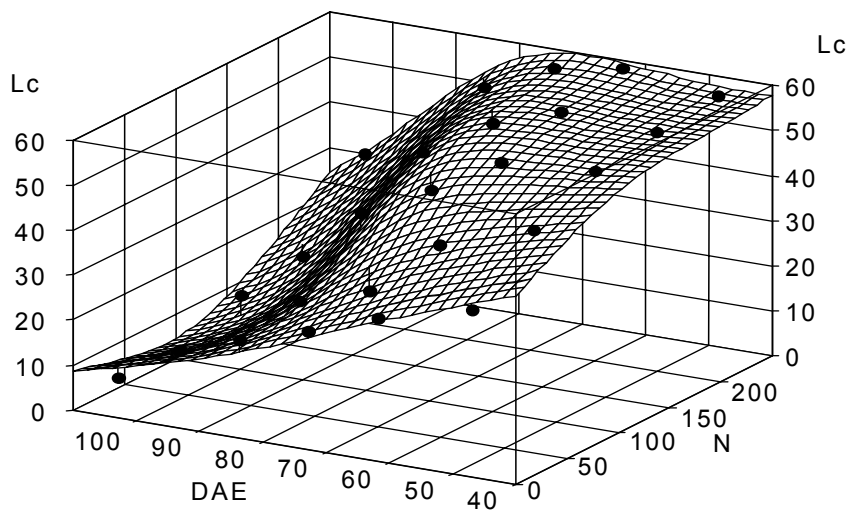

Figura 12 - Modelo descritor (Tabela 1) da variação temporal (Dias Após a Emergência, DAE) da leitura do clorofilômetro (Lc, leitura SPAD) de milho em função da adubação nitrogenada $(\mathrm{N}, \mathrm{kg} / \mathrm{ha})$.

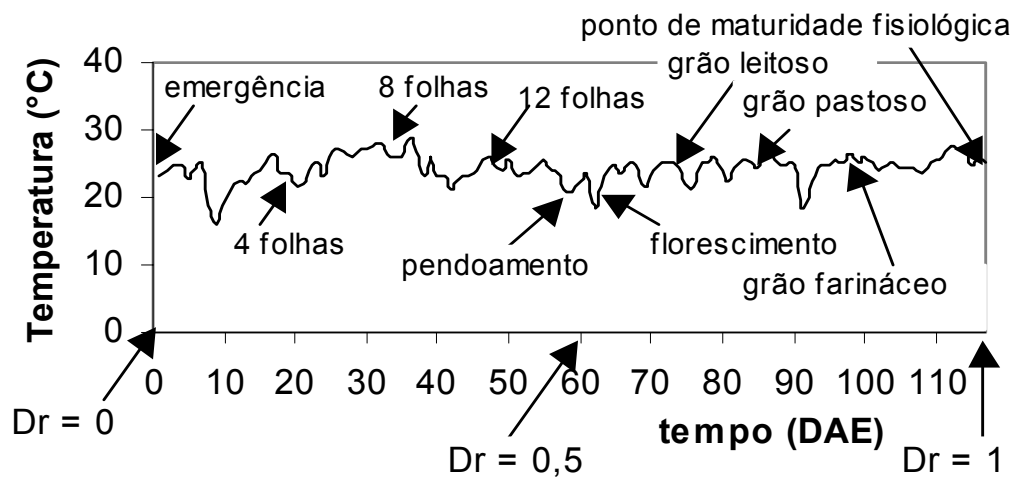

Figura 13 - Variação temporal da temperatura média do ar durante o ciclo da cultura de milho (dias após a emergência - DAE - e desenvolvimento relativo da cultura - Dr) (experimento 1). 
Tabela 26. Modelo descritor da variação temporal (Dr) do teor clorofila na folha (Tcf, $\mu \mathrm{g} / \mathrm{mg}$ ) de milho para as diferentes doses utilizadas de nitrogênio ( $\mathrm{N}, \mathrm{kg} / \mathrm{ha})$.

\begin{tabular}{|c|c|c|c|c|}
\hline \multirow{2}{*}{\begin{tabular}{|l} 
Modelo $^{1}$ \\
Parâmetro
\end{tabular}} & $\mathrm{Tcf}=-2,834+0,207$ & \multicolumn{3}{|c|}{$\frac{a+\text { b.N }+ \text { c. } N^{2}+119 \cdot d \cdot \operatorname{Dr}_{\mathrm{DAE}}+\mathrm{e} \cdot\left(119 \cdot \operatorname{Dr}_{\mathrm{DAE}}\right)^{2}+\mathrm{f} \cdot\left(119 \cdot \mathrm{Dr}_{\mathrm{DAE}}\right)^{3}}{1+\mathrm{g} \cdot \mathrm{N}+\mathrm{h} \cdot \mathrm{N}^{2}+\mathrm{i} \cdot \mathrm{N}^{3}+119 \cdot \mathrm{j} \cdot \mathrm{Dr} \mathrm{DAE}_{\mathrm{DAE}}}$} \\
\hline & Erro padrão & Valor t & \multicolumn{2}{|c|}{ Intervalo de confiança $(95 \%)$} \\
\hline $\mathrm{a}=58,37385115$ & 65,50902164 & 0,891081101 & $-82,2197241$ & 198,9674264 \\
\hline$b=-0,03397901$ & 0,076008817 & $-0,44704032$ & $-0,19710694$ & 0,129148927 \\
\hline$c=0,000176571$ & 0,000462226 & 0,382001191 & $-0,00081545$ & 0,001168588 \\
\hline$d=-1,55963808$ & 3,448291524 & $-0,45229299$ & $-8,96026202$ & 5,840985858 \\
\hline $\mathrm{e}=0,014713662$ & 0,050755797 & 0,289891254 & $-0,09421697$ & 0,123644291 \\
\hline$f=-4,699.10^{-5}$ & 0,000226799 & $-0,20718787$ & $-0,00053374$ & 0,000439759 \\
\hline $\mathrm{g}=-0,00216099$ & 0,003269064 & $-0,66104344$ & $-0,00917696$ & 0,004854978 \\
\hline$h=1,12627.10^{-5}$ & $2,22903.10^{-5}$ & 0,505272657 & $-3,6576 \mathrm{e} \cdot 10^{-5}$ & $5,91016.10^{-5}$ \\
\hline$i=-1,4763 \mathrm{e} \cdot 10^{-8}$ & $4,49002 \cdot 10^{-8}$ & $-0,32879238$ & $-1,1113.10^{-7}$ & $8,16007 \cdot 10^{-8}$ \\
\hline$j=-0,0198865$ & 0,014582157 & $-1,36375577$ & $-0,05118231$ & 0,011409305 \\
\hline$k=0,000120029$ & 0,000148577 & 0,807855553 & $-0,00019884$ & 0,0004389 \\
\hline Fonte de variação & Soma dos quadrados & Graus de liberdade & Quadrado médio & Valor F \\
\hline Regressão & 6437,5106 & 10 & 643,75106 & 77,5212 \\
\hline Erro & 116,2587 & 14 & 8,3041931 & \\
\hline Total & 6553,7693 & 24 & & \\
\hline
\end{tabular}

1 Coeficiente de determinação ajustado: 0.967

Optou-se por fazer uma única análise de regressão, utilizando-se dose de nitrogênio e dias após a emergência (DAE) como variáveis independentes, e a leitura do clorofilômetro como variável dependente. Pode-se utilizar, para efeito de extrapolação para outras localidades, o desenvolvimento relativo da cultura $\left(\mathrm{Dr}_{\mathrm{m}}\right.$ : relação entre a soma calórica acumulada até o m-ésimo dia após a emergência e a soma calórica referente ao ponto de maturidade fisiológica), dada pela seguinte expressão: $\operatorname{Dr}_{\mathrm{DAE}}=0,0084$. DAE (ou $\left.\mathrm{DAE}=119 . \mathrm{Dr}_{\mathrm{DAE}}\right)\left(\mathrm{r}^{2}=0,9994\right)$. 


\subsubsection{Experimentos 1, 2, 3 e 4}

As Figuras (Figura 14, Figura 15, Figura 16 e Figura 17) a seguir ilustram a relação entre as leituras SPAD, adubação nitrogenada, índice de severidade e rendimento de grãos.

Os aspectos a serem comentados sobre os dados, para os referidos experimentos, estão relacionados com o item anterior, onde ficou demonstrada a existência de uma relação direta entre leitura do clorofilômetro (leitura SPAD) com o teor de clorofila na folha (Tcf, $\mu \mathrm{g} / \mathrm{mg}$ ), e o teor de clorofila com o teor de nitrogênio na planta, evidenciando-se assim, uma razoável confiabilidade do monitoramento através do clorofilômetro.

Um outro destaque que merece consideração, refere-se ao índice de severidade causada por P. maydis, que se correlacionou muito bem com as leituras SPAD. O fato foi observado efetuando-se as avaliações no mesmo estádio fenológico (estádio 8) para todos os experimentos (ANEXO B

Tabela 31, ANEXO B), ao qual pôde ser evidenciado que para aqueles genótipos considerados susceptíveis, em associação com a ocorrência da doença como demonstrado anteriormente, houve diminuição de área foliar.

Nos experimentos 1 e 2, não houve diferença significativa entre genótipos, nem tampouco efeito quadrático para o efeito doses. Apenas os genótipos 3 e 4 apresentaram efeito linear em relação a esse fator no experimento 1 (1 FV: Fonte de variação.

2 GL: Graus de liberdade.

3 Prob: Probabilidade a nível de 5\%.

Tabela 32, ANEXO B). No experimento 2, o genótipo 1 apresentou efeito linear, além dos genótipos 3 e 4 (Tabela 34, ANEXO B), sendo que os genótipos 2 e 5 diferiram linearmente do genótipo 1 (Tabela 35; ANEXO B).

No experimento 3, observou-se diferença significativa entre os genótipo 1 e o genótipo 2; entre o genótipo 2 e os genótipos 3, 4 e 5 (Tabela 37, ANEXO B), sendo que o genótipo 2 apresentou valores superiores da leitura SPAD, por ser um material de ciclo mais longo e consequentemente, de senescência mais tardia.

No experimento 4, o genótipo 2 também apresentou os valores superiores para essa fase (estádio), que diferiram dos valores do genótipo 4 e do genótipo 5. Houve também diferenças entres os valores dos genótipos 3 e 4 para o genótipo 5 e ainda entre 
o genótipo 1 aos demais, indicando que os menores valores foram para os genótipos 1 e 5, para esse estádio.

Nesse sentido, a antecipação do período para a senescência das plantas foi inevitável, podendo-se afirmar que quanto menor for a área foliar sadia durante a fase de enchimento de grãos, menor será a taxa fotossintética que, para Godoy et al.(1998a), foi inversamente à severidade da doenças observada. 

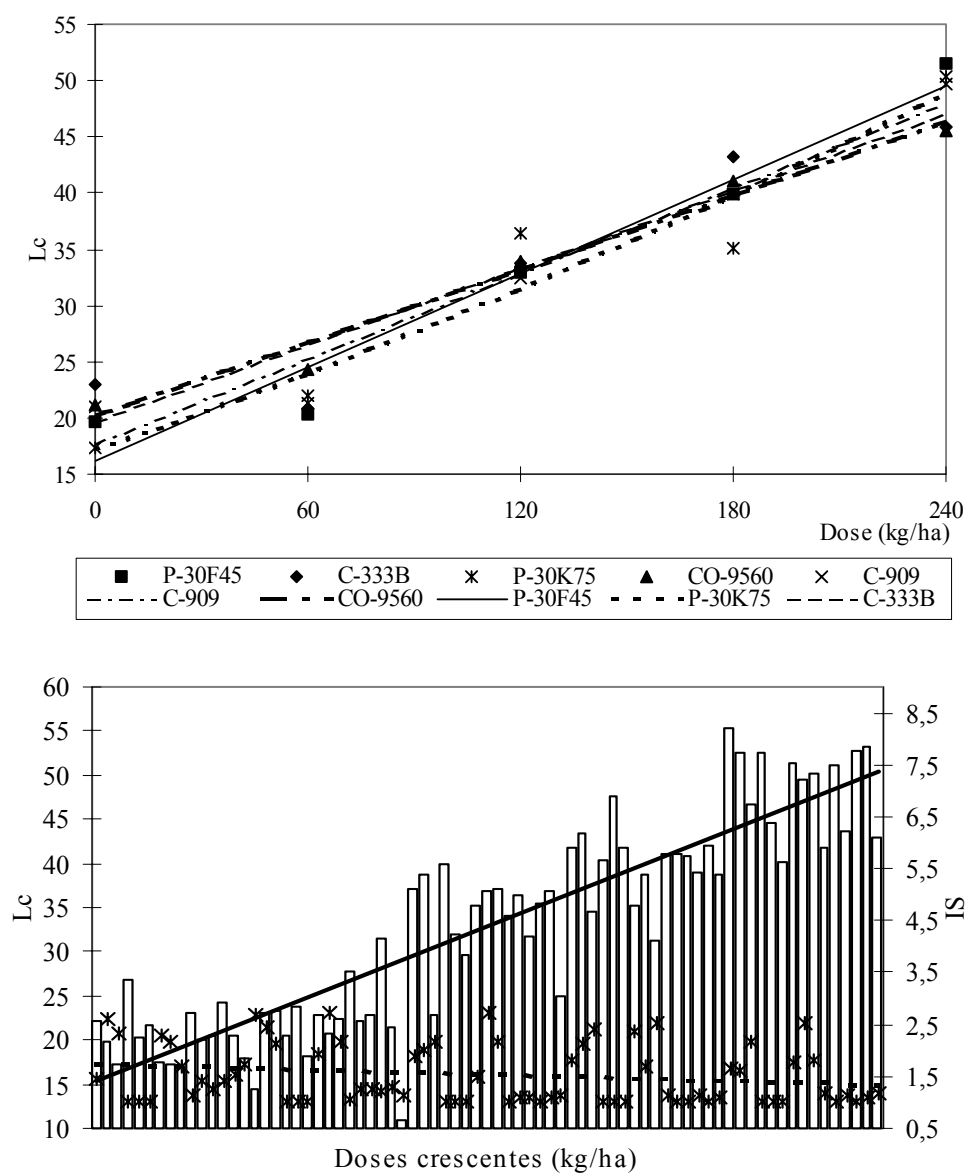

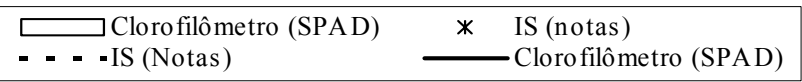

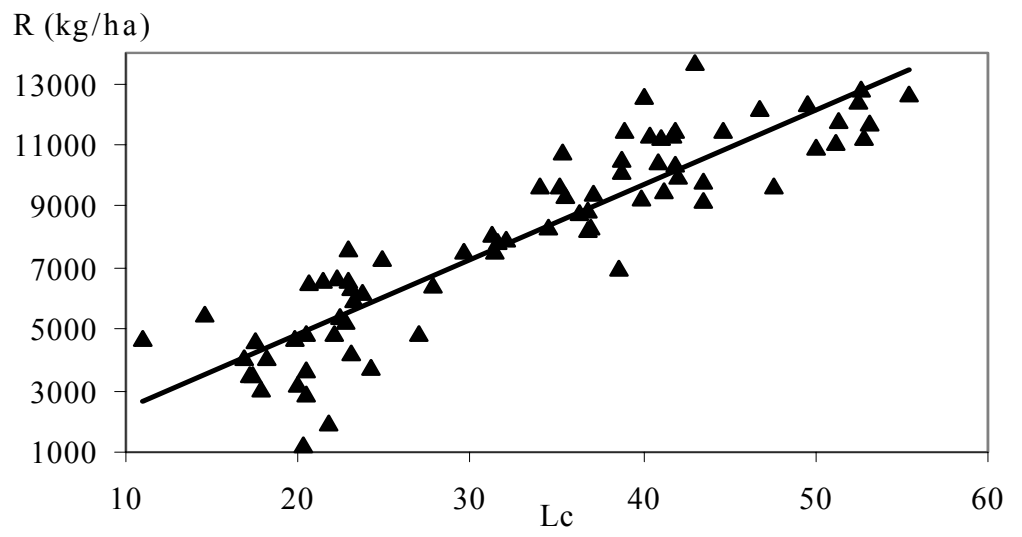

Figura 14 - Relação entre leitura SPAD (Clorofilômetro, Lc), doses crescentes de nitrogênio, índice de severidade e rendimento de grãos de milho (Experimento 1). 

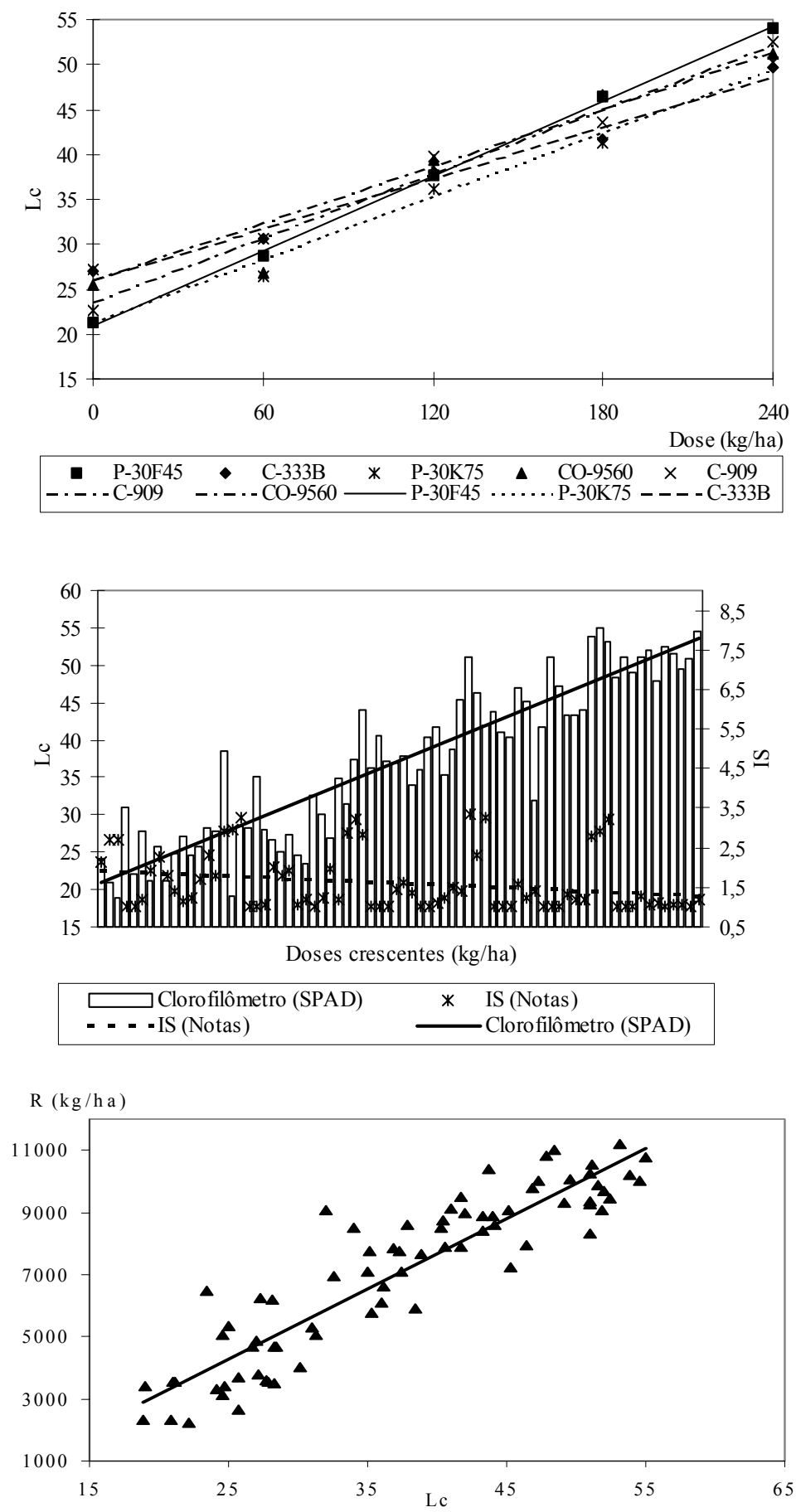

Figura 15 - Relação entre leitura SPAD (Clorofilômetro, Lc), doses crescentes de nitrogênio, índice de severidade e rendimento de grãos de milho (Experimento 2). 

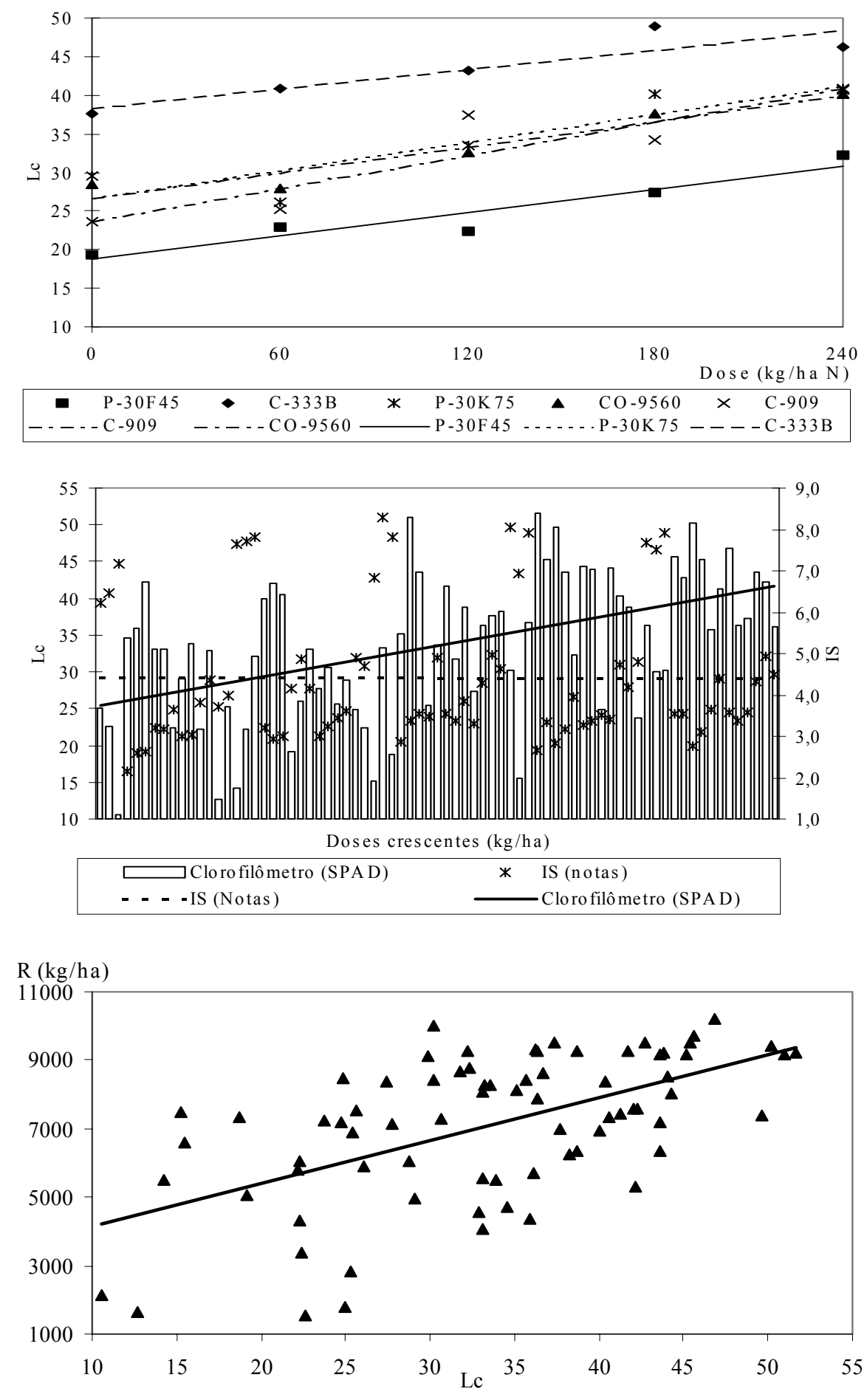

Figura 16 - Relação entre leitura SPAD (Clorofilômetro, Lc), doses crescentes de nitrogênio, índice de severidade e rendimento de grãos de milho (Experimento 3). 

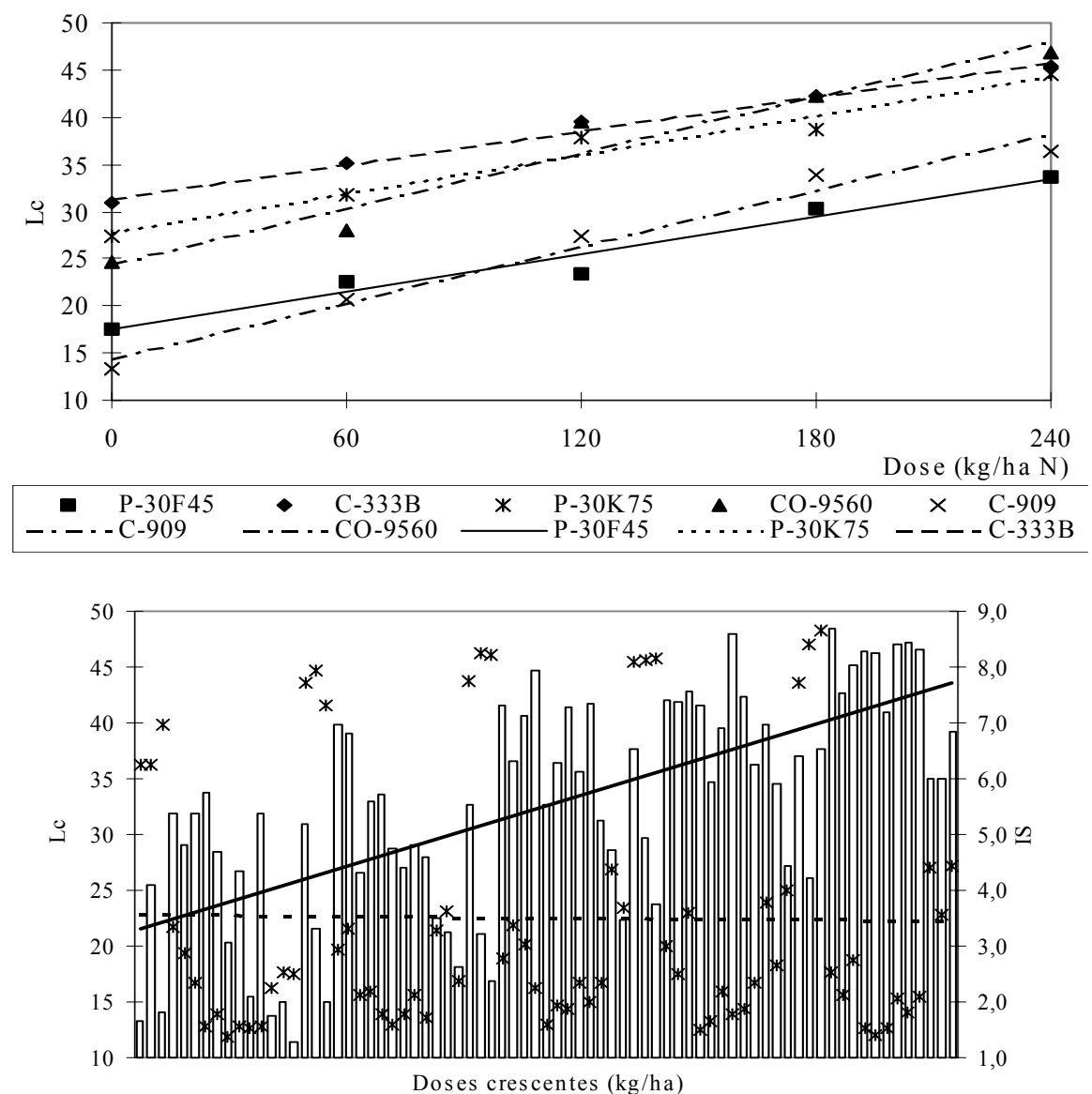

Doses crescentes $(\mathrm{kg} / \mathrm{ha})$
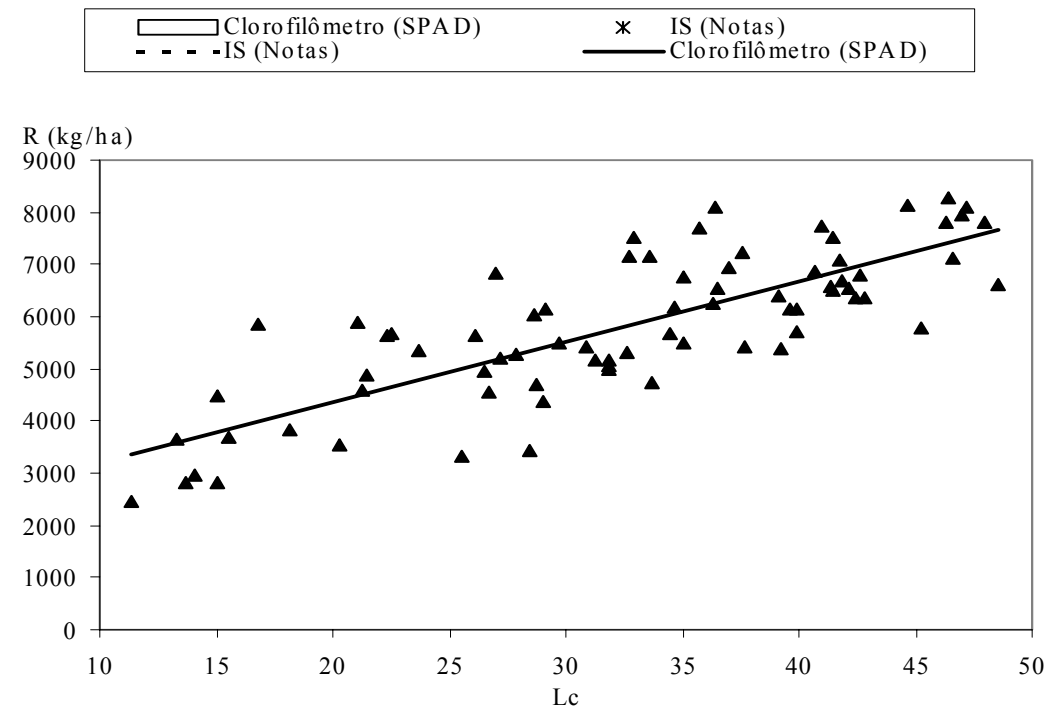

Figura 17 - Relação entre leitura SPAD (Clorofilômetro, Lc), doses crescentes de nitrogênio, índice de severidade e rendimento de grãos de milho (Experimento 4). 


\subsection{Incidência e severidade de $P$. maydis}

As Figuras a seguir ilustram a variação do índice de severidade (IS) causada por $P$. maydis em função de doses crescentes de nitrogênio nos quatro experimentos (duas localidades em quatro ambientes ou épocas de semeadura). Em cada experimento, os dados apresentados na Figura 18, Figura 19, Figura 20 e Figura 21 são referentes sempre à última avaliação, que pode contar com a presença de 3, 3, 2 e 2 avaliadores, respectivamente.

O que pode ser observado no experimento 1 é que apesar da existência da presença do patógeno na referida área experimental, as condições de temperatura e umidade verificadas (Tabela 30) no referido período não favoreceram o desenvolvimento da doença. Foram constatadas poucas lesões na parte superior à inserção da espiga, em apenas dois dos genótipos (P-30F45 e P-30K75), por ocasião do período compreendido entre os estádios fenológicos 8 e 9 (avaliação aos 98 DAE) da cultura. Não houve variação significativa no índice de severidade entre doses de nitrogênio (ANEXO B Tabela 31, ANEXO B). A diferença observada entre os genótipos citados (Tabela 33, ANEXO B) não representou prejuízos às folhas das plantas, sendo que a nota média recebida representa, na escala diagramática, o equivalente a $2,5 \%$ de área foliar com pontos de lesionados.

No experimento 2, a situação das condições climáticas não se repetem, porém também não são favoráveis ao desenvolvimento do patógeno. Por outro lado, houve diferença significativa para o fator dose de nitrogênio. A diferença significativa entre os índices de severidade relacionados aos genótipos se refere somente ao material susceptível (P-30F45), a qual foi verificada aos 100 DAE (Tabela 34 e Tabela 35, ANEXO B). O índice médio recebido representa o equivalente a $10 \%$ de área foliar lesionada das folhas superiores à inserção da espiga, o que praticamente não afetou o processo final de enchimento de grãos. Por outro lado, alguns autores observaram influência da doença no rendimento, mesmo sob baixa severidade de P. maydis (Fantin, et al. 2000)

Nos experimentos 3 e 4, o desempenho da severidade foi diferenciado em relação à situação anterior. Potencialmente, a localidade é considerada como referência para a 
ocorrência da doença, tanto pela elevada pressão que o patógeno exerce sobre a cultura, como pelas características climáticas favoráveis para o pleno desenvolvimento do fungo, principalmente considerando os ambientes estudados.

No experimento 3 (Figura 20), podem ser observadas diferenças estatísticas entre doses aplicadas de nitrogênio (ANEXO B

Tabela 31, ANEXO B) para os índices de severidade (IS) dos genótipos P-30F45 e P30K75 (Tabela 36, ANEXO B). Os demais genótipos apresentaram efeito linear quando considerado o fator dose de nitrogênio. $\mathrm{O}$ genótipo 1 diferiu significativamente em relação aos demais genótipos para o IS; diferiram entre si também o genótipo 2 e os genótipos 3, 4 e 5 e entre o genótipo 4 e o genótipo 5 houve diferença significativa.

Pelo resultado exposto acima, pode-se dizer que o genótipo 1 (P-30F45), confirmou sua susceptibilidade à doença e genótipo 5 foi o menos tolerante à doença.

Deve ser salientado que para esse experimento, houveram 3 avaliações. Uma primeira aos 54 dias após a emergência (florescimento médio), uma segunda 17 dias após o florescimento e uma terceira 34 dias após o florescimento.

A diferença significativa verificada para o índice de severidade entre os genótipos está relacionada com o material genético susceptível, que aos 34 dias após o florescimento alcançava valores entre 7 e 8 . Esses valores revelam uma equivalência de mais $75 \%$ da área foliar para uma fase coincidente com a fase de enchimento de grãos do genótipos. Em média, para os demais genótipos, valores dos índices de severidade estiveram variando entre 3 e 5 , indicando que a pressão do patógeno afetou praticamente todos os genótipos considerados tolerantes a doença.

No experimento 4, para o genótipo susceptível (P-30F45), diferença significativa entre os índices de severidade (variação entre 7,0 e 8,5) foi verificada para o fator doses de nitrogênio. Os valores indicam que houve um crescimento da doença em função de doses crescentes de nitrogênio (Tabela 38, ANEXO B). Nesse experimento, os genótipos P-30K75 e CO-9560 obtiveram índices médios de severidade variando entre 2,0 e 2,5, e os genótipos C-333B e C-909 valores variando entre 3,0 e 4,5 aos 90 dias após a emergência. 


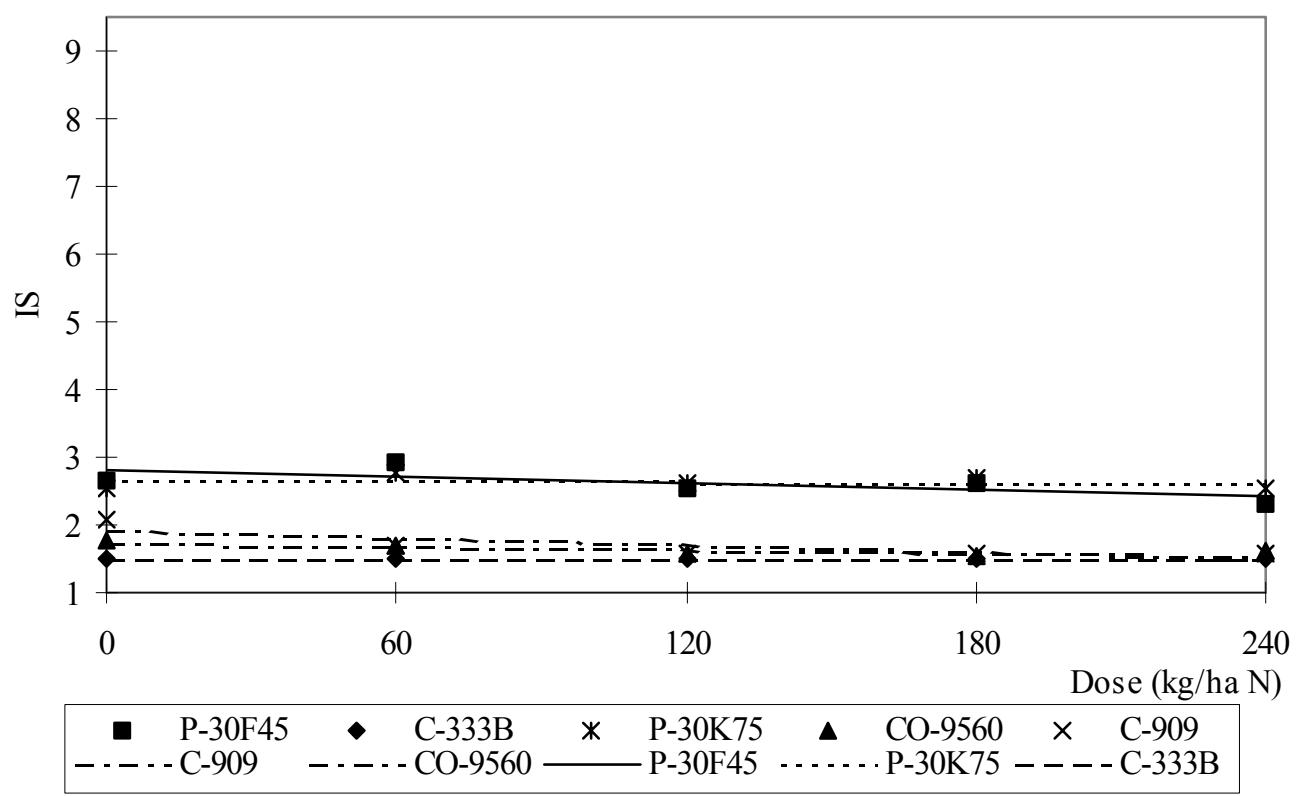

Figura 18 - Índice de severidade de P. maydis (IS) em função de doses crescentes de nitrogênio. Experimento 1 (avaliação aos 98 dias após a emergência).

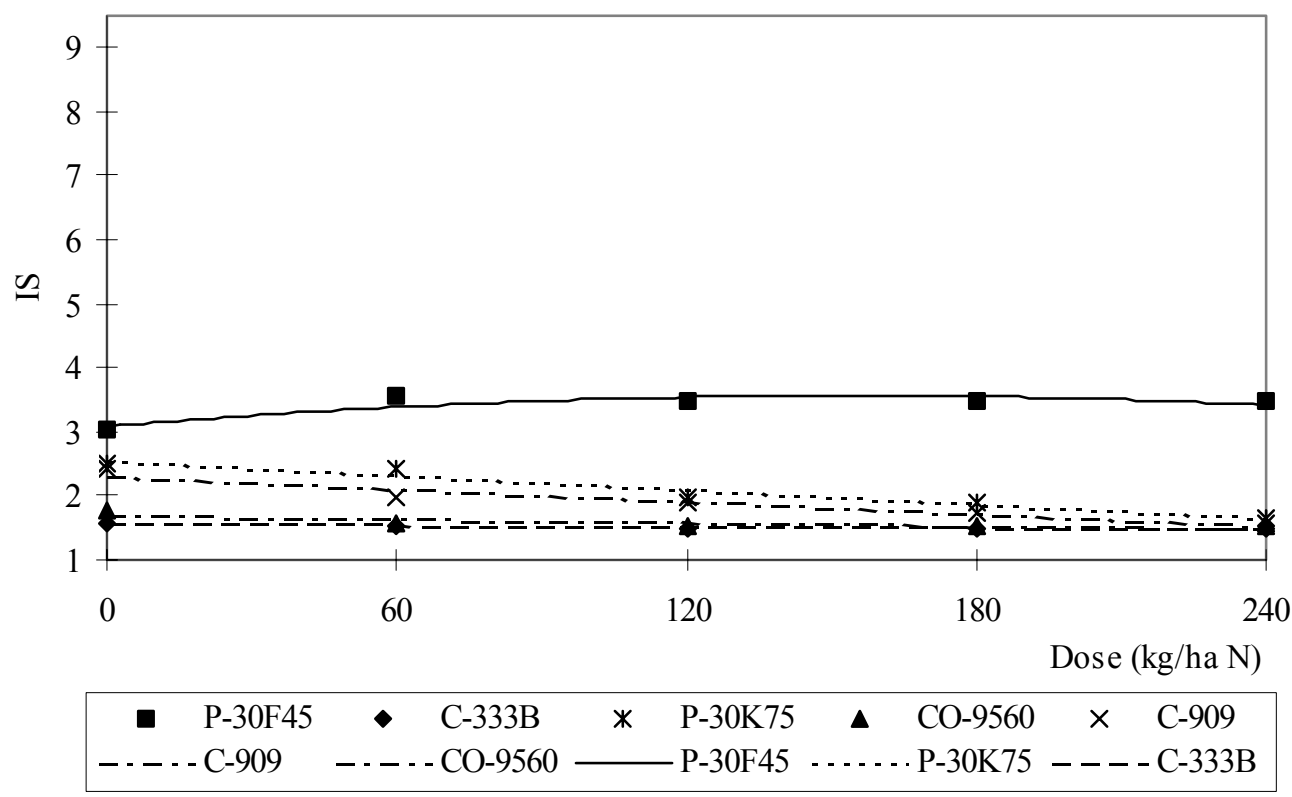

Figura 19 - Índice de severidade de P. maydis (IS) em função de doses crescentes de nitrogênio. Experimento 2 (avaliação aos 100 dias após a emergência). 


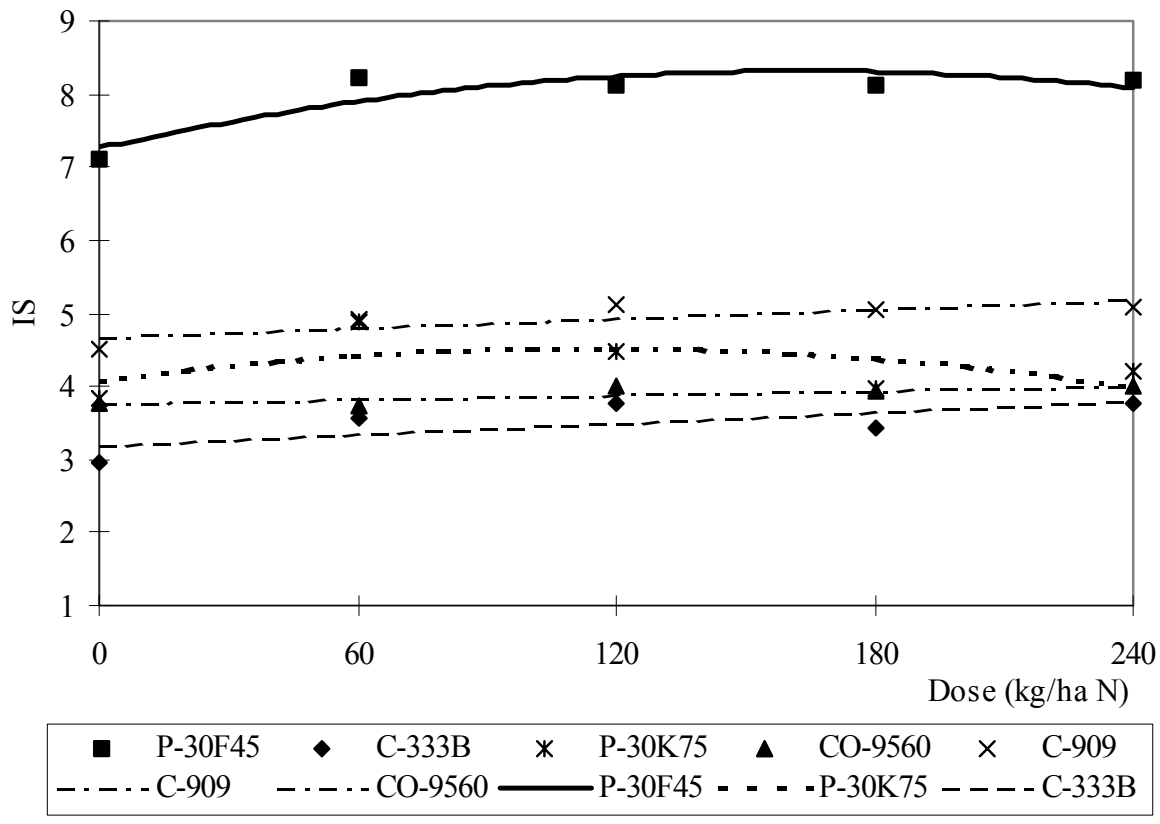

Figura 20 - Índice de severidade de P. maydis (IS) em função de doses crescentes de nitrogênio. Experimento 3 (avaliação aos 88 dias após a emergência).

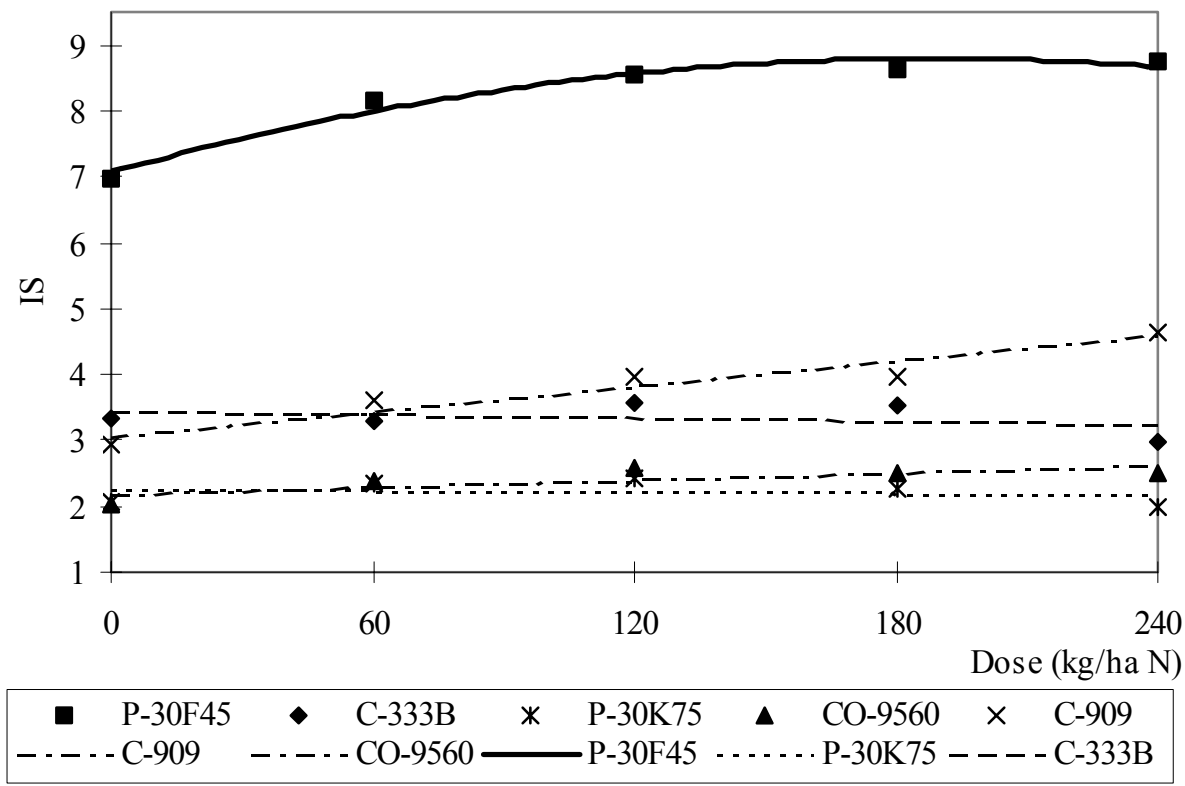

Figura 21 - Índice de severidade de P. maydis (IS) em função de doses crescentes de nitrogênio. Experimento 4 (avaliação aos 90 dias após a emergência). 


\subsection{Rendimento de grãos e índice de severidade por genótipo}

Para efeito de verificação da correlação do rendimento de grãos com o índice de severidade causado por $P$. maydis, pôde ser demonstrado graficamente, o comportamento individual dos genótipos em função da mudança da época de semeadura (efeito de ambientes) e em função das doses crescentes de nitrogênio.

$\mathrm{Na}$ Figura 22, correspondente ao genótipo 1 (P-30F45), pode ser observado o potencial de resposta do material genético por ocasião das semeaduras antecipadas que apresentaram condições climáticas favoráveis para o bom desenvolvimento das plantas. O material respondeu muito bem em função da adubação nitrogenada, principalmente em doses elevadas. Ainda, por ser um genótipo altamente susceptível à doença causada por $P$. maydis, em semeadura tardia, o mesmo não deve ser recomendado para essa situação, apesar de não apresentar uma queda muito acentuada no seu potencial produtivo em detrimento da severidade da doença. Nesse sentido, deve ser ressaltado que o material apresenta plantas bastante vigorosas que podem suportar situações adversas de estresse, tanto por suas estruturas de reserva que se desenvolvem rapidamente durante a fase vegetativa, como pelo curto período que necessita para completar a mencionda fase.

A confirmação do estudo verificado por Parentoni et al. (1996), pode ser observado na Figura 23, para o genótipo susceptível, que em função do acréscimo da quantidade de nitrogênio aplicada ocorre uma tendência de crescimento da severidade da doença ( $P$. maydis). O uso de doses adequadas de nitrogênio deve ser um fator importante no manejo da doença, sendo que o screening de genótipos, principalmente aqueles considerados tolerantes a $P$. maydis, deve ser feito preferencialmente utilizando níveis elevados de nitrogênio para se obter máxima expressão dos efeitos do sintomas da doença.

O genótipo 2 (C-333B), considerado um material de florescimento normal e "tolerante" à severidade da doença (classificação comercial), apresentou rendimento médio estável ao longo das diferentes épocas de semeadura para os diferentes tratamentos (Figura 24), o qual respondeu muito bem às doses elevadas nas semeaduras antecipadas. Porém, na dose de $120 \mathrm{~kg} / \mathrm{ha}$, o material obteve resultados muito próximos 
da média do genótipo para as quatro épocas. Salienta-se que na "safrinha" (experimento 4), sob doses elevadas de nitrogênio, o genótipo sofreu forte pressão de doenças da espiga (doenças fúngicas) que, segundo Marschner (1986), são favorecidas pelo aumento da concentração de aminoácidos livres e de amidas no apoplasto e na superfície foliar. O autor afirma que esse aumento, aparentemente, possui maior influência na germinação e no desenvolvimento dos conídios associada a condições de elevada umidade relativa do ar. Nesse sentido, isso explicaria o desenvolvimento das podridões (doenças da espiga) mencionadas, pelo maior período que o genótipo levou para atingir o ponto de maturidade fisiológica, prejudicando assim, sensivelmente o rendimento final de grãos (Figura 25).

O desempenho do genótipo 3 (P-30K75), em função das épocas de semeadura, é representado pela Figura 26. O material apresentou rendimento médio estável nas diferentes épocas, valor médio do índice de severidade à doença $P$. maydis em torno de 2, mesmo sob forte pressão do patógeno, o que pode ser observado no experimento 3 (valores médios do índice de severidade entre 3 e 4 ). $\mathrm{O}$ genótipo respondeu muito bem à adubação nitrogenada (Figura 27), principalmente para os ambientes (experimentos $1 \mathrm{e}$ 2) onde foram observadas condições climáticas favoráveis.

As mesmas observações feitas para o genótipo 3 são válidas para o genótipo 4 (CO-9560) (Figura 28 e Figura 29), com exceção da aplicação de doses elevadas de nitrogênio, em que o material genético não apresenta potencial de resposta. Por outro lado, o genótipo apresenta menores valores médios de IS ( $P$. maydis) em relação aos demais genótipos. Foi ainda observada uma tendência de menor incidência de outras doenças nos diferentes ambientes.

O híbrido C-909 (genótipo 5) foi o mais inadequado para o cultivo em semeaduras tardias (experimentos 3 e 4), tanto pela inadequação do genótipo ao ambiente, como pela baixa tolerância à $P$. maydis (Figura 30 ). Por outro lado, salienta-se que a referida inadequação deve ser devido a alta susceptibilidade do material à algumas viroses do complexo enfezamento, verificadas nos experimentos 3 e 4 . Nesse sentido, pôde ser constatada, baixa resposta à adubação nitrogenada e redução do rendimento de grãos (Figura 31). 


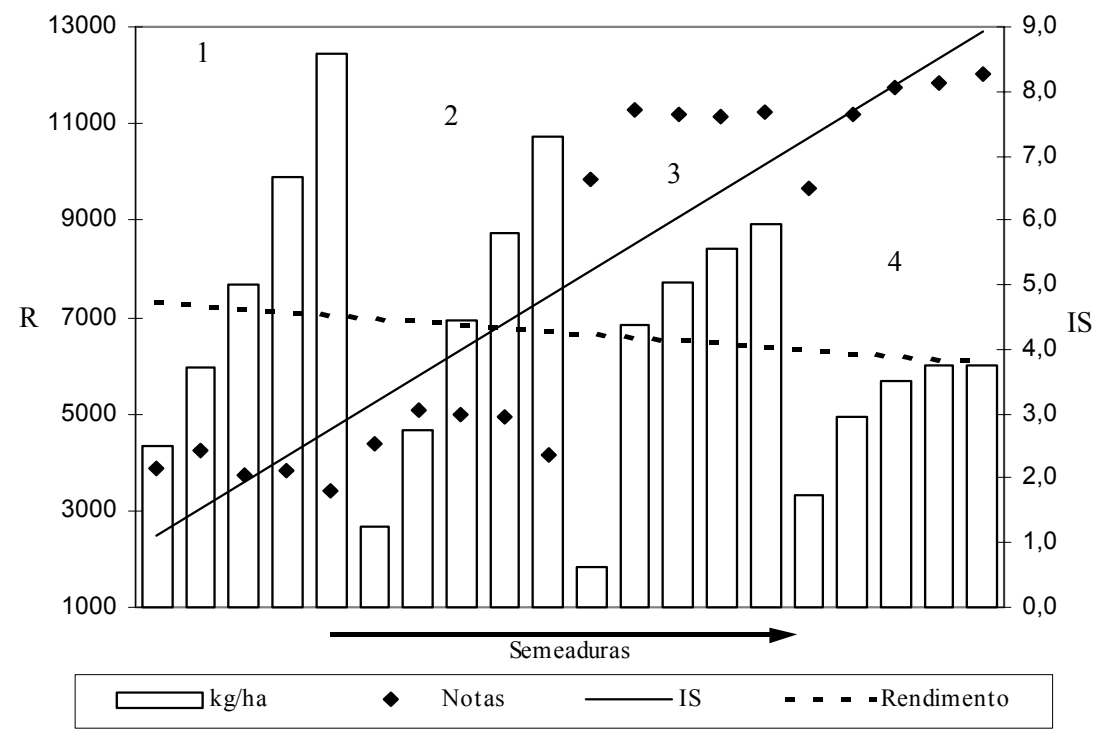

Figura 22 - Rendimento de grãos (R, kg/ha) e índice de severidade de P. maydis (IS) referentes ao genótipo 1 (P-30F45) em função do efeito das diferentes épocas de semeadura (efeito de ambientes) e doses de nitrogênio. Experimentos 1, 2, 3 e 4.

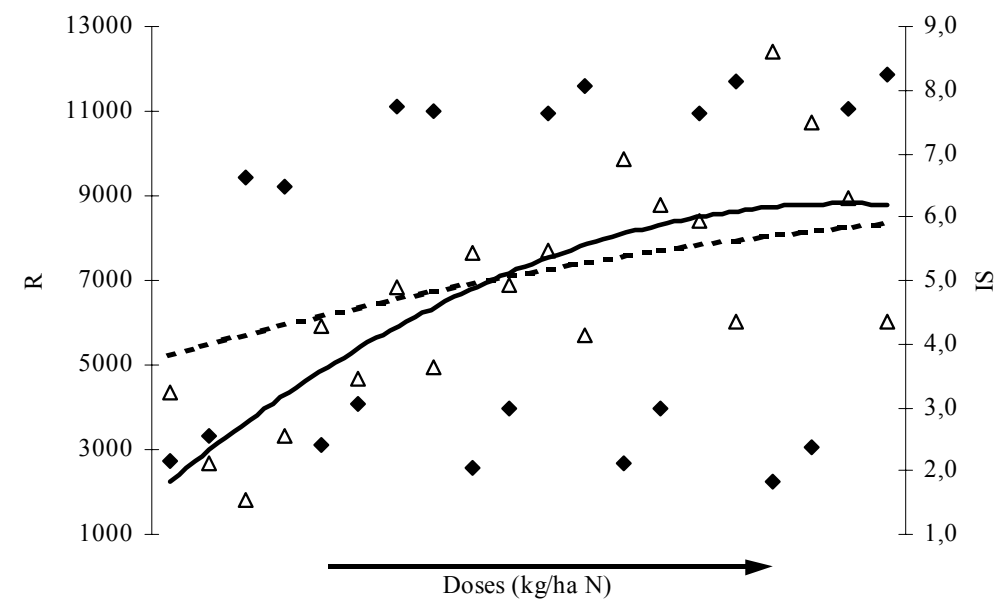

$\Delta \quad \mathrm{kg} / \mathrm{ha}$

Notas

$-\cdot-\cdot$ IS

Rendimento

Figura 23 - Rendimento de grãos (R, kg/ha) e índice de severidade de P. maydis (IS) referentes ao genótipo 1 (P-30F45) em função de doses crescentes de nitrogênio, nos quatro experimentos (efeito de dose). 


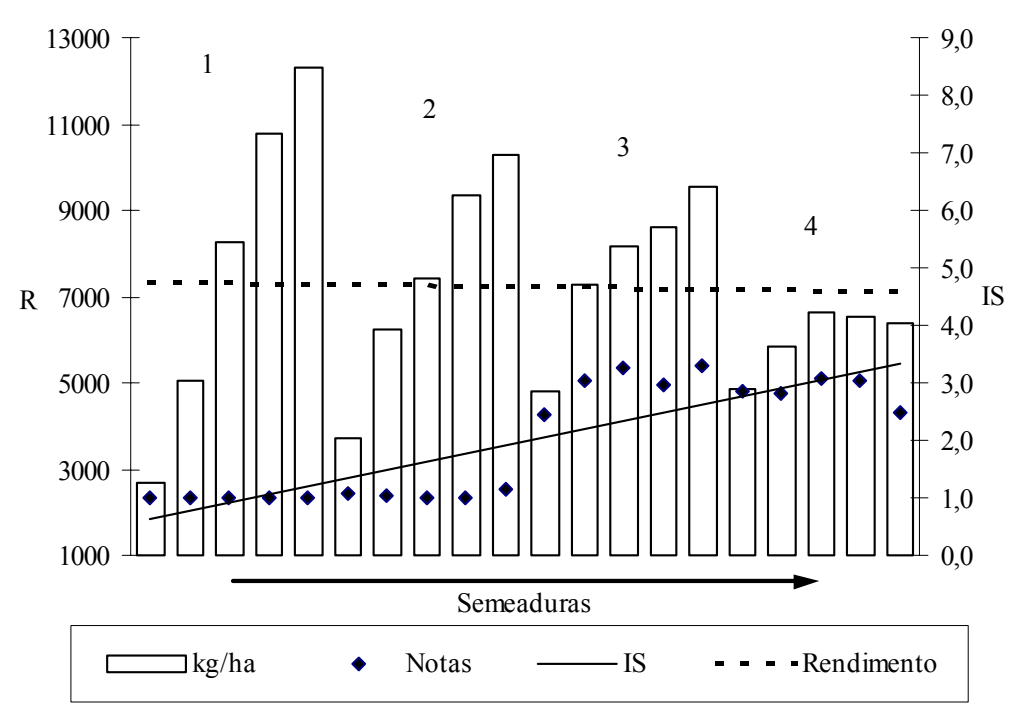

Figura 24 - Rendimento de grãos (R, kg/ha) e índice de severidade de $P$. maydis (IS) referentes ao genótipo 2 (C333-B) em função do efeito das diferentes épocas de semeadura (efeito de ambientes) e doses de nitrogênio. Experimentos 1, 2, 3 e 4.

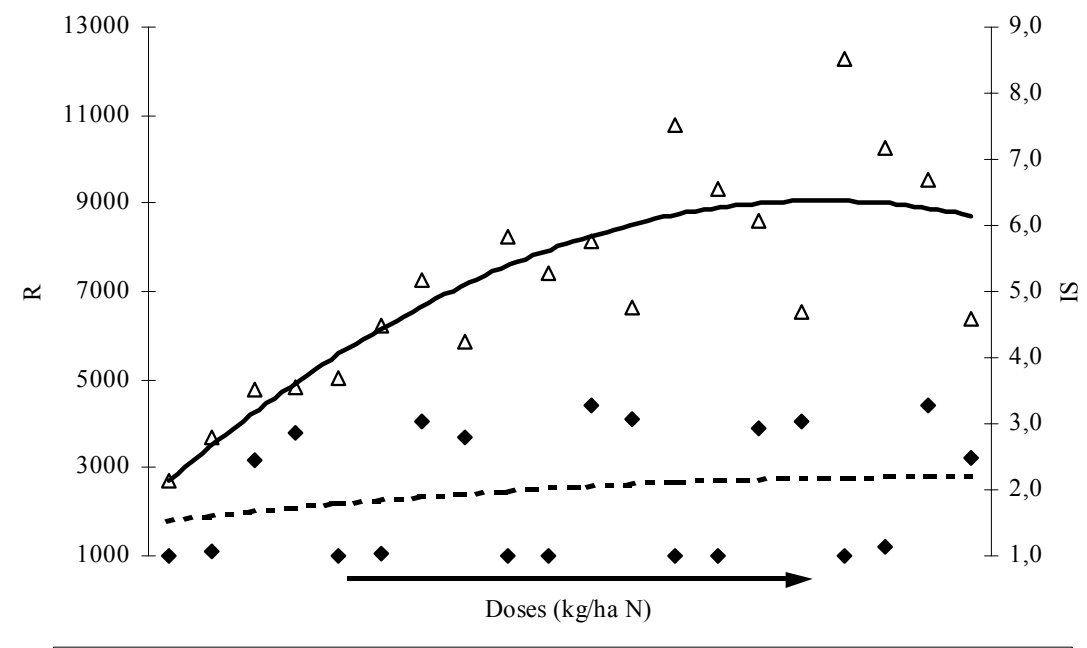

$\Delta \mathrm{kg} / \mathrm{ha} \quad \bullet \quad$ Notas $\quad$ - - - IS Rendimento

Figura 25 - Rendimento de grãos (R, kg/ha) e índice de severidade de P. maydis (IS) referentes ao genótipo 2 (C333-B) em função de doses crescentes de nitrogênio nos quatro experimentos (efeito da dose). 


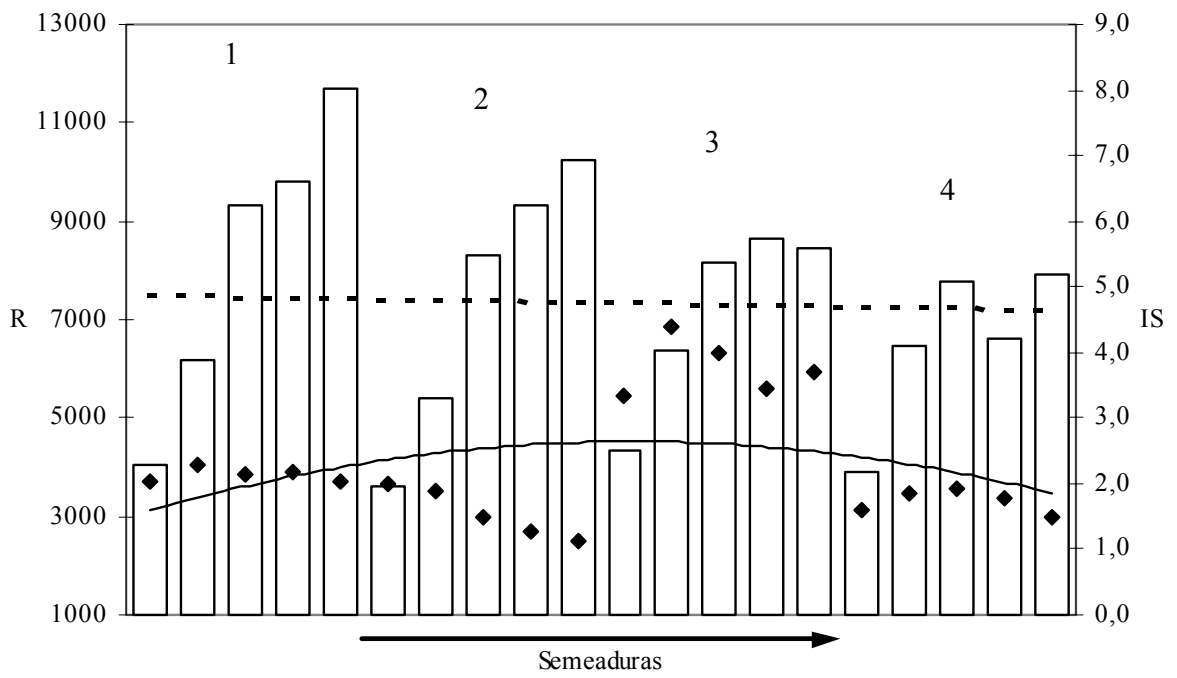

$\square_{\text {kgha }} \quad$ Notas $\quad-$ IS $\quad-\cdot$ - -Rendimento

Figura 26 - Rendimento de grãos (R, $\mathrm{kg} / \mathrm{ha}$ ) e índice de severidade de P. maydis (IS) referentes ao genótipo 3 (P-30K75) em função do efeito das diferentes épocas de semeadura (efeito de ambientes) e doses de nitrogênio. Experimentos 1, 2, 3 e 4 .

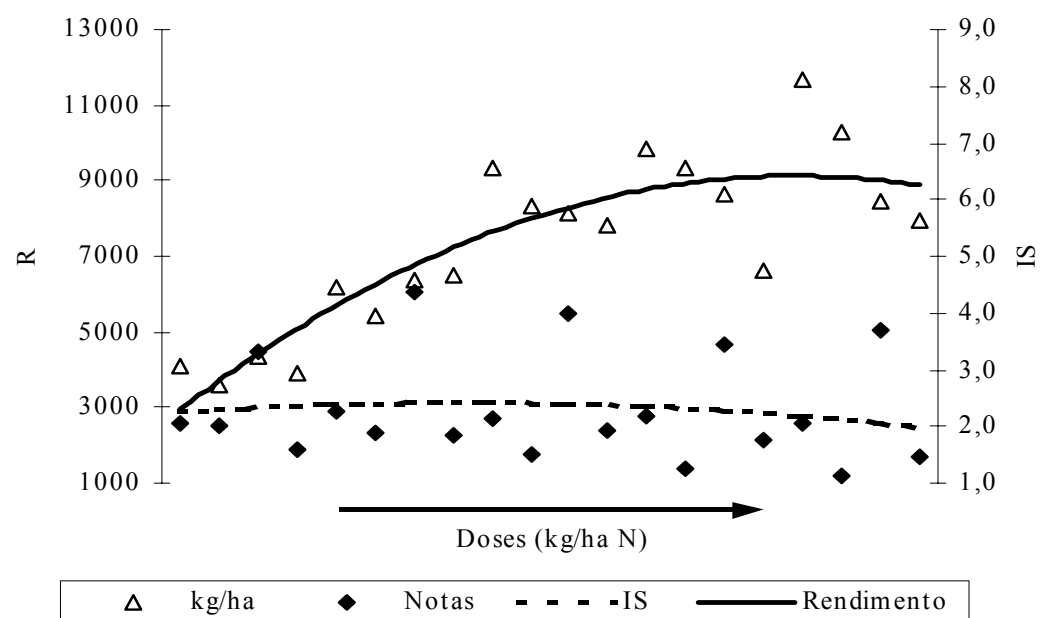

Figura 27 - Rendimento de grãos (R, kg/ha) e índice de severidade de $P$. maydis (IS) referentes ao genótipo 3 (P-30K75) em função de doses crescentes de nitrogênio nos quatro experimentos (efeito da dose). 


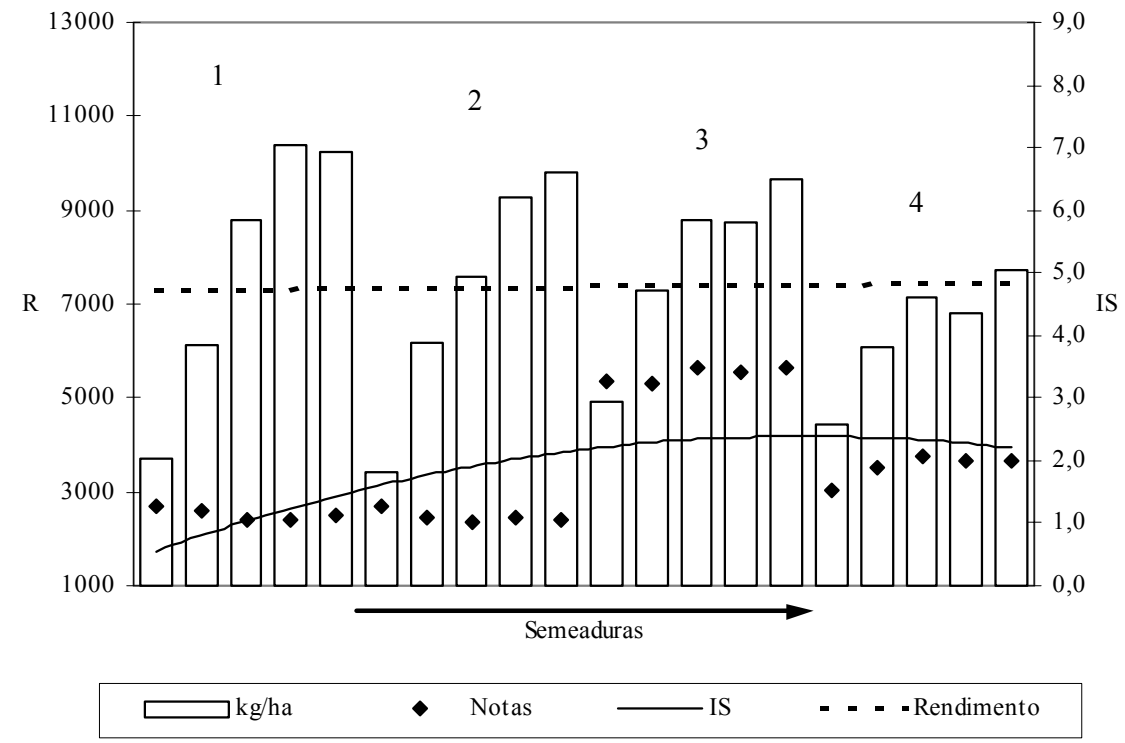

Figura 28 - Rendimento de grãos (R, kg/ha) e índice de severidade de P. maydis (IS) referentes ao genótipo 4 (CO-9560) em função do efeito das diferentes épocas de semeadura (efeito de ambientes) e doses de nitrogênio. Experimentos 1, 2, 3 e 4.

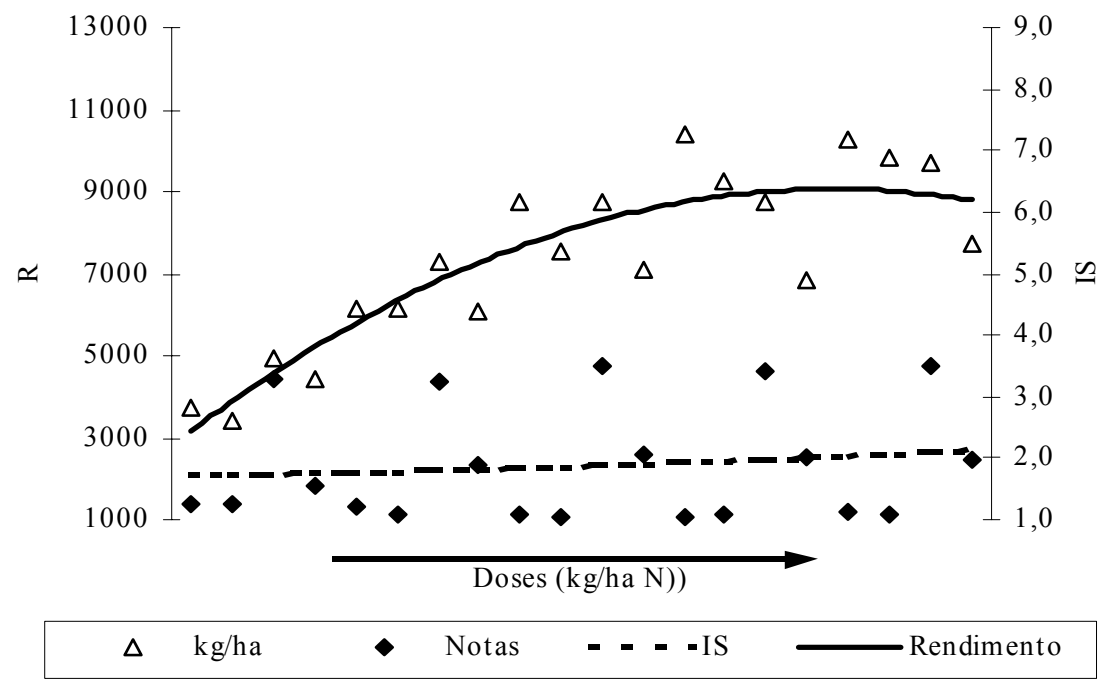

Figura 29 - Rendimento de grãos (R, kg/ha) e índice de severidade de $P$. maydis (IS) referentes ao genótipo 4 (CO-9560) em função de doses crescentes de nitrogênio nos quatro experimentos (efeito da dose). 


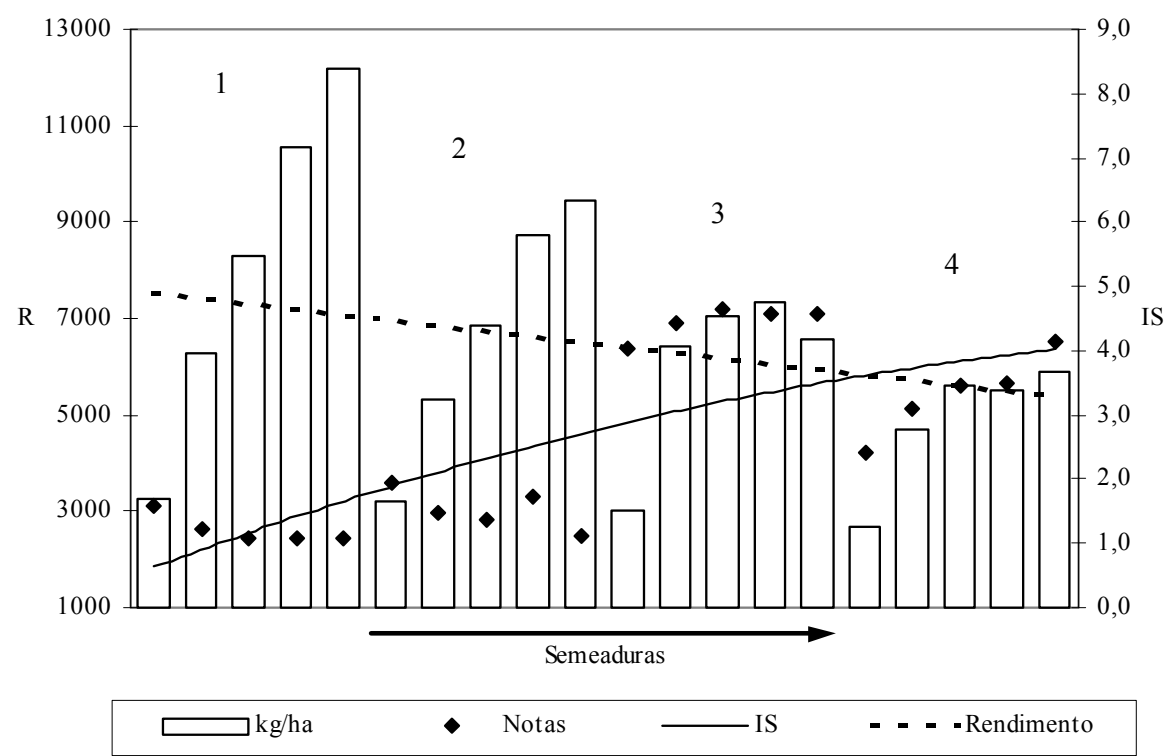

Figura 30 - Rendimento de grãos (R, kg/ha) e índice de severidade de $P$. maydis (IS) referentes ao genótipo 5 (C-909) em função do efeito das diferentes épocas de semeadura (efeito de ambientes) e doses de nitrogênio. Experimentos 1, 2, 3 e 4.

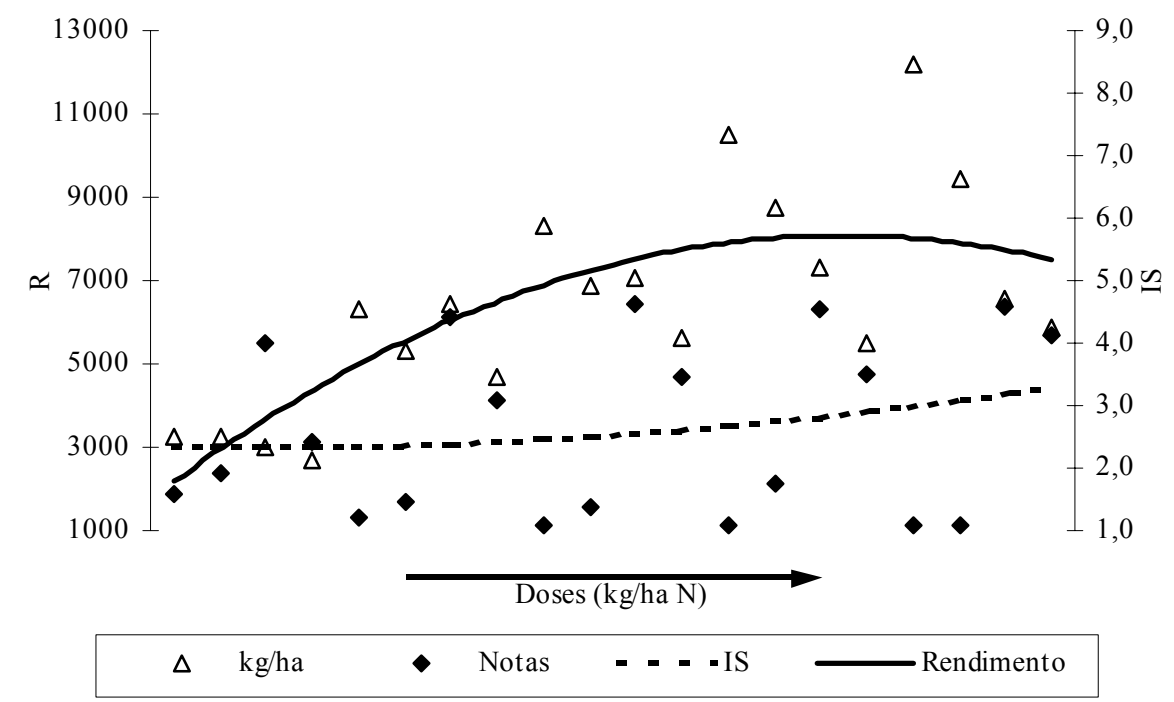

Figura 31 - Rendimento de grãos (R, kg/ha) e índice de severidade de P. maydis (IS) referentes ao genótipo 5 (C-909) em função de doses crescentes de nitrogênio nos quatro experimentos (efeito da dose). 


\subsection{Interação entre genótipo e ambiente}

A Tabela 27 apresenta o resultado da análise conjunta da variância referente aos dados de rendimento de grãos $(\mathrm{kg} / \mathrm{ha})$ dos cinco genótipos avaliados, em combinação com as diferentes doses de nitrogênio utilizadas nos quatro ambientes (experimentos).

Tabela 27. Resultado das análises individuais nos quatro ambientes, teste de homogeneidade e análise conjunta da variância de dados de rendimento de grãos (kg/ha) dos cinco genótipos em combinação com doses de nitrogênio.

\begin{tabular}{|c|c|c|c|c|c|c|c|}
\hline Ambiente & \multicolumn{2}{|c|}{ QM(Bloco) } & QM(Trat) & QM(Res) & $\mathrm{F}$ & Média & $\mathrm{CV}(\%)$ \\
\hline 1 & \multicolumn{2}{|c|}{7374002,97} & 28013681,51 & 682432,35 & $41,05 * *$ & 8007,8 & 10,32 \\
\hline 2 & \multicolumn{2}{|c|}{1245135,88} & 19193831,35 & 864927,95 & $22,19 * *$ & 7097,2 & 13,10 \\
\hline 3 & \multicolumn{2}{|c|}{363994,53} & 11980529,15 & 942785,94 & $12,71 * *$ & 7114,2 & 13,65 \\
\hline 4 & \multicolumn{2}{|c|}{3635106,92} & 5274588,75 & 324443,14 & $16,26 * *$ & 5821,8 & 9,78 \\
\hline GL & \multicolumn{2}{|c|}{2} & 24 & 48 & - & - & - \\
\hline \multicolumn{8}{|c|}{ Relação maior(QMR)/menor(QMR)=2,91 } \\
\hline \multicolumn{2}{|c|}{ FV } & GL & SQ & \multicolumn{2}{|c|}{ QM } & \multicolumn{2}{|c|}{$\mathrm{F}$} \\
\hline Blocos & & 2 & 8531694,26 & \multicolumn{2}{|c|}{4265847,13} & \\
\hline \multicolumn{2}{|c|}{ Tratamentos $\left(\mathrm{G}_{\mathrm{d}}\right)$} & 24 & 1276375764,42 & \multicolumn{2}{|c|}{53182323,52} & \multicolumn{2}{|c|}{$69,37 * *$} \\
\hline \multicolumn{2}{|c|}{ Ambientes (A) } & 3 & 182058502,54 & \multicolumn{2}{|c|}{60686167,51} & \multicolumn{2}{|c|}{$79,15^{* *}$} \\
\hline \multicolumn{2}{|c|}{$\mathrm{G}_{\mathrm{d}} \times \mathrm{A}$} & 72 & 270727373,63 & \multicolumn{2}{|c|}{3760102,41} & \multicolumn{2}{|c|}{$4,90 * *$} \\
\hline \multicolumn{2}{|l|}{ Resíduo } & 198 & 151805076,77 & \multicolumn{2}{|c|}{766692,31} & & \\
\hline \multicolumn{2}{|l|}{ Total } & 299 & 1889498411,62 & & & & \\
\hline \multicolumn{2}{|l|}{ Média } & & 7010,10 & & & & \\
\hline \multicolumn{2}{|l|}{ CV $(\%)$} & & 12,49 & & & & \\
\hline
\end{tabular}

A expressão básica fenotípica $\left(F=G_{d}+A\right)$, como resultado da ação de variações ambientais sobre o valor genotípico, de um determinado conjunto de dados, simplesmente, torna-se insuficiente para expressar a variação de dados de diferentes ambientes, principalmente se detectado valor significativo para a interação $G_{d} A$ (Chaves, 2001).

Dessa maneira, a inclusão da interação $G_{d} A$ na expressão $\left(F=G_{d}+A+G_{d} A\right)$ se fez necessária para que o seu efeito seja detectado. Sendo assim, deve-se utilizar o modelo explicitado na equação (2). 
Para que o quadrado médio residual da análise conjunta da variância represente uma estimativa não tendenciosa da variância residual média, deve haver homogeneidade da soma dos quadrados médios residuais entre os experimentos. Tal homogeneidade pode ser verificada pela razão entre a maior e a menor soma de quadrados médios das análises individuais, que não deve ser superior ao valor 4 para que a análise conjunta não seja considerada restritiva (Pimentel Gomes, 1985).

Pela Tabela 27, pode-se verificar pelo Teste $\mathrm{F}$ que são significativas as diferenças entre ambientes, entre tratamentos (genótipos dentro de doses) e na interação entre os dois fatores $\left(G_{d} A\right)$.

A Tabela 28 apresenta os dados de rendimento de grãos $(\mathrm{kg} / \mathrm{ha})$ obtidos nos quatro quatros ambientes (experimentos), e as estimativas dos efeitos principais dos tratamentos (genótipos em combinação com as diferentes doses de nitrogênio) (última coluna da Tabela 28) e dos ambientes (última linha da Tabela 28).

Os valores das estimativas dos efeitos principais foram estimados pelas expressões (3) e (4).

Pode-se verificar valores relativos negativos da estimativa do efeito do ambiente no experimento 4 (diferença entre os rendimentos), o qual representa a época de semeadura comumente denominada por "safrinha". Os valores indicam que o decréscimo no rendimento médio dos genótipos pode ser devido, em primeira instância, ao fator climático (em função da época de semeadura). Para pelo menos dois genótipos, o fator doença (causada por $P$. maydis) pode ter contribuído para a redução do rendimento médio de grãos.

Para as estimativas dos efeitos genotípicos, constata-se que a maioria dos genótipos utilizados possuem um bom potencial de resposta à aplicação do fertilizante nitrogenado, acima da dose de $120 \mathrm{~kg} / \mathrm{ha}$. Porém, a referida dose de nitrogênio aplicada não se justifica em termos da relação custo-benefício, para os ambientes 3 e 4 (localidade 2)., conforme observado na Tabela 29, Na referida Tabela estão apresentadas as estimativas dos efeitos da interação para cada combinação de tratamentos com os ambientes, estimados pela expressão (5), tirando-se do valor observado $Y_{\text {tak }}$, as estimativas dos efeitos principais e a média geral $Y_{\text {... }}$. 
Valores positivos e elevados da interação indicam uma boa adaptação relativa do genótipo $\left(\mathrm{G}_{\mathrm{d}}\right)$ ao ambiente. Nesse sentido, pôde-se observar que os genótipos respondem muito bem à adubação nitrogenada associada às condições favoráveis dos ambientes $1 \mathrm{e}$ 2 (localidade 1), especialmente os genótipos superprecoce (C-909) e precoce (P-30F45) no ambiente 1. Para a localidade 2 (ambientes 3 e 4), os referidos genótipos foram inadequados, pela associação das condições impostas desfavoráveis.

Para os ambientes 3 e 4, não seria recomendada a utilização dos tipos de genótipos testados (híbrido simples), pelo fato de que a maior restrição à utilização de técnicas para obtenção de elevados rendimentos estaria condicionada ao material genético inadequado. Talvez outros materiais (híbridos duplos e/ou triplos) apresentem uma maior adaptabilidade às condições impostas pelo ambiente, pois mesmo os genótipos (C-333B, P-30K75 e CO-9560) considerados tolerantes às principais doenças do milho, não obtiveram desempenho satisfatório (em termos de rendimentos de grãos). 
Tabela 28. Rendimento médio ( $\mathrm{kg} / \mathrm{ha}$ ) e estimativa dos efeitos principais dos genótipos dentro de dose de nitrogênio dos quatro diferentes ambientes (experimentos 1, $2,3$ e 4$)$.

\begin{tabular}{|c|c|c|c|c|c|c|c|}
\hline \multirow{2}{*}{ Genótipo } & \multirow{2}{*}{$\begin{array}{c}\text { Dose } \\
(\mathrm{kg} / \mathrm{ha})\end{array}$} & \multicolumn{4}{|c|}{ Experimento } & \multirow{2}{*}{$\begin{array}{c}\text { Média } \\
\left(\ddot{Y}_{i .}\right)\end{array}$} & \multirow{2}{*}{$\begin{array}{c}\text { Efeito } \\
\text { Genotípico } \\
\left(\hat{g}_{i .}\right)\end{array}$} \\
\hline & & 1 & 2 & 3 & 4 & & \\
\hline \multirow{5}{*}{ P-30F45 } & 0 & 4352,64 & 2663,37 & 1835,29 & 3318,81 & 3042,53 & $-3967,57$ \\
\hline & 60 & 5942,95 & 4664,47 & 6859,93 & 4928,28 & 5598,91 & $-1411,19$ \\
\hline & 120 & 7650,63 & 6916,81 & 7710,02 & 5692,64 & 6992,52 & $-17,58$ \\
\hline & 180 & 9878,80 & 8759,01 & 8402,33 & 6019,18 & 8264,83 & 1254,73 \\
\hline & 240 & 12424,53 & 10726,36 & 8937,49 & 6010,96 & 9524,83 & 2514,73 \\
\hline \multirow{5}{*}{ C-333B } & 0 & 2694,42 & 3692,87 & 4783,38 & 4848,40 & 4004,77 & $-3005,33$ \\
\hline & 60 & 5043,96 & 6220,77 & 7282,03 & 5839,36 & 6096,53 & $-913,57$ \\
\hline & 120 & 8246,92 & 7419,42 & 8144,97 & 6643,29 & 7613,65 & 603,55 \\
\hline & 180 & 10777,56 & 9349,89 & 8605,70 & 6530,46 & 8815,90 & 1805,80 \\
\hline & 240 & 12291,95 & 10266,39 & 9540,83 & 6400,21 & 9624,84 & 2614,74 \\
\hline \multirow{5}{*}{ P-30K 75} & 0 & 4066,19 & 3601,81 & 4337,88 & 3909,15 & 3978,76 & $-3031,34$ \\
\hline & 60 & 6171,85 & 5414,98 & 6353,31 & 6473,84 & 6103,49 & $-906,61$ \\
\hline & 120 & 9326,21 & 8315,29 & 8148,48 & 7791,42 & 8395,35 & 1385,25 \\
\hline & 180 & 9826,36 & 9310,47 & 8654,73 & 6620,82 & 8603,10 & 1593,00 \\
\hline & 240 & 11679,68 & 10257,47 & 8450,74 & 7938,28 & 9581,54 & 2571,44 \\
\hline \multirow{5}{*}{ CO-9560 } & 0 & 3720,04 & 3428,27 & 4942,94 & 4432,25 & 4130,87 & $-2879,23$ \\
\hline & 60 & 6144,58 & 6163,11 & 7307,83 & 6084,43 & 6424,99 & $-585,11$ \\
\hline & 120 & 8775,25 & 7568,95 & 8770,38 & 7124,78 & 8059,84 & 1049,74 \\
\hline & 180 & 10401,06 & 9269,25 & 8754,04 & 6813,71 & 8809,51 & 1799,41 \\
\hline & 240 & 10241,71 & 9809,45 & 9672,47 & 7714,49 & 9359,53 & 2349,43 \\
\hline \multirow{5}{*}{ C-909 } & 0 & 3240,11 & 3228,40 & 3007,07 & 2687,98 & 3040,89 & $-3969,21$ \\
\hline & 60 & 6282,64 & 5325,77 & 6437,65 & 4692,73 & 5684,70 & $-1325,40$ \\
\hline & 120 & 8294,80 & 6870,83 & 7036,98 & 5605,19 & 6951,95 & $-58,15$ \\
\hline & 180 & 10530,20 & 8738,85 & 7325,33 & 5519,68 & 8028,52 & 1018,42 \\
\hline & 240 & 12191,09 & 9448,63 & 6552,10 & 5889,13 & 8520,24 & 1510,14 \\
\hline Média $\left(\ddot{Y}_{. j}\right)$ & & 8007,84 & 7097,24 & 7114,16 & 5821,18 & - & 7010,10 \\
\hline $\begin{array}{c}\text { Efeito } \\
\text { Ambiental }\end{array}$ & $\left(\hat{a}_{j .}\right)$ & 997,74 & 87,14 & 104,06 & $-1188,92$ & - & - \\
\hline
\end{tabular}


Tabela 29. Estimativas dos efeitos da interação combinada de genótipos e doses de nitrogênio ( $T \hat{a}_{t a}$ ) com os quatro ambientes relativas aos dados da Tabela 28 .

\begin{tabular}{|c|c|c|c|c|c|}
\hline \multirow{2}{*}{ Genótipo } & \multirow{2}{*}{$\begin{array}{c}\text { Dose } \\
(\mathrm{kg} / \mathrm{ha})\end{array}$} & \multicolumn{4}{|c|}{ Experimento } \\
\hline & & 1 & 2 & 3 & 4 \\
\hline \multirow{5}{*}{ P-30F45 } & 0 & 312,37 & $-466,30$ & $-1311,30$ & 1465,21 \\
\hline & 60 & $-653,70$ & $-1021,57$ & 1156,96 & 518,30 \\
\hline & 120 & $-339,64$ & $-162,85$ & 613,43 & $-110,96$ \\
\hline & 180 & 616,23 & 407,04 & 33,44 & $-1056,73$ \\
\hline & 240 & 1901,95 & 1114,39 & $-691,41$ & $-2324,96$ \\
\hline \multirow{5}{*}{ C-333B } & 0 & $-2308,09$ & $-399,04$ & 674,55 & 2032,56 \\
\hline & 60 & $-2050,31$ & 37,10 & 1081,44 & 931,75 \\
\hline & 120 & $-364,47$ & $-281,37$ & 427,26 & 218,56 \\
\hline & 180 & 963,91 & 446,85 & $-314,26$ & $-1096,52$ \\
\hline & 240 & 1669,37 & 554,41 & $-188,08$ & $-2035,71$ \\
\hline \multirow{5}{*}{ P-30K 75} & 0 & $-910,31$ & $-464,09$ & 255,06 & 1119,32 \\
\hline & 60 & $-929,38$ & $-775,66$ & 145,76 & 1559,27 \\
\hline & 120 & $-66,88$ & $-167,20$ & $-350,93$ & 584,99 \\
\hline & 180 & 225,52 & 620,23 & $-52,42$ & $-793,35$ \\
\hline & 240 & 1100,39 & 588,79 & $-1234,86$ & $-454,34$ \\
\hline \multirow{5}{*}{ CO-9560 } & 0 & $-1408,58$ & $-789,74$ & 708,01 & 1490,30 \\
\hline & 60 & $-1278,15$ & $-349,02$ & 778,79 & 848,36 \\
\hline & 120 & $-282,33$ & $-578,03$ & 606,48 & 253,86 \\
\hline & 180 & 593,80 & 372,60 & $-159,53$ & $-806,89$ \\
\hline & 240 & $-115,56$ & 362,78 & 208,88 & $-456,12$ \\
\hline \multirow{5}{*}{ C-909 } & 0 & $-798,52$ & 100,36 & $-137,88$ & 836,01 \\
\hline & 60 & $-399,80$ & $-446,07$ & 648,90 & 196,95 \\
\hline & 120 & 345,11 & $-168,26$ & $-19,03$ & $-157,84$ \\
\hline & 180 & 1503,95 & 623,19 & $-807,24$ & $-1319,92$ \\
\hline & 240 & 2673,11 & 841,25 & $-2072,19$ & $-1442,19$ \\
\hline
\end{tabular}




\section{CONCLUSÕES}

De acordo com os resultados obtidos, concluiu-se que: (i) o desempenho do genótipo é dependente da época de semeadura, sendo que a adubação nitrogenada propicia maior aumento no rendimento de grãos quando a condição ambiental não é limitante: (i.1.) para o material susceptível à doença (genótipo 1: P-30F45), quando são comparados os dois locais, o rendimento médio do local 2 (primeira e segunda épocas) foi $65 \%$ do obtido no local 1 (terceira e quarta épocas); (i.2.) para os materiais tolerantes à doença (genótipos 2: C-333B, 3: P-30K75, 4: CO-9560e 5: C-909), quando são comparados os dois locais, o rendimento médio do local 2 (primeira e segunda épocas) foi 75\% (variação de 60\% - C-909 - a 82\% - CO-9560) do obtido no local 1 (terceira e quarta épocas); (i.3) para condição ambiental menos limitante (ambiente 1: época $1 \mathrm{e}$ local 1), a adubação nitrogenada propiciou aumento de rendimento médio (para todos os genótipos) de $236 \%$ (variação de $175 \%$ a $356 \%$ ); (i.4) para condição ambiental mais limitante (ambiente 4: época 4 e local 2), a adubação nitrogenada propiciou aumento de rendimento médio (para todos os genótipos) de $82 \%$ (variação de 32 a 119\%); e (i.5) para o genótipo susceptível (P-30F45) sob altas doses de nitrogênio e em condições de safrinha (elevada incidência do patógeno), o rendimento médio foi de $48 \%$ quando comparada com a semeadura antecipada (ambiente 1: época 1 e local 1), e (ii) a severidade de P. maydis é dependente da época de semeadura, da dose de nitrogênio e do material genético. O estresse da planta provocado por elevadas temperaturas predispõe a cultura à incidência da doença com maior severidade: (ii.1) para o genótipo susceptível, nas semeaduras tardias (épocas 3 e 4), a área foliar lesionada (estimada pelo índice de severidade da doença assumindo relação quadrática) variou em função do incremento da dose aplicada de nitrogênio de 38\% (0 kg/ha) a 73\% (240 kg/ha), sendo que para os genótipos tolerantes foi de $0,5 \%(0 \mathrm{~kg} / \mathrm{ha})$ a $8 \%(240 \mathrm{~kg} / \mathrm{ha})$. 
ANEXOS 


\section{ANEXO A}

Tabela 30. Valores mensais de temperatura $\left({ }^{\circ} \mathrm{C}\right)$ do ar (média das máximas e das mínimas e média geral), umidade relativa (\%) do ar (média das máximas e das mínimas e média geral), radiação global média $\left(\mathrm{MJ} / \mathrm{m}^{2}\right.$.dia) e chuva (mm/mês), nos diferentes períodos dos quatro experimentos $(\mathrm{E})$.

\begin{tabular}{|c|c|c|c|c|c|c|c|c|c|c|}
\hline \multirow{2}{*}{ E } & \multirow{2}{*}{ Período } & \multicolumn{3}{|c|}{ Temperatura $\left({ }^{\circ} \mathrm{C}\right)$} & \multicolumn{3}{|c|}{ Umidade Relativa (\%) } & \multirow{2}{*}{$\begin{array}{l}\text { Rad.Global } \\
\mathrm{MJ} / \mathrm{m}^{2} \text {.dia }\end{array}$} & \multicolumn{2}{|c|}{ Precipitação } \\
\hline & & Máx. & Mín. & Média & Máx. & Mín. & Média & & $\mathrm{mm}$ & $\begin{array}{c}\text { Dias } \\
\text { de chuva }\end{array}$ \\
\hline \multirow[t]{5}{*}{1} & $11 /$ set-30/set & 28,40 & 15,93 & 21,53 & 99,05 & 50,18 & 79,44 & 17,97 & 38,70 & 7 \\
\hline & 1/out-31/out & 31,60 & 18,11 & 24,20 & 99,25 & 41,93 & 75,46 & 20,24 & 102,70 & 9 \\
\hline & 1/nov-30/nov & 29,36 & 17,71 & 22,63 & 99,56 & 53,78 & 85,02 & 19,85 & 228,50 & 17 \\
\hline & $1 / \mathrm{dez}-31 / \mathrm{dez}$ & 29,35 & 18,94 & 23,24 & 99,91 & 60,71 & 88,52 & 19,15 & 187,50 & 18 \\
\hline & 1/jan-14/jan & 31,19 & 18,91 & 24,07 & 99,91 & 49,28 & 82,49 & 22,82 & 39,70 & 6 \\
\hline \multirow[t]{5}{*}{2} & 29/nov-30/nov & 29,68 & 18,93 & 23,23 & 100,00 & 59,17 & 89,70 & 21,03 & 38,70 & 2 \\
\hline & $1 / \mathrm{dez}-31 / \mathrm{dez}$ & 29,35 & 18,94 & 23,24 & 99,91 & 60,71 & 88,52 & 19,15 & 187,50 & 18 \\
\hline & 1/jan-31/jan & 31,11 & 19,56 & 24,37 & 99,83 & 52,43 & 84,35 & 22,04 & 214,00 & 18 \\
\hline & $1 / \mathrm{fev}-28 / \mathrm{fev}$ & 31,05 & 20,34 & 24,40 & 99,85 & 57,99 & 88,77 & 19,28 & 87,20 & 17 \\
\hline & $1 / \operatorname{mar}-31 / \mathrm{mar}$ & 30,75 & 19,34 & 24,13 & 100,00 & 55,10 & 86,82 & 18,93 & 160,80 & 14 \\
\hline \multirow[t]{5}{*}{3} & 27/dez-31/dez & - & - & - & - & - & - & - & - & - \\
\hline & 1/jan-31/jan & - & - & - & - & - & - & - & - & - \\
\hline & $1 / \mathrm{fev}-28 / \mathrm{fev}$ & - & - & - & - & - & - & - & - & - \\
\hline & $1 /$ mar-31/mar & - & - & - & - & - & - & - & - & - \\
\hline & 1/abr-21/abr & 29,82 & 16,38 & 22,43 & 100,00 & 55,29 & 88,52 & 18,57 & - & - \\
\hline \multirow[t]{5}{*}{4} & $22 / \mathrm{fev}-28 / \mathrm{fev}$ & - & - & - & - & - & - & - & - & - \\
\hline & $1 / \mathrm{mar}-31 / \mathrm{mar}$ & - & - & - & - & - & - & - & - & - \\
\hline & 1/abr-30/abr & 30,04 & 16,51 & 22,47 & 100,00 & 53,46 & 88,61 & 17,54 & - & - \\
\hline & 1/mai-31/mai & 24,69 & 12,28 & 17,65 & 100,00 & 63,58 & 93,18 & 12,30 & - & - \\
\hline & $1 /$ jun-18/jun & 26,41 & 13,05 & 18,58 & 100,00 & 58,99 & 93,17 & 12,27 & - & - \\
\hline
\end{tabular}




\section{ANEXO B}

Tabela 31. Análise de variância referente aos parâmetros: índice de área foliar (IAF, $\mathrm{m}^{2} / \mathrm{m}^{2}$ ) no florescimento; massa de 1000 grãos $\left(\mathrm{M}_{1000}, \mathrm{~g}\right)$; leitura do clorofilômetro (leitura SPAD, Lc) no estádio fenológico 8; rendimento de grãos $(\mathrm{R}, \mathrm{kg} / \mathrm{ha})$ e índice de severidade (IS) avaliado entre os estágios fenológicos 8 e 9.

\begin{tabular}{|c|c|c|c|c|c|c|c|c|c|c|c|c|}
\hline \multirow{2}{*}{ Experimento } & \multirow{2}{*}{$\mathrm{FV}^{1}$} & \multirow{2}{*}{$\mathrm{GL}^{2}$} & \multicolumn{2}{|c|}{ IAF } & \multicolumn{2}{|c|}{$\mathrm{M}_{1000}$} & \multicolumn{2}{|c|}{$\mathrm{Lc}$} & \multicolumn{2}{|c|}{$\mathrm{R}$} & \multicolumn{2}{|c|}{ IS } \\
\hline & & & $\mathrm{F}$ & Prob $^{3}$ & $\mathrm{~F}$ & Prob & $\mathrm{F}$ & Prob & $\mathrm{F}$ & Prob & $\mathrm{F}$ & Prob \\
\hline \multirow{4}{*}{1} & Bloco & 2 & 0,28 & 0,76 & 7,27 & $<0,01$ & 11,39 & $<0,01$ & 10,81 & $<0,01$ & 2,37 & 0,10 \\
\hline & Genótipos & 4 & 4,96 & $<0,01$ & 47,78 & $<0,01$ & 0,21 & 0,93 & 0,64 & 0,64 & 69,12 & $<0,01$ \\
\hline & Doses & 4 & 112,30 & $<0,01$ & 123,92 & $<0,01$ & 151,21 & $<0,01$ & 237,23 & $<0,01$ & 1,88 & 0,13 \\
\hline & $G \times D$ & 16 & 1,10 & 0,38 & 1,39 & 0,19 & 1,31 & 0,23 & 2,11 & 0,02 & 0,77 & 0,71 \\
\hline \multirow{4}{*}{2} & Bloco & 2 & 0,61 & 0,55 & 0,88 & 0,42 & 0,05 & 0,95 & 1,44 & 0,25 & 0,13 & 0,88 \\
\hline & Genótipos & 4 & 12,17 & $<0,01$ & 30,60 & $<0,01$ & 1,40 & 0,25 & 1,96 & 0,12 & 51,33 & $<0,01$ \\
\hline & Doses & 4 & 72,45 & $<0,01$ & 35,08 & $<0,01$ & 107,82 & $<0,01$ & 128,76 & $<0,01$ & 2,53 & 0,05 \\
\hline & $G \times D$ & 16 & 0,42 & 0,97 & 2,28 & 0,01 & 0,67 & 0,81 & 0,61 & 0,86 & 1,26 & 0,26 \\
\hline \multirow{4}{*}{3} & Bloco & 2 & 1,40 & 0,26 & 0,52 & 0,60 & 0,25 & 0,78 & 0,39 & 0,68 & 4,26 & 0,02 \\
\hline & Genótipos & 4 & 1,91 & 0,12 & 3,75 & 0,01 & 13,88 & $<0,01$ & 8,50 & $<0,01$ & 302,98 & $<0,01$ \\
\hline & Doses & 4 & 77,28 & $<0,01$ & 1,97 & 0,11 & 9,30 & 0,00 & 62,53 & $<0,01$ & 7,11 & $<0,01$ \\
\hline & $G \times D$ & 16 & 1,16 & 0,33 & 3,74 & $<0,01$ & 0,41 & 0,97 & 1,30 & 0,23 & 1,04 & 0,43 \\
\hline \multirow{4}{*}{4} & Bloco & 2 & 2,30 & 0,11 & 7,37 & $<0,01$ & 8,36 & $<0,01$ & 11,20 & $<0,01$ & 0,29 & 0,75 \\
\hline & Genótipos & 4 & 2,35 & 0,07 & 129,36 & $<0,01$ & 28,40 & $<0,01$ & 25,85 & $<0,01$ & 481,70 & $<0,01$ \\
\hline & Doses & 4 & 124,85 & $<0,01$ & 14,30 & $<0,01$ & 41,70 & $<0,01$ & 65,97 & $<0,01$ & 7,73 & $<0,01$ \\
\hline & $G \times D$ & 16 & 2,40 & 0,01 & 1,57 & 0,12 & 0,75 & 0,73 & 1,43 & 0,17 & 2,28 & 0,01 \\
\hline
\end{tabular}

1FV: Fonte de variação.

2 GL: Graus de liberdade.

3 Prob: Probabilidade a nível de 5\%. 
Tabela 32. Estimativas dos coeficientes da regressão polinomial: intercepto (a), linear (b) e quadrática (c) para os diferentes genótipos (efeito de doses) para os parâmetros rendimento $(\mathrm{R}, \mathrm{kg} / \mathrm{ha})$, massa de 1000 grãos $\left(\mathrm{M}_{1000}, \mathrm{~g}\right)$, leitura do clorofilômetro (leitura $\mathrm{SPAD}, \mathrm{Lc})$, índice de área foliar (IAF, $\mathrm{m}^{2} / \mathrm{m}^{2}$ ) no florescimento e índice de severidade (IS) à $P$. maydis. Experimento 1.

\begin{tabular}{|c|c|c|c|c|c|c|c|c|c|c|c|c|c|c|c|c|}
\hline \multirow{2}{*}{$\mathrm{P}^{1}$} & \multirow{2}{*}{$\mathrm{GL}^{2}$} & \multicolumn{3}{|c|}{$\mathrm{R}$} & \multicolumn{3}{|c|}{$\mathrm{M}_{1000}$} & \multicolumn{3}{|c|}{$\mathrm{Lc}$} & \multicolumn{3}{|c|}{ IAF } & \multicolumn{3}{|c|}{ IS } \\
\hline & & $\mathrm{Est}^{3}$ & $\mathrm{~s}^{*}$ & $\mathrm{Pr}^{4}$ & Est. & $\mathrm{s}$ & $\mathrm{Pr}$ & Est. & $\mathrm{S}$ & $\mathrm{Pr}$ & Est. & $\mathrm{S}$ & $\operatorname{Pr}$ & Est. & $\mathrm{S}$ & $\operatorname{Pr}$ \\
\hline a-g1 & 30 & 4381,31 & 453,09 & $<0,01$ & 311,03 & 8,15 & $<0,01$ & 18,58 & 2,79 & $<0,01$ & 2,61 & 0,32 & $<0,01$ & 2,20 & 0,14 & $<0,01$ \\
\hline a-g2 & 30 & 2490,56 & 453,09 & $<0,01$ & 278,96 & 8,15 & $<0,01$ & 20,54 & 2,79 & $<0,01$ & 3,03 & 0,32 & $<0,01$ & 1,00 & 0,14 & $<0,01$ \\
\hline$a-g 3$ & 30 & 3986,49 & 453,09 & $<0,01$ & 261,96 & 8,15 & $<0,01$ & 17,11 & 2,79 & $<0,01$ & 2,52 & 0,32 & $<0,01$ & 2,08 & 0,14 & $<0,01$ \\
\hline$a-g 4$ & 30 & 3514,71 & 453,09 & $<0,01$ & 254,90 & 8,15 & $<0,01$ & 20,18 & 2,79 & $<0,01$ & 2,17 & 0,32 & $<0,01$ & 1,29 & 0,14 & $<0,01$ \\
\hline a-g5 & 30 & 3315,03 & 453,09 & $<0,01$ & 253,63 & 8,15 & $<0,01$ & 19,75 & 2,79 & $<0,01$ & 1,96 & 0,32 & $<0,01$ & 1,55 & 0,14 & $<0,01$ \\
\hline b-g1 & 30 & 21,89 & 8,95 & 0,02 & 0,07 & 0,16 & 0,68 & 0,06 & 0,06 & 0,28 & 0,03 & 0,01 & $<0,01$ & 0,0 & 0,0 & 0,52 \\
\hline b-g2 & 30 & 52,70 & 8,95 & $<0,01$ & $-0,01$ & 0,16 & 0,96 & 0,09 & 0,06 & 0,13 & 0,02 & 0,01 & $<0,01$ & 0,0 & 0,0 & $>0,99$ \\
\hline b-g3 & 30 & 46,51 & 8,95 & $<0,01$ & 0,48 & 0,16 & 0,01 & 0,11 & 0,06 & 0,06 & 0,03 & 0,01 & $<0,01$ & 0,0 & 0,0 & 0,41 \\
\hline b-g4 & 30 & 58,23 & 8,95 & $<0,01$ & 0,39 & 0,16 & 0,02 & 0,11 & 0,06 & 0,06 & 0,04 & 0,01 & $<0,01$ & 0,0 & 0,0 & 0,37 \\
\hline b-g5 & 30 & 49,01 & 8,95 & $<0,01$ & 0,23 & 0,16 & 0,17 & 0,05 & 0,06 & 0,33 & 0,04 & 0,01 & $<0,01$ & $-0,01$ & 0,0 & 0,04 \\
\hline$c-g 1$ & 30 & 0,05 & 0,04 & 0,19 & 0,0 & 0,0 & 0,02 & 0,01 & 0,0 & 0,15 & 0,0 & 0,0 & 0,01 & 0,0 & 0,0 & 0,22 \\
\hline$c-g 2$ & 30 & $-0,05$ & 0,04 & 0,20 & 0,0 & 0,0 & 0,03 & 0,01 & 0,0 & 0,61 & 0,0 & 0,0 & 0,06 & 0,0 & 0,0 & $>0,99$ \\
\hline$c-g 3$ & 30 & $-0,06$ & 0,04 & 0,09 & 0,0 & 0,0 & 0,54 & 0,01 & 0,0 & 0,64 & 0,0 & 0,0 & $<0,01$ & 0,0 & 0,0 & 0,36 \\
\hline$c-g 4$ & 30 & $-0,12$ & 0,04 & $<0,01$ & 0,0 & 0,0 & 0,96 & 0,01 & 0,0 & 0,98 & 0,0 & 0,0 & $<0,01$ & 0,0 & 0,0 & 0,51 \\
\hline$c-g 5$ & 30 & $-0,05$ & 0,04 & 0,17 & 0,0 & 0,0 & 0,28 & 0,01 & 0,0 & 0,18 & 0,0 & 0,0 & $<0,01$ & 0,0 & 0,0 & 0,13 \\
\hline
\end{tabular}

1 P: Parâmetro do coeficiente do modelo.

2 GL: Graus de libaerdade

3 Est: Estimativa dos coeficientes (a: intercepto; b: linear; c: quadrático).

4 Pr: Probabilidade a nível de 5\%.

* Desvio padrão. 
Tabela 33. Estimativas dos coeficientes da regressão polinomial: intercepto (a), linear (b) e quadrática (c) para comparação entre os diferentes genótipos dos parâmetros rendimento $(\mathrm{R}, \mathrm{kg} / \mathrm{ha})$, massa de 1000 grãos $\left(\mathrm{M}_{1000}, \mathrm{~g}\right)$, leitura do clorofilômetro (leitura SPAD, Lc), índice de área foliar (IAF, $\mathrm{m}^{2} / \mathrm{m}^{2}$ ) no florescimento e índice de severidade (IS) à P. maydis. Experimento 1.

\begin{tabular}{|c|c|c|c|c|c|c|c|c|c|c|c|c|c|c|c|c|}
\hline \multirow{2}{*}{$\mathrm{P}^{1}$} & \multirow{2}{*}{$\mathrm{GL}^{2}$} & \multicolumn{3}{|c|}{$\mathrm{R}$} & \multicolumn{3}{|c|}{$\mathrm{M}_{1000}$} & \multicolumn{3}{|c|}{$\mathrm{Lc}$} & \multicolumn{3}{|c|}{ IAF } & \multicolumn{3}{|c|}{ IS } \\
\hline & & $\mathrm{Est}^{3}$ & $\mathrm{~s}^{*}$ & $\operatorname{Pr}^{4}$ & Est. & $\mathrm{S}$ & $\operatorname{Pr}$ & Est. & $\mathrm{S}$ & $\operatorname{Pr}$ & Est. & $\mathrm{S}$ & $\operatorname{Pr}$ & Est. & $\mathrm{s}$ & $\operatorname{Pr}$ \\
\hline ag1-ag2 & 30 & 1890,75 & 640,77 & 0,01 & 32,07 & 11,52 & 0,01 & $-1,96$ & 3,95 & 0,62 & $-0,42$ & 0,45 & 0,36 & 1,20 & 0,20 & $<0,01$ \\
\hline ag1-ag3 & 30 & 394,82 & 640,77 & 0,54 & 49,07 & 11,52 & $<0,01$ & 1,47 & 3,95 & 0,71 & 0,09 & 0,45 & 0,84 & 0,12 & 0,20 & 0,56 \\
\hline ag1-ag4 & 30 & 866,60 & 640,77 & 0,19 & 56,12 & 11,52 & $<0,01$ & $-1,60$ & 3,95 & 0,69 & 0,43 & 0,45 & 0,34 & 0,91 & 0,20 & $<0,01$ \\
\hline ag1-ag5 & 30 & 1066,28 & 640,77 & 0,11 & 57,39 & 11,52 & $<0,01$ & $-1,17$ & 3,95 & 0,77 & 0,65 & 0,45 & 0,16 & 0,64 & 0,20 & $<0,01$ \\
\hline ag2-ag3 & 30 & $-1495,93$ & 640,77 & 0,03 & 17,00 & 11,52 & 0,15 & 3,43 & 3,95 & 0,39 & 0,51 & 0,45 & 0,26 & $-1,08$ & 0,20 & $<0,01$ \\
\hline ag2-ag4 & 30 & $-1024,15$ & 640,77 & 0,12 & 24,06 & 11,52 & 0,05 & 0,37 & 3,95 & 0,93 & 0,86 & 0,45 & 0,07 & $-0,29$ & 0,20 & 0,16 \\
\hline ag2-ag5 & 30 & $-824,46$ & 640,77 & 0,21 & 25,33 & 11,52 & 0,04 & 0,79 & 3,95 & 0,84 & 1,07 & 0,45 & 0,02 & $-0,55$ & 0,20 & 0,01 \\
\hline ag3-ag4 & 30 & 471,79 & 640,77 & 0,47 & 7,05 & 11,52 & 0,54 & $-3,06$ & 3,95 & 0,44 & 0,34 & 0,45 & 0,46 & 0,79 & 0,20 & $<0,01$ \\
\hline ag3-ag5 & 30 & 671,47 & 640,77 & 0,30 & 8,32 & 11,52 & 0,48 & $-2,64$ & 3,95 & 0,51 & 0,56 & 0,45 & 0,23 & 0,53 & 0,20 & 0,01 \\
\hline ag4-ag5 & 30 & 199,68 & 640,77 & 0,76 & 1,27 & 11,52 & 0,91 & 0,43 & 3,95 & 0,91 & 0,22 & 0,45 & 0,63 & $-0,26$ & 0,20 & 0,20 \\
\hline bg1-bg2 & 30 & $-30,81$ & 12,65 & 0,02 & 0,07 & 0,23 & 0,74 & $-0,03$ & 0,08 & 0,74 & 0,0 & 0,01 & 0,61 & 0,0 & 0,0 & 0,65 \\
\hline bg1-bg3 & 30 & $-24,62$ & 12,65 & 0,06 & $-0,41$ & 0,23 & 0,08 & $-0,05$ & 0,08 & 0,55 & 0,0 & 0,01 & 0,67 & 0,0 & 0,0 & 0,90 \\
\hline bg1-bg4 & 30 & $-36,34$ & 12,65 & 0,01 & $-0,32$ & 0,23 & 0,17 & $-0,05$ & 0,08 & 0,55 & $-0,01$ & 0,01 & 0,38 & 0,0 & 0,0 & 0,28 \\
\hline bg1-bg5 & 30 & $-27,12$ & 12,65 & 0,04 & $-0,16$ & 0,23 & 0,49 & 0,01 & 0,08 & 0,94 & $-0,01$ & 0,01 & 0,42 & 0,01 & 0,0 & 0,06 \\
\hline bg2-bg3 & 30 & 6,19 & 12,65 & 0,63 & $-0,48$ & 0,23 & 0,04 & $-0,02$ & 0,08 & 0,79 & $-0,01$ & 0,01 & 0,36 & 0,0 & 0,0 & 0,56 \\
\hline bg2-bg4 & 30 & $-5,52$ & 12,65 & 0,67 & $-0,39$ & 0,23 & 0,09 & $-0,02$ & 0,08 & 0,78 & $-0,01$ & 0,01 & 0,17 & 0,0 & 0,0 & 0,52 \\
\hline bg2-bg5 & 30 & 3,69 & 12,65 & 0,77 & $-0,24$ & 0,23 & 0,31 & 0,03 & 0,08 & 0,69 & $-0,01$ & 0,01 & 0,19 & 0,01 & 0,0 & 0,14 \\
\hline bg3-bg4 & 30 & $-11,72$ & 12,65 & 0,36 & 0,09 & 0,23 & 0,69 & 0,00 & 0,08 & 0,99 & 0,00 & 0,01 & 0,65 & 0,00 & 0,0 & 0,23 \\
\hline bg3-bg5 & 30 & $-2,50$ & 12,65 & 0,84 & 0,25 & 0,23 & 0,28 & 0,05 & 0,08 & 0,51 & 0,00 & 0,01 & 0,70 & 0,01 & 0,0 & 0,04 \\
\hline bg4-bg5 & 30 & 9,22 & 12,65 & 0,47 & 0,16 & 0,23 & 0,49 & 0,05 & 0,08 & 0,50 & 0,00 & 0,01 & 0,95 & 0,0 & 0,0 & 0,39 \\
\hline $\operatorname{cg} 1-\operatorname{cg} 2$ & 30 & 0,09 & 0,05 & 0,07 & 0,0 & 0,00 & 0,83 & 0,00 & 0,00 & 0,50 & 0,00 & 0,00 & 0,45 & 0,0 & 0,0 & 0,38 \\
\hline $\operatorname{cg} 1-\operatorname{cg} 3$ & 30 & 0,11 & 0,05 & 0,04 & 0,0 & 0,00 & 0,03 & 0,00 & 0,00 & 0,48 & 0,00 & 0,00 & 0,72 & 0,0 & 0,0 & 0,81 \\
\hline $\operatorname{cg} 1-\operatorname{cg} 4$ & 30 & 0,17 & 0,05 & $<0,01$ & 0,0 & 0,00 & 0,08 & 0,00 & 0,00 & 0,31 & 0,00 & 0,00 & 0,58 & 0,0 & 0,0 & 0,18 \\
\hline $\operatorname{cg} 1-\operatorname{cg} 5$ & 30 & 0,10 & 0,05 & 0,06 & 0,0 & 0,00 & 0,32 & 0,00 & 0,00 & 0,93 & 0,00 & 0,00 & 0,54 & 0,0 & 0,0 & 0,06 \\
\hline $\operatorname{cg} 2-\operatorname{cg} 3$ & 30 & 0,02 & 0,05 & 0,75 & 0,0 & 0,00 & 0,05 & 0,00 & 0,00 & 0,97 & 0,00 & 0,00 & 0,26 & 0,0 & 0,0 & 0,52 \\
\hline $\operatorname{cg} 2-\operatorname{cg} 4$ & 30 & 0,08 & 0,05 & 0,14 & 0,0 & 0,00 & 0,12 & 0,00 & 0,00 & 0,73 & 0,00 & 0,00 & 0,19 & 0,0 & 0,0 & 0,64 \\
\hline $\operatorname{cg} 2-\operatorname{cg} 5$ & 30 & 0,00 & 0,05 & 0,94 & 0,0 & 0,00 & 0,43 & 0,00 & 0,00 & 0,55 & 0,00 & 0,00 & 0,17 & 0,0 & 0,0 & 0,28 \\
\hline $\operatorname{cg} 3-\operatorname{cg} 4$ & 30 & 0,06 & 0,05 & 0,25 & 0,0 & 0,00 & 0,69 & 0,00 & 0,00 & 0,75 & 0,00 & 0,00 & 0,84 & 0,0 & 0,0 & 0,27 \\
\hline $\operatorname{cg} 3-\operatorname{cg} 5$ & 30 & $-0,01$ & 0,05 & 0,81 & 0,0 & 0,00 & 0,23 & 0,00 & 0,00 & 0,53 & 0,00 & 0,00 & 0,80 & 0,0 & 0,0 & 0,09 \\
\hline $\operatorname{cg} 4-\operatorname{cg} 5$ & 30 & $-0,07$ & 0,05 & 0,16 & 0,0 & 0,00 & 0,42 & 0,00 & 0,00 & 0,35 & 0,00 & 0,00 & 0,96 & 0,0 & 0,0 & 0,53 \\
\hline
\end{tabular}


Tabela 34. Estimativas dos coeficientes da regressão polinomial: intercepto (a), linear (b) e quadrática (c) para os diferentes genótipos (efeito de doses) para os parâmetros rendimento $(\mathrm{R}, \mathrm{kg} / \mathrm{ha})$, massa de 1000 grãos $\left(\mathrm{M}_{1000}, \mathrm{~g}\right)$, leitura do clorofilômetro (leitura $\mathrm{SPAD}, \mathrm{Lc})$, índice de área foliar (IAF, $\mathrm{m}^{2} / \mathrm{m}^{2}$ ) no florescimento e índice de severidade (IS) à P. maydis. Experimento 2.

\begin{tabular}{|c|c|c|c|c|c|c|c|c|c|c|c|c|c|c|c|c|}
\hline \multirow{2}{*}{$\mathrm{P}^{1}$} & \multirow{2}{*}{$\mathrm{GL}^{2}$} & \multicolumn{3}{|c|}{$\mathrm{R}$} & \multicolumn{3}{|c|}{$\mathrm{M}_{1000}$} & \multicolumn{3}{|c|}{$\mathrm{Lc}$} & \multicolumn{3}{|c|}{ IAF } & \multicolumn{3}{|c|}{ IS } \\
\hline & & $\mathrm{Est}^{3}$ & $\mathrm{~s}^{*}$ & $\operatorname{Pr}^{4}$ & Est. & $\mathrm{S}$ & $\operatorname{Pr}$ & Est. & $\mathrm{S}$ & $\mathrm{Pr}$ & Est. & $\mathrm{s}$ & $\mathrm{Pr}$ & Est. & $\mathrm{S}$ & $\operatorname{Pr}$ \\
\hline a-g1 & 30 & 2633,66 & 497,71 & $<0,01$ & 254,47 & 7,42 & $<0,01$ & 20,97 & 2,32 & $<0,01$ & 2,30 & 0,27 & $<0,01$ & 2,55 & 0,19 & $<0,01$ \\
\hline a-g2 & 30 & 3778,78 & 497,71 & $<0,01$ & 275,13 & 7,42 & $<0,01$ & 26,78 & 2,32 & $<0,01$ & 3,64 & 0,27 & $<0,01$ & 1,08 & 0,19 & $<0,01$ \\
\hline a-g3 & 30 & 3419,00 & 497,71 & $<0,01$ & 273,29 & 7,42 & $<0,01$ & 22,14 & 2,32 & $<0,01$ & 2,42 & 0,27 & $<0,01$ & 2,05 & 0,19 & $<0,01$ \\
\hline$a-g 4$ & 30 & 3489,13 & 497,71 & $<0,01$ & 247,29 & 7,42 & $<0,01$ & 23,81 & 2,32 & $<0,01$ & 2,43 & 0,27 & $<0,01$ & 1,25 & 0,19 & $<0,01$ \\
\hline a-g5 & 30 & 3201,46 & 497,71 & $<0,01$ & 233,48 & 7,42 & $<0,01$ & 26,89 & 2,32 & $<0,01$ & 2,00 & 0,27 & $<0,01$ & 1,82 & 0,19 & $<0,01$ \\
\hline b-g1 & 30 & 35,98 & 9,83 & $<0,01$ & 0,58 & 0,15 & $<0,01$ & 0,14 & 0,05 & 0,01 & 0,03 & 0,01 & $<0,01$ & 0,01 & 0,00 & 0,01 \\
\hline b-g2 & 30 & 38,99 & 9,83 & $<0,01$ & $-0,01$ & 0,15 & 0,95 & 0,07 & 0,05 & 0,13 & 0,01 & 0,01 & 0,02 & 0,00 & 0,00 & 0,67 \\
\hline b-g3 & 30 & 46,00 & 9,83 & $<0,01$ & 0,03 & 0,15 & 0,82 & 0,09 & 0,05 & 0,06 & 0,03 & 0,01 & $<0,01$ & 0,00 & 0,00 & 0,24 \\
\hline b-g4 & 30 & 45,95 & 9,83 & $<0,01$ & 0,14 & 0,15 & 0,34 & 0,11 & 0,05 & 0,02 & 0,02 & 0,01 & $<0,01$ & 0,00 & 0,00 & 0,49 \\
\hline b-g5 & 30 & 38,10 & 9,83 & $<0,01$ & 0,18 & 0,15 & 0,24 & 0,08 & 0,05 & 0,10 & 0,02 & 0,01 & $<0,01$ & 0,00 & 0,00 & 0,42 \\
\hline$c-g 1$ & 30 & $-0,01$ & 0,04 & 0,81 & 0,00 & 0,00 & 0,30 & 0,00 & 0,00 & 0,98 & 0,00 & 0,00 & 0,02 & 0,00 & 0,00 & 0,01 \\
\hline $\mathrm{c}-\mathrm{g} 2$ & 30 & $-0,05$ & 0,04 & 0,22 & 0,00 & 0,00 & 0,23 & 0,00 & 0,00 & 0,60 & 0,00 & 0,00 & 0,71 & 0,00 & 0,00 & 0,62 \\
\hline$c-g 3$ & 30 & $-0,07$ & 0,04 & 0,08 & 0,00 & 0,00 & 0,37 & 0,00 & 0,00 & 0,54 & 0,00 & 0,00 & 0,01 & 0,00 & 0,00 & 0,89 \\
\hline $\mathrm{c}-\mathrm{g} 4$ & 30 & $-0,08$ & 0,04 & 0,05 & 0,00 & 0,00 & 0,29 & 0,00 & 0,00 & 0,91 & 0,00 & 0,00 & 0,12 & 0,00 & 0,00 & 0,59 \\
\hline c-g5 & 30 & $-0,05$ & 0,04 & 0,22 & 0,00 & 0,00 & 0,83 & 0,00 & 0,00 & 0,55 & 0,00 & 0,00 & 0,09 & 0,00 & 0,00 & 0,86 \\
\hline
\end{tabular}

1 P: Parâmetro do coeficiente do modelo

2 GL: Graus de libaerdade

3 Est: Estimativa dos coeficientes (a: intercepto; b: linear; c: quadrático).

4 Pr: Probabilidade a nível de 5\%.

* Desvio padrão. 
Tabela 35. Estimativas dos coeficientes da regressão polinomial: intercepto (a), linear (b) e quadrática (c) para comparação entre os diferentes genótipos dos parâmetros rendimento $(\mathrm{R}, \mathrm{kg} / \mathrm{ha})$, massa de 1000 grãos $\left(\mathrm{M}_{1000}, \mathrm{~g}\right)$, leitura do clorofilômetro (leitura $\mathrm{SPAD}, \mathrm{Lc})$, índice de área foliar (IAF, $\mathrm{m}^{2} / \mathrm{m}^{2}$ ) no florescimento e índice de severidade (IS) à P. maydis. Experimento 2.

\begin{tabular}{|c|c|c|c|c|c|c|c|c|c|c|c|c|c|c|c|c|}
\hline \multirow{2}{*}{$\mathrm{P}^{1}$} & \multirow{2}{*}{$\mathrm{GL}^{2}$} & \multicolumn{3}{|c|}{$\mathrm{R}$} & \multicolumn{3}{|c|}{$\mathrm{M}_{1000}$} & \multicolumn{3}{|c|}{ Lc } & \multicolumn{3}{|c|}{ IAF } & \multicolumn{3}{|c|}{ IS } \\
\hline & & $\mathrm{Est}^{3}$ & $\mathrm{~s}^{*}$ & $\operatorname{Pr}^{4}$ & Est. & $\mathrm{S}$ & $\mathrm{Pr}$ & Est. & $\mathrm{S}$ & $\operatorname{Pr}$ & Est. & $\mathrm{S}$ & $\mathrm{Pr}$ & Est. & $\mathrm{s}$ & $\mathrm{Pr}$ \\
\hline ag1-ag2 & 30 & $-1145,12$ & 703,87 & 0,11 & $-20,66$ & 10,49 & 0,06 & $-5,81$ & 3,28 & 0,09 & $-1,34$ & 0,39 & $<0,01$ & 1,48 & 0,26 & $<0,01$ \\
\hline ag1-ag3 & 30 & $-785,34$ & 703,87 & 0,27 & $-18,82$ & 10,49 & 0,08 & $-1,17$ & 3,28 & 0,72 & $-0,12$ & 0,39 & 0,75 & 0,51 & 0,26 & 0,06 \\
\hline ag1-ag4 & 30 & $-855,47$ & 703,87 & 0,23 & 7,18 & 10,49 & 0,50 & $-2,84$ & 3,28 & 0,39 & $-0,13$ & 0,39 & 0,74 & 1,30 & 0,26 & $<0,01$ \\
\hline ag1-ag5 & 30 & $-567,81$ & 703,87 & 0,43 & 20,99 & 10,49 & 0,05 & $-5,91$ & 3,28 & 0,08 & 0,29 & 0,39 & 0,46 & 0,74 & 0,26 & 0,01 \\
\hline ag2-ag3 & 30 & 359,78 & 703,87 & 0,61 & 1,84 & 10,49 & 0,86 & 4,64 & 3,28 & 0,17 & 1,22 & 0,39 & $<0,01$ & $-0,97$ & 0,26 & $<0,01$ \\
\hline ag2-ag4 & 30 & 289,65 & 703,87 & 0,68 & 27,84 & 10,49 & 0,01 & 2,97 & 3,28 & 0,37 & 1,21 & 0,39 & $<0,01$ & $-0,17$ & 0,26 & 0,52 \\
\hline ag2-ag5 & 30 & 577,32 & 703,87 & 0,42 & 41,64 & 10,49 & $<0,01$ & $-0,11$ & 3,28 & 0,97 & 1,63 & 0,39 & $<0,01$ & $-0,74$ & 0,26 & 0,01 \\
\hline ag3-ag4 & 30 & $-70,13$ & 703,87 & 0,92 & 25,99 & 10,49 & 0,02 & $-1,67$ & 3,28 & 0,61 & $-0,01$ & 0,39 & 0,99 & 0,80 & 0,26 & 0,01 \\
\hline ag3-ag5 & 30 & 217,53 & 703,87 & 0,76 & 39,80 & 10,49 & $<0,01$ & $-4,75$ & 3,28 & 0,16 & 0,42 & 0,39 & 0,29 & 0,23 & 0,26 & 0,39 \\
\hline ag4-ag5 & 30 & 287,66 & 703,87 & 0,69 & 13,81 & 10,49 & 0,20 & $-3,07$ & 3,28 & 0,36 & 0,42 & 0,39 & 0,28 & $-0,57$ & 0,26 & 0,04 \\
\hline bg1-bg2 & 30 & $-3,01$ & 13,90 & 0,83 & 0,59 & 0,21 & 0,01 & 0,07 & 0,06 & 0,31 & 0,01 & 0,01 & 0,12 & 0,01 & 0,01 & 0,03 \\
\hline bg1-bg3 & 30 & $-10,02$ & 13,90 & 0,48 & 0,54 & 0,21 & 0,01 & 0,05 & 0,06 & 0,47 & 0,00 & 0,01 & 0,77 & 0,01 & 0,01 & 0,01 \\
\hline bg1-bg4 & 30 & $-9,97$ & 13,90 & 0,48 & 0,43 & 0,21 & 0,04 & 0,02 & 0,06 & 0,72 & 0,00 & 0,01 & 0,56 & 0,01 & 0,01 & 0,02 \\
\hline bg1-bg5 & 30 & $-2,12$ & 13,90 & 0,88 & 0,40 & 0,21 & 0,06 & 0,06 & 0,06 & 0,37 & 0,00 & 0,01 & 0,58 & 0,01 & 0,01 & 0,02 \\
\hline bg2-bg3 & 30 & $-7,01$ & 13,90 & 0,62 & $-0,04$ & 0,21 & 0,83 & $-0,02$ & 0,06 & 0,77 & $-0,01$ & 0,01 & 0,07 & 0,00 & 0,01 & 0,59 \\
\hline bg2-bg4 & 30 & $-6,96$ & 13,90 & 0,62 & $-0,15$ & 0,21 & 0,47 & $-0,04$ & 0,06 & 0,51 & $-0,01$ & 0,01 & 0,33 & 0,00 & 0,01 & 0,85 \\
\hline bg2-bg5 & 30 & 0,89 & 13,90 & 0,95 & $-0,19$ & 0,21 & 0,37 & $-0,01$ & 0,06 & 0,90 & $-0,01$ & 0,01 & 0,32 & 0,00 & 0,01 & 0,79 \\
\hline bg3-bg4 & 30 & 0,05 & 13,90 & 1,00 & $-0,11$ & 0,21 & 0,60 & $-0,02$ & 0,06 & 0,71 & 0,01 & 0,01 & 0,39 & 0,00 & 0,01 & 0,72 \\
\hline bg3-bg5 & 30 & 7,90 & 13,90 & 0,57 & $-0,14$ & 0,21 & 0,49 & 0,01 & 0,06 & 0,86 & 0,01 & 0,01 & 0,40 & 0,00 & 0,01 & 0,78 \\
\hline bg4-bg5 & 30 & 7,85 & 13,90 & 0,58 & $-0,03$ & 0,21 & 0,87 & 0,04 & 0,06 & 0,59 & 0,00 & 0,01 & 0,99 & 0,00 & 0,01 & 0,94 \\
\hline $\operatorname{cg} 1-\operatorname{cg} 2$ & 30 & 0,04 & 0,06 & 0,48 & 0,00 & 0,00 & 0,12 & 0,00 & 0,00 & 0,73 & 0,00 & 0,00 & 0,17 & 0,00 & 0,00 & 0,02 \\
\hline $\operatorname{cg} 1-\operatorname{cg} 3$ & 30 & 0,06 & 0,06 & 0,27 & 0,00 & 0,00 & 0,18 & 0,00 & 0,00 & 0,68 & 0,00 & 0,00 & 0,69 & 0,00 & 0,00 & 0,03 \\
\hline $\operatorname{cg} 1-\operatorname{cg} 4$ & 30 & 0,07 & 0,06 & 0,21 & 0,00 & 0,00 & 0,14 & 0,00 & 0,00 & 0,95 & 0,00 & 0,00 & 0,59 & 0,00 & 0,00 & 0,02 \\
\hline $\operatorname{cg} 1-\operatorname{cg} 5$ & 30 & 0,04 & 0,06 & 0,49 & 0,00 & 0,00 & 0,56 & 0,00 & 0,00 & 0,68 & 0,00 & 0,00 & 0,65 & 0,00 & 0,00 & 0,03 \\
\hline $\operatorname{cg} 2-\operatorname{cg} 3$ & 30 & 0,02 & 0,06 & 0,68 & 0,00 & 0,00 & 0,82 & 0,00 & 0,00 & 0,95 & 0,00 & 0,00 & 0,08 & 0,00 & 0,00 & 0,80 \\
\hline $\operatorname{cg} 2-\operatorname{cg} 4$ & 30 & 0,03 & 0,06 & 0,57 & 0,00 & 0,00 & 0,92 & 0,00 & 0,00 & 0,77 & 0,00 & 0,00 & 0,39 & 0,00 & 0,00 & 0,97 \\
\hline $\operatorname{cg} 2-\operatorname{cg} 5$ & 30 & 0,00 & 0,06 & 0,99 & 0,00 & 0,00 & 0,31 & 0,00 & 0,00 & 0,96 & 0,00 & 0,00 & 0,35 & 0,00 & 0,00 & 0,82 \\
\hline $\operatorname{cg} 3-\operatorname{cg} 4$ & 30 & 0,01 & 0,06 & 0,87 & 0,00 & 0,00 & 0,90 & 0,00 & 0,00 & 0,72 & 0,00 & 0,00 & 0,35 & 0,00 & 0,00 & 0,78 \\
\hline $\operatorname{cg} 3-\operatorname{cg} 5$ & 30 & $-0,02$ & 0,06 & 0,67 & 0,00 & 0,00 & 0,43 & 0,00 & 0,00 & 1,00 & 0,00 & 0,00 & 0,39 & 0,00 & 0,00 & 0,97 \\
\hline $\operatorname{cg} 4-\operatorname{cg} 5$ & 30 & $-0,03$ & 0,06 & 0,56 & 0,00 & 0,00 & 0,36 & 0,00 & 0,00 & 0,73 & 0,00 & 0,00 & 0,94 & 0,00 & 0,00 & 0,80 \\
\hline
\end{tabular}


Tabela 36. Estimativas dos coeficientes da regressão polinomial: intercepto (a), linear (b) e quadrática (c) para os diferentes genótipos (efeito de doses) para os parâmetros rendimento $(\mathrm{R}, \mathrm{kg} / \mathrm{ha})$, massa de 1000 grãos $\left(\mathrm{M}_{1000}, \mathrm{~g}\right)$, leitura do clorofilômetro (leitura $\mathrm{SPAD}, \mathrm{Lc})$, índice de área foliar (IAF, $\mathrm{m}^{2} / \mathrm{m}^{2}$ ) no florescimento e índice de severidade (IS) à $P$. maydis. Experimento 3.

\begin{tabular}{|c|c|c|c|c|c|c|c|c|c|c|c|c|c|c|c|c|}
\hline \multirow{2}{*}{$\mathrm{P}^{1}$} & \multirow{2}{*}{$\mathrm{GL}^{2}$} & \multicolumn{3}{|c|}{$\mathrm{R}$} & \multicolumn{3}{|c|}{$\mathrm{M}_{1000}$} & \multicolumn{3}{|c|}{$\mathrm{Lc}$} & \multicolumn{3}{|c|}{ IAF } & \multicolumn{3}{|c|}{ IS } \\
\hline & & $\mathrm{Est}^{3}$ & $\mathrm{~s}^{*}$ & $\mathrm{Pr}^{4}$ & Estim. & $\mathrm{S}$ & $\operatorname{Pr}$ & Estim. & $\mathrm{s}$ & $\operatorname{Pr}$ & Estim. & $\mathrm{s}$ & $\operatorname{Pr}$ & Estim. & $\mathrm{S}$ & $\operatorname{Pr}$ \\
\hline a-g1 & 30 & 2294,40 & 555,53 & $<0,01$ & 258,66 & 7,79 & $<0,01$ & 19,98 & 3,43 & $<0,01$ & 2,25 & 0,16 & $<0,01$ & 6,77 & 0,24 & 0,00 \\
\hline a-g2 & 30 & 4999,49 & 555,53 & $<0,01$ & 299,68 & 7,79 & $<0,01$ & 37,07 & 3,43 & $<0,01$ & 2,59 & 0,16 & $<0,01$ & 2,54 & 0,24 & 0,00 \\
\hline a-g3 & 30 & 4265,34 & 555,53 & $<0,01$ & 284,77 & 7,79 & $<0,01$ & 27,80 & 3,43 & $<0,01$ & 2,01 & 0,16 & $<0,01$ & 3,56 & 0,24 & 0,00 \\
\hline a-g4 & 30 & 5083,93 & 555,53 & $<0,01$ & 290,07 & 7,79 & $<0,01$ & 27,64 & 3,43 & $<0,01$ & 2,18 & 0,16 & $<0,01$ & 3,25 & 0,24 & 0,00 \\
\hline a-g5 & 30 & 3230,77 & 555,53 & $<0,01$ & 242,74 & 7,79 & $<0,01$ & 22,79 & 3,43 & $<0,01$ & 2,45 & 0,16 & $<0,01$ & 4,04 & 0,24 & 0,00 \\
\hline b-g1 & 30 & 69,75 & 10,97 & $<0,01$ & 0,66 & 0,15 & $<0,01$ & 0,01 & 0,07 & 0,86 & 0,02 & 0,00 & $<0,01$ & 0,01 & 0,00 & 0,01 \\
\hline b-g2 & 30 & 34,87 & 10,97 & $<0,01$ & 0,15 & 0,15 & 0,35 & 0,08 & 0,07 & 0,23 & 0,01 & 0,00 & $<0,01$ & 0,01 & 0,00 & 0,12 \\
\hline b-g3 & 30 & 44,82 & 10,97 & $<0,01$ & 0,11 & 0,15 & 0,49 & 0,03 & 0,07 & 0,71 & 0,02 & 0,00 & $<0,01$ & 0,01 & 0,00 & 0,11 \\
\hline b-g4 & 30 & 38,99 & 10,97 & $<0,01$ & 0,19 & 0,15 & 0,22 & 0,03 & 0,07 & 0,71 & 0,02 & 0,00 & $<0,01$ & 0,00 & 0,00 & 0,76 \\
\hline b-g5 & 30 & 54,81 & 10,97 & $<0,01$ & 0,31 & 0,15 & 0,05 & 0,10 & 0,07 & 0,15 & 0,01 & 0,00 & $<0,01$ & 0,01 & 0,00 & 0,14 \\
\hline c-g1 & 30 & $-0,18$ & 0,04 & $<0,01$ & 0,00 & 0,00 & $<0,01$ & 0,00 & 0,00 & 0,56 & 0,00 & 0,00 & $<0,01$ & 0,00 & 0,00 & 0,05 \\
\hline c-g2 & 30 & $-0,07$ & 0,04 & 0,12 & 0,00 & 0,00 & 0,63 & 0,00 & 0,00 & 0,53 & 0,00 & 0,00 & 0,02 & 0,00 & 0,00 & 0,29 \\
\hline$c-g 3$ & 30 & $-0,11$ & 0,04 & 0,01 & 0,00 & 0,00 & 0,85 & 0,00 & 0,00 & 0,59 & 0,00 & 0,00 & $<0,01$ & 0,00 & 0,00 & 0,08 \\
\hline c-g4 & 30 & $-0,09$ & 0,04 & 0,06 & 0,00 & 0,00 & 0,45 & 0,00 & 0,00 & 0,65 & 0,00 & 0,00 & $<0,01$ & 0,00 & 0,00 & 0,93 \\
\hline c-g5 & 30 & $-0,17$ & 0,04 & $<0,01$ & 0,00 & 0,00 & 0,20 & 0,00 & 0,00 & 0,67 & 0,00 & 0,00 & 0,01 & 0,00 & 0,00 & 0,28 \\
\hline
\end{tabular}

1 P: Parâmetro do coeficiente do modelo

2 GL: Graus de libaerdade

3 Est: Estimativa dos coeficientes (a: intercepto; b: linear; c: quadrático).

4 Pr: Probabilidade a nível de $5 \%$.

* Desvio padrão. 
Tabela 37. Estimativas dos coeficientes da regressão polinomial: intercepto (a), linear (b) e quadrática (c) para comparação entre os diferentes genótipos dos parâmetros rendimento $(\mathrm{R}, \mathrm{kg} / \mathrm{ha})$, massa de 1000 grãos $\left(\mathrm{M}_{1000}, \mathrm{~g}\right)$, leitura do clorofilômetro (leitura $\mathrm{SPAD}, \mathrm{Lc})$, índice de área foliar (IAF, $\mathrm{m}^{2} / \mathrm{m}^{2}$ ) no florescimento e índice de severidade (IS) à P. maydis. Experimento 3.

\begin{tabular}{|c|c|c|c|c|c|c|c|c|c|c|c|c|c|c|c|c|}
\hline \multirow{2}{*}{$\mathrm{P}^{1}$} & \multirow{2}{*}{$\mathrm{GL}^{2}$} & \multicolumn{3}{|c|}{$\mathrm{R}$} & \multicolumn{3}{|c|}{$\mathrm{M}_{1000}$} & \multicolumn{3}{|c|}{$\mathrm{Lc}$} & \multicolumn{3}{|c|}{ IAF } & \multicolumn{3}{|c|}{ IS } \\
\hline & & $\mathrm{Est}^{3}$ & $\mathrm{~S}^{*}$ & $\operatorname{Pr}^{4}$ & Estim. & $\mathrm{S}$ & $\operatorname{Pr}$ & Estim. & $\mathrm{S}$ & $\operatorname{Pr}$ & Estim. & $\mathrm{S}$ & $\operatorname{Pr}$ & Estim. & $\mathrm{s}$ & $\operatorname{Pr}$ \\
\hline ag1-ag2 & 30 & $-2705,09$ & 785,64 & $<0,01$ & $-41,02$ & 11,02 & $<0,01$ & $-17,09$ & 4,85 & $<0,01$ & $-0,34$ & 0,23 & 0,14 & 4,23 & 0,34 & $<0,01$ \\
\hline ag1-ag3 & 30 & $-1970,94$ & 785,64 & 0,02 & $-26,11$ & 11,02 & 0,02 & $-7,81$ & 4,85 & 0,12 & 0,24 & 0,23 & 0,30 & 3,20 & 0,34 & $<0,01$ \\
\hline ag1-ag4 & 30 & $-2789,53$ & 785,64 & $<0,01$ & $-31,40$ & 11,02 & 0,01 & $-7,65$ & 4,85 & 0,13 & 0,07 & 0,23 & 0,76 & 3,52 & 0,34 & $<0,01$ \\
\hline ag1-ag5 & 30 & $-936,37$ & 785,64 & 0,24 & 15,92 & 11,02 & 0,16 & $-2,81$ & 4,85 & 0,57 & $-0,21$ & 0,23 & 0,37 & 2,73 & 0,34 & $<0,01$ \\
\hline ag2-ag3 & 30 & 734,14 & 785,64 & 0,36 & 14,91 & 11,02 & 0,19 & 9,27 & 4,85 & 0,07 & 0,59 & 0,23 & 0,02 & $-1,02$ & 0,34 & 0,01 \\
\hline ag2-ag4 & 30 & $-84,44$ & 785,64 & 0,92 & 9,62 & 11,02 & 0,39 & 9,43 & 4,85 & 0,06 & 0,41 & 0,23 & 0,08 & $-0,71$ & 0,34 & 0,05 \\
\hline ag2-ag5 & 30 & 1768,72 & 785,64 & 0,03 & 56,95 & 11,02 & $<0,01$ & 14,28 & 4,85 & 0,01 & 0,14 & 0,23 & 0,56 & $-1,50$ & 0,34 & $<0,01$ \\
\hline ag3-ag4 & 30 & $-818,59$ & 785,64 & 0,31 & $-5,29$ & 11,02 & 0,63 & 0,16 & 4,85 & 0,97 & $-0,17$ & 0,23 & 0,45 & 0,31 & 0,34 & 0,37 \\
\hline ag3-ag5 & 30 & 1034,57 & 785,64 & 0,20 & 42,04 & 11,02 & $<0,01$ & 5,00 & 4,85 & 0,31 & $-0,45$ & 0,23 & 0,06 & $-0,47$ & 0,34 & 0,18 \\
\hline ag4-ag5 & 30 & 1853,16 & 785,64 & 0,03 & 47,33 & 11,02 & $<0,01$ & 4,84 & 4,85 & 0,33 & $-0,28$ & 0,23 & 0,23 & $-0,79$ & 0,34 & 0,03 \\
\hline bg1-bg2 & 30 & 34,88 & 15,51 & 0,03 & 0,51 & 0,22 & 0,03 & $-0,07$ & 0,10 & 0,46 & 0,00 & 0,00 & 0,37 & 0,01 & 0,01 & 0,43 \\
\hline bg1-bg3 & 30 & 24,93 & 15,51 & 0,12 & 0,55 & 0,22 & 0,02 & $-0,01$ & 0,10 & 0,89 & 0,00 & 0,00 & 0,31 & 0,01 & 0,01 & 0,46 \\
\hline bg1-bg4 & 30 & 30,76 & 15,51 & 0,06 & 0,47 & 0,22 & 0,04 & $-0,01$ & 0,10 & 0,89 & $-0,01$ & 0,00 & 0,24 & 0,01 & 0,01 & 0,10 \\
\hline bg1-bg5 & 30 & 14,94 & 15,51 & 0,34 & 0,35 & 0,22 & 0,12 & $-0,09$ & 0,10 & 0,36 & 0,00 & 0,00 & 0,46 & 0,01 & 0,01 & 0,39 \\
\hline bg2-bg3 & 30 & $-9,95$ & 15,51 & 0,53 & 0,04 & 0,22 & 0,86 & 0,06 & 0,10 & 0,55 & $-0,01$ & 0,00 & 0,06 & 0,00 & 0,01 & 0,96 \\
\hline bg2-bg4 & 30 & $-4,12$ & 15,51 & 0,79 & $-0,05$ & 0,22 & 0,83 & 0,06 & 0,10 & 0,55 & $-0,01$ & 0,00 & 0,04 & 0,01 & 0,01 & 0,37 \\
\hline bg2-bg5 & 30 & $-19,94$ & 15,51 & 0,21 & $-0,17$ & 0,22 & 0,45 & $-0,02$ & 0,10 & 0,87 & 0,00 & 0,00 & 0,87 & 0,00 & 0,01 & 0,95 \\
\hline bg3-bg4 & 30 & 5,83 & 15,51 & 0,71 & $-0,09$ & 0,22 & 0,69 & 0,00 & 0,10 & 1,00 & 0,00 & 0,00 & 0,86 & 0,01 & 0,01 & 0,35 \\
\hline bg3-bg5 & 30 & $-9,99$ & 15,51 & 0,52 & $-0,21$ & 0,22 & 0,35 & $-0,07$ & 0,10 & 0,44 & 0,01 & 0,00 & 0,09 & 0,00 & 0,01 & 0,91 \\
\hline bg4-bg5 & 30 & $-15,82$ & 15,51 & 0,32 & $-0,12$ & 0,22 & 0,59 & $-0,07$ & 0,10 & 0,44 & 0,01 & 0,00 & 0,06 & $-0,01$ & 0,01 & 0,41 \\
\hline $\operatorname{cg} 1-\operatorname{cg} 2$ & 30 & $-0,11$ & 0,06 & 0,08 & 0,00 & 0,00 & 0,06 & 0,00 & 0,00 & 0,39 & 0,00 & 0,00 & 0,46 & 0,00 & 0,00 & 0,48 \\
\hline $\operatorname{cg} 1-\operatorname{cg} 3$ & 30 & $-0,07$ & 0,06 & 0,28 & 0,00 & 0,00 & 0,04 & 0,00 & 0,00 & 0,97 & 0,00 & 0,00 & 0,43 & 0,00 & 0,00 & 0,84 \\
\hline $\operatorname{cg} 1-\operatorname{cg} 4$ & 30 & $-0,09$ & 0,06 & 0,14 & 0,00 & 0,00 & 0,09 & 0,00 & 0,00 & 0,92 & 0,00 & 0,00 & 0,35 & 0,00 & 0,00 & 0,17 \\
\hline $\operatorname{cg} 1-\operatorname{cg} 5$ & 30 & $-0,01$ & 0,06 & 0,89 & 0,00 & 0,00 & 0,19 & 0,00 & 0,00 & 0,47 & 0,00 & 0,00 & 0,59 & 0,00 & 0,00 & 0,49 \\
\hline $\operatorname{cg} 2-\operatorname{cg} 3$ & 30 & 0,04 & 0,06 & 0,49 & 0,00 & 0,00 & 0,84 & 0,00 & 0,00 & 0,41 & 0,00 & 0,00 & 0,13 & 0,00 & 0,00 & 0,62 \\
\hline $\operatorname{cg} 2-\operatorname{cg} 4$ & 30 & 0,02 & 0,06 & 0,79 & 0,00 & 0,00 & 0,84 & 0,00 & 0,00 & 0,44 & 0,00 & 0,00 & 0,10 & 0,00 & 0,00 & 0,49 \\
\hline $\operatorname{cg} 2-\operatorname{cg} 5$ & 30 & 0,10 & 0,06 & 0,11 & 0,00 & 0,00 & 0,56 & 0,00 & 0,00 & 0,88 & 0,00 & 0,00 & 0,84 & 0,00 & 0,00 & 0,99 \\
\hline $\operatorname{cg} 3-\operatorname{cg} 4$ & 30 & $-0,03$ & 0,06 & 0,67 & 0,00 & 0,00 & 0,69 & 0,00 & 0,00 & 0,95 & 0,00 & 0,00 & 0,89 & 0,00 & 0,00 & 0,24 \\
\hline $\operatorname{cg} 3-\operatorname{cg} 5$ & 30 & 0,06 & 0,06 & 0,35 & 0,00 & 0,00 & 0,44 & 0,00 & 0,00 & 0,50 & 0,00 & 0,00 & 0,19 & 0,00 & 0,00 & 0,63 \\
\hline $\operatorname{cg} 4-\operatorname{cg} 5$ & 30 & 0,09 & 0,06 & 0,17 & 0,00 & 0,00 & 0,70 & 0,00 & 0,00 & 0,53 & 0,00 & 0,00 & 0,15 & 0,00 & 0,00 & 0,48 \\
\hline
\end{tabular}


Tabela 38. Estimativas dos coeficientes da regressão polinomial: intercepto (a), linear (b) e quadrática (c) para os diferentes genótipos (efeito de doses) para os parâmetros rendimento $(\mathrm{R}, \mathrm{kg} / \mathrm{ha})$, massa de 1000 grãos $\left(\mathrm{M}_{1000}, \mathrm{~g}\right)$, leitura do clorofilômetro (leitura $\mathrm{SPAD}, \mathrm{Lc})$, índice de área foliar (IAF, $\mathrm{m}^{2} / \mathrm{m}^{2}$ ) no florescimento e índice de severidade (IS) à $P$. maydis. Experimento 4.

\begin{tabular}{|c|c|c|c|c|c|c|c|c|c|c|c|c|c|c|c|c|}
\hline \multirow{2}{*}{$\mathrm{P}^{1}$} & \multirow{2}{*}{$\mathrm{GL}^{2}$} & \multicolumn{3}{|c|}{$\mathrm{R}$} & \multicolumn{3}{|c|}{$\mathrm{M}_{1000}$} & \multicolumn{3}{|c|}{$\mathrm{Lc}$} & \multicolumn{3}{|c|}{ IAF } & \multicolumn{3}{|c|}{ IS } \\
\hline & & $\mathrm{Est}^{3}$ & $\mathrm{~S}^{*}$ & $\operatorname{Pr}^{4}$ & Estim. & $\mathrm{s}$ & $\operatorname{Pr}$ & Estim. & $\mathrm{S}$ & $\operatorname{Pr}$ & Estim. & $\mathrm{s}$ & $\operatorname{Pr}$ & Estim. & $\mathrm{s}$ & $\mathrm{Pr}$ \\
\hline a-g1 & 30 & 3374,21 & 433,76 & $<0,01$ & 163,25 & 10,38 & $<0,01$ & 17,93 & 1,97 & $<0,01$ & 2,37 & 0,22 & $<0,01$ & 6,57 & 0,22 & $<0,01$ \\
\hline a-g2 & 30 & 4842,09 & 433,76 & $<0,01$ & 244,43 & 10,38 & $<0,01$ & 30,85 & 1,97 & $<0,01$ & 2,75 & 0,22 & $<0,01$ & 2,76 & 0,22 & $<0,01$ \\
\hline$a-g 3$ & 30 & 4193,83 & 433,76 & $<0,01$ & 204,94 & 10,38 & $<0,01$ & 27,54 & 1,97 & $<0,01$ & 2,19 & 0,22 & $<0,01$ & 1,59 & 0,22 & $<0,01$ \\
\hline a-g4 & 30 & 4567,42 & 433,76 & $<0,01$ & 244,92 & 10,38 & $<0,01$ & 23,64 & 1,97 & $<0,01$ & 2,30 & 0,22 & $<0,01$ & 1,55 & 0,22 & $<0,01$ \\
\hline a-g5 & 30 & 2823,28 & 433,76 & $<0,01$ & 144,44 & 10,38 & $<0,01$ & 13,09 & 1,97 & $<0,01$ & 2,01 & 0,22 & $<0,01$ & 2,50 & 0,22 & $<0,01$ \\
\hline b-g1 & 30 & 28,28 & 8,56 & $<0,01$ & 0,46 & 0,20 & 0,03 & 0,05 & 0,04 & 0,18 & 0,01 & 0,00 & $<0,01$ & 0,02 & 0,00 & $<0,01$ \\
\hline b-g2 & 30 & 21,37 & 8,56 & 0,02 & 0,64 & 0,20 & $<0,01$ & 0,08 & 0,04 & 0,05 & 0,01 & 0,00 & 0,01 & 0,01 & 0,00 & 0,23 \\
\hline b-g3 & 30 & 37,40 & 8,56 & $<0,01$ & 0,33 & 0,20 & 0,11 & 0,08 & 0,04 & 0,05 & 0,02 & 0,00 & $<0,01$ & 0,01 & 0,00 & 0,18 \\
\hline b-g4 & 30 & 25,75 & 8,56 & 0,01 & 0,16 & 0,20 & 0,43 & 0,13 & 0,04 & $<0,01$ & 0,02 & 0,00 & $<0,01$ & 0,01 & 0,00 & 0,16 \\
\hline b-g5 & 30 & 32,38 & 8,56 & $<0,01$ & 0,59 & 0,20 & 0,01 & 0,15 & 0,04 & $<0,01$ & 0,02 & 0,00 & $<0,01$ & 0,01 & 0,00 & 0,07 \\
\hline c-g1 & 30 & $-0,07$ & 0,03 & 0,04 & 0,00 & 0,00 & 0,07 & 0,00 & 0,00 & 0,74 & 0,00 & 0,00 & 0,04 & 0,00 & 0,00 & 0,01 \\
\hline c-g2 & 30 & $-0,06$ & 0,03 & 0,08 & 0,00 & 0,00 & 0,01 & 0,00 & 0,00 & 0,62 & 0,00 & 0,00 & 0,10 & 0,00 & 0,00 & 0,15 \\
\hline c-g3 & 30 & $-0,10$ & 0,03 & 0,01 & 0,00 & 0,00 & 0,28 & 0,00 & 0,00 & 0,79 & 0,00 & 0,00 & $<0,01$ & 0,00 & 0,00 & 0,14 \\
\hline c-g4 & 30 & $-0,06$ & 0,03 & 0,11 & 0,00 & 0,00 & 0,75 & 0,00 & 0,00 & 0,43 & 0,00 & 0,00 & 0,02 & 0,00 & 0,00 & 0,29 \\
\hline c-g5 & 30 & $-0,08$ & 0,03 & 0,02 & 0,00 & 0,00 & 0,03 & 0,00 & 0,00 & 0,22 & 0,00 & 0,00 & $<0,01$ & 0,00 & 0,00 & 0,65 \\
\hline
\end{tabular}

1 P: Parâmetro do coeficiente do modelo.

2 GL: Graus de libaerdade

3 Est: Estimativa dos coeficientes (a: intercepto; b: linear; c: quadrático).

4 Pr: Probabilidade a nível de $5 \%$

* Desvio padrão. 
Tabela 39. Estimativas dos coeficientes da regressão polinomial: intercepto (a), linear (b) e quadrática (c) para comparação entre os diferentes genótipos dos parâmetros rendimento $(\mathrm{R}, \mathrm{kg} / \mathrm{ha})$, massa de 1000 grãos $\left(\mathrm{M}_{1000}, \mathrm{~g}\right)$, leitura do clorofilômetro (leitura $\mathrm{SPAD}, \mathrm{Lc})$, índice de área foliar (IAF, $\mathrm{m}^{2} / \mathrm{m}^{2}$ ) no florescimento e índice de severidade (IS) à P. maydis. Experimento 4

\begin{tabular}{|c|c|c|c|c|c|c|c|c|c|c|c|c|c|c|c|c|}
\hline \multirow{2}{*}{$\mathrm{P}^{1}$} & \multirow{2}{*}{$\mathrm{GL}^{2}$} & \multicolumn{3}{|c|}{$\mathrm{R}$} & \multicolumn{3}{|c|}{$\mathrm{M}_{1000}$} & \multicolumn{3}{|c|}{$\mathrm{Lc}$} & \multicolumn{3}{|c|}{ IAF } & \multicolumn{3}{|c|}{ IS } \\
\hline & & $\mathrm{Est}^{3}$ & $\mathrm{~s}^{*}$ & $\operatorname{Pr}^{4}$ & Estim. & $\mathrm{S}$ & $\operatorname{Pr}$ & Estim. & $\mathrm{S}$ & $\operatorname{Pr}$ & Estim. & $\mathrm{s}$ & $\operatorname{Pr}$ & Estim. & $\mathrm{s}$ & $\operatorname{Pr}$ \\
\hline ag1-ag2 & 30 & $-1467,88$ & 613,43 & 0,02 & $-81,18$ & 14,67 & $<0,01$ & $-12,92$ & 2,78 & $<0,01$ & $-0,38$ & 0,31 & 0,23 & 3,82 & 0,31 & $<0,01$ \\
\hline ag1-ag3 & 30 & $-819,62$ & 613,43 & 0,19 & $-41,69$ & 14,67 & 0,01 & $-9,61$ & 2,78 & $<0,01$ & 0,18 & 0,31 & 0,56 & 4,99 & 0,31 & $<0,01$ \\
\hline ag1-ag4 & 30 & $-1193,21$ & 613,43 & 0,06 & $-81,67$ & 14,67 & $<0,01$ & $-5,72$ & 2,78 & 0,05 & 0,07 & 0,31 & 0,81 & 5,02 & 0,31 & $<0,01$ \\
\hline ag1-ag5 & 30 & 550,93 & 613,43 & 0,38 & 18,82 & 14,67 & 0,21 & 4,84 & 2,78 & 0,09 & 0,36 & 0,31 & 0,26 & 4,07 & 0,31 & $<0,01$ \\
\hline ag2-ag3 & 30 & 648,26 & 613,43 & 0,30 & 39,50 & 14,67 & 0,01 & 3,31 & 2,78 & 0,24 & 0,56 & 0,31 & 0,08 & 1,17 & 0,31 & $<0,01$ \\
\hline ag2-ag4 & 30 & 274,67 & 613,43 & 0,66 & $-0,48$ & 14,67 & 0,97 & 7,21 & 2,78 & 0,01 & 0,45 & 0,31 & 0,16 & 1,21 & 0,31 & $<0,01$ \\
\hline ag2-ag5 & 30 & 2018,81 & 613,43 & $<0,01$ & 100,00 & 14,67 & $<0,01$ & 17,76 & 2,78 & $<0,01$ & 0,74 & 0,31 & 0,02 & 0,26 & 0,31 & 0,42 \\
\hline ag3-ag4 & 30 & $-373,59$ & 613,43 & 0,55 & $-39,98$ & 14,67 & 0,01 & 3,90 & 2,78 & 0,17 & $-0,11$ & 0,31 & 0,73 & 0,03 & 0,31 & 0,91 \\
\hline ag3-ag5 & 30 & 1370,55 & 613,43 & 0,03 & 60,50 & 14,67 & $<0,01$ & 14,46 & 2,78 & $<0,01$ & 0,18 & 0,31 & 0,57 & $-0,92$ & 0,31 & 0,01 \\
\hline ag4-ag5 & 30 & 1744,14 & 613,43 & 0,01 & 100,48 & 14,67 & $<0,01$ & 10,56 & 2,78 & $<0,01$ & 0,29 & 0,31 & 0,36 & $-0,95$ & 0,31 & $<0,01$ \\
\hline bg1-bg2 & 30 & 6,91 & 12,11 & 0,57 & $-0,18$ & 0,29 & 0,55 & $-0,03$ & 0,05 & 0,65 & 0,00 & 0,01 & 0,68 & 0,01 & 0,01 & 0,05 \\
\hline bg1-bg3 & 30 & $-9,12$ & 12,11 & 0,46 & 0,13 & 0,29 & 0,66 & $-0,02$ & 0,05 & 0,65 & $-0,01$ & 0,01 & 0,15 & 0,01 & 0,01 & 0,06 \\
\hline bg1-bg4 & 30 & 2,53 & 12,11 & 0,84 & 0,30 & 0,29 & 0,31 & $-0,07$ & 0,05 & 0,19 & 0,00 & 0,01 & 0,53 & 0,01 & 0,01 & 0,06 \\
\hline bg1-bg5 & 30 & $-4,09$ & 12,11 & 0,74 & $-0,13$ & 0,29 & 0,65 & $-0,09$ & 0,05 & 0,11 & $-0,01$ & 0,01 & 0,26 & 0,01 & 0,01 & 0,12 \\
\hline bg2-bg3 & 30 & $-16,03$ & 12,11 & 0,20 & 0,30 & 0,29 & 0,30 & 0,00 & 0,05 & 0,99 & $-0,01$ & 0,01 & 0,07 & 0,00 & 0,01 & 0,93 \\
\hline bg2-bg4 & 30 & $-4,38$ & 12,11 & 0,72 & 0,48 & 0,29 & 0,11 & $-0,05$ & 0,05 & 0,38 & $-0,01$ & 0,01 & 0,30 & 0,00 & 0,01 & 0,89 \\
\hline bg2-bg5 & 30 & $-11,01$ & 12,11 & 0,37 & 0,04 & 0,29 & 0,88 & $-0,07$ & 0,05 & 0,24 & $-0,01$ & 0,01 & 0,13 & 0,00 & 0,01 & 0,64 \\
\hline bg3-bg4 & 30 & 11,65 & 12,11 & 0,34 & 0,17 & 0,29 & 0,56 & $-0,05$ & 0,05 & 0,38 & 0,01 & 0,01 & 0,41 & 0,00 & 0,01 & 0,96 \\
\hline bg3-bg5 & 30 & 5,03 & 12,11 & 0,68 & $-0,26$ & 0,29 & 0,38 & $-0,07$ & 0,05 & 0,23 & 0,00 & 0,01 & 0,74 & 0,00 & 0,01 & 0,71 \\
\hline bg4-bg5 & 30 & $-6,63$ & 12,11 & 0,59 & $-0,43$ & 0,29 & 0,15 & $-0,02$ & 0,05 & 0,75 & 0,00 & 0,01 & 0,61 & 0,00 & 0,01 & 0,75 \\
\hline $\operatorname{cg} 1-\operatorname{cg} 2$ & 30 & $-0,01$ & 0,05 & 0,83 & 0,00 & 0,00 & 0,52 & 0,00 & 0,00 & 0,56 & 0,00 & 0,00 & 0,76 & 0,00 & 0,00 & 0,38 \\
\hline $\operatorname{cg} 1-\operatorname{cg} 3$ & 30 & 0,03 & 0,05 & 0,60 & 0,00 & 0,00 & 0,57 & 0,00 & 0,00 & 0,67 & 0,00 & 0,00 & 0,16 & 0,00 & 0,00 & 0,39 \\
\hline $\operatorname{cg} 1-\operatorname{cg} 4$ & 30 & $-0,02$ & 0,05 & 0,74 & 0,00 & 0,00 & 0,27 & 0,00 & 0,00 & 0,43 & 0,00 & 0,00 & 0,76 & 0,00 & 0,00 & 0,25 \\
\hline $\operatorname{cg} 1-\operatorname{cg} 5$ & 30 & 0,01 & 0,05 & 0,81 & 0,00 & 0,00 & 0,80 & 0,00 & 0,00 & 0,27 & 0,00 & 0,00 & 0,43 & 0,00 & 0,00 & 0,11 \\
\hline $\operatorname{cg} 2-\operatorname{cg} 3$ & 30 & 0,04 & 0,05 & 0,46 & 0,00 & 0,00 & 0,23 & 0,00 & 0,00 & 0,87 & 0,00 & 0,00 & 0,09 & 0,00 & 0,00 & 0,98 \\
\hline $\operatorname{cg} 2-\operatorname{cg} 4$ & 30 & $-0,01$ & 0,05 & 0,90 & 0,00 & 0,00 & 0,08 & 0,00 & 0,00 & 0,84 & 0,00 & 0,00 & 0,54 & 0,00 & 0,00 & 0,77 \\
\hline $\operatorname{cg} 2-\operatorname{cg} 5$ & 30 & 0,02 & 0,05 & 0,65 & 0,00 & 0,00 & 0,69 & 0,00 & 0,00 & 0,60 & 0,00 & 0,00 & 0,28 & 0,00 & 0,00 & 0,47 \\
\hline $\operatorname{cg} 3-\operatorname{cg} 4$ & 30 & $-0,04$ & 0,05 & 0,39 & 0,00 & 0,00 & 0,59 & 0,00 & 0,00 & 0,71 & 0,00 & 0,00 & 0,27 & 0,00 & 0,00 & 0,75 \\
\hline $\operatorname{cg} 3-\operatorname{cg} 5$ & 30 & $-0,01$ & 0,05 & 0,77 & 0,00 & 0,00 & 0,41 & 0,00 & 0,00 & 0,49 & 0,00 & 0,00 & 0,53 & 0,00 & 0,00 & 0,45 \\
\hline $\operatorname{cg} 4-\operatorname{cg} 5$ & 30 & 0,03 & 0,05 & 0,57 & 0,00 & 0,00 & 0,18 & 0,00 & 0,00 & 0,75 & 0,00 & 0,00 & 0,63 & 0,00 & 0,00 & 0,66 \\
\hline
\end{tabular}




\section{REFERÊNCIAS BIBLIOGRÁFICAS}

ALFONSI, R.R. Agrometeorologia: importância e aplicações. Piracicaba: ESALQ, 1991.23p.

ANDRADE, F.H. Analysis of growth and yield of mayze, sunflower and soybean grown at Balcarce. Argentina. Field Crops Research, v.41, p.1-12, 1995.

ANDRADE, F.H.; UHART, S.; ARGUISSAIN, G. Rendimento potencial del maiz en Balcarce: analisis de los fatores que lo determinan. Barcelona: Instituto Nacional de Tecnologia Agropecuária, 1991. 11p. (Boletin Técnico, 101).

ARGENTA， G.; SILVA， P.R.F.; BORTOLINI， C.G.; STRIEDER， M.L.; FORSTHOFER, E.L. Monitoramento do nível de nitrogênio na planta de milho através do teor de clorofila avaliado pelo clorofilômetro. In: CONGRESSO NACIONAL DE MILHO E SORGO, 23. Uberlândia, 2000. Anais. Uberlândia: ABMS, 2000, p.128

ARNON, I. Mineral nutrition of maize. Bern: International Potash Institute, 1975. $452 \mathrm{p}$.

BALKO, L.G.; RUSSELL, W.A. Response of maize inbred kines to $\mathrm{N}$ fertilizer. Agronomy Journal, v. 72, n.5, p.723-732, 1980.

BATAGLIA, O.C.; QUAGGIO, J.A., BRUNINI, O.; CIARELLI, D.M. Adubação nitrogenada e ajustamento osmótico em milho e sorgo. Pesquisa Agropecuária Brasileira, v.20, n.6, p.659-665, jun. 1985.

BERGER, J. Maize production and the manuring of maizes. Zurich: Gonzelt \& Herber, 1962. p.38-41. 
BERLATO, M.A.; SUTILI, V.R. Determinação das temperaturas base dos subperíodos emergência-despendoamento e emergência-espigamento de 3 cultivares de milho. In: REUNiÃO TÉCNICA DE MILHO E SORGO, 23., Porto Alegre, 1976. Resumos. Porto Alegre: Agropecuária, 1976. p.26.

BORÉM, A. Interação genótipo $\mathrm{x}$ ambiente. In: BORÉM, A. Melhoramento de plantas. Viçosa: UFV, 1997. p.123-133.

BRASIL. Ministério da Agricultura. Secretaria Nacional de Defesa Agropecuária. Regras para análises de sementes. Brasília, 1992. 365p.

BRASIL, E.M.; CARVALHO, Y. de. Comportamento de híbridos de milho em relação a Phaeosphaeria maydis em diferentes épocas de plantio. Pesquisa Agropecuária Brasileira, v.33, n.12, p.1977-1981, dez. 1998.

BULL, L.T. Nutrição mineral do milho. In: BULL, L.T.; CANTARELLA, H. Cultura do milho: fatores que afetam a produtividade. Piracicaba: POTAFOS, 1993. p.73-79. CRAWFORD, T.W.; RENDG, V.V.; BROADBENT, F.E. Sources, fluxes, and sinks of nitrogen during early reproductive growth of maize (Zea mays L.). Plant Physiology, v. 70, n.1, p.654-660, 1982.

CHAVES, L.J. Interação de genótipos com ambientes. In: Recursos genéticos e melhoramento: Plantas. NASS, L.L; VALOIS, A.C.C.; MELO, I..S.; VALADARES-INGLIS, M.C. Rondonópolis: Fundação MT, 2001. p.673-713.

DOURADO-NETO, D. Modelos fitotécnicos referentes à cultura de milho. Piracicaba, 1999. 229p. Tese (Livre-Docência) - Escola Superior de Agricultura "Luiz de Queiroz", Universidade de São Paulo.

DUDIENAS, C.; DUARTE, A.P., PATERNIANI, M.E.A.G.Z.; CASTRO, J.L.; GOZI, C.; VASCONCELlOS, J.A.M.; GELLER, C.; PAVÃO, L.A. Severidade da mancha de Phaeosphaeria em cultivares de milho safrinha. In: CONGRESSO PAULISTA DE FITOPATOLOGIA, 21., Botucatu, 1998. Botucatu: UNESP, FCAB, 1998. p.111.

EBELHAR, S.A.; KAMPRATH, E.J.; MOLL, R.H. Effects of nitrogen and potassium on growth and cation composition of corn genotypes differing in average ear number. Agronomy Journal, v.79, n.5, p.875-881, 1987. 
FANCELLI, A.L. Plantas alimentícias: guia para aula, estudo e discussão. Piracicaba: CALQ, 1986. 131p.

FANCELLI, A.L. Influência do desfolhamento no desempenho de plantas e de sementes de milho (Zea mays, L.). Piracicaba, 1988. 172p. Tese (Doutorado) - Escola Superior de Agricultura "Luiz de Queiroz", Universidade de São Paulo.

FANCELLI, A.L. Milho e feijão: elementos para manejo em agricultura irrigada. Piracicaba: ESALQ, Depto. Agricultura, 1994. 14p.

FANCELLI, A.L.; DOURADO-NETO, D. Cultura do milho: aspectos fisiológicos e manejo da água. In: SEMINÁRIO SOBRE FISIOLOGIA DA PRODUÇÃO E MANEJO DE ÁGUA E DE MICRONUTRIENTES NA CULTURA DO MILHO DE ALTA PRODUTIVIDADE, Piracicaba, 1996. Informações Agronômicas. POTAFOS, n. 73, p.1-4, 1996.

FANCELLI, A.L.; DOURADO-NETO, D. Milho: Ecofisiologia e rendimento. Tecnologia da produção de milho. Piracicaba: ESALQ, Departamento de Agricultura, 1997. p.157-168.

FANCELli, A.L.; DOURADO-NETO, D. Produção de milho. Guaíba: Agropecuária, 2000. 387p.

FANTIN, G.M.; DUDIENAS, C.; DUARTE, A.P.; PATERNIANI, M.E.A.G.Z.; BORTOLETTO, N.; CAZENTINI FILHO, G.; CASTRO, J.L; BOLONHEZI, D. Ocorrência e intensidade de doenças em milho no Estado de São Paulo: safra 1995/1996. In: CONGRESSO NACIONAL DE MILHO E SORGO, 23. Uberlândia, 2000. Anais. Uberlândia: ABMS, 2000, p.223.

FAO. Production Yearbook. v.52, p.71, 1998.

FERNANDES, F.T.; OLIVEIRA, E. Milho manchado e milho sem produção. Cultivar, v.1, n.11, p.38-39, dez. 1999.

FERNANDES, F.T.; OLIVEIRA, E. Principais doenças na cultura do milho. Sete Lagoas: Embrapa, CNPMS, 1997. 80p. (Embrapa. CNPMS. Circular Técnica, 26).

FERNANDES, F.T.; SANS, L.M.A. Influência das condições climáticas na ocorrência das lesões foliares por Phaeophaeria maydis. In: CONGRESSO NACIONAL DE MILHO E SORGO, 20., Goiânia, 1994. Resumos. Goiânia: ABMS, 1994. p.136. 
FERRAZ, E. C. Fisiologia do milho. In: INSTITUTO BRASILEIRO DA POTASSA. Cultura e adubação do milho. São Paulo, 1966. p.369-379.

FERREIRA, J. M. Análise genética e síntese de populações visando resistência à ferrugem (Puccinia polysora Underw) em milho (Zea mays). Piracicaba, 1999. 230p. Tese (Doutorado) - Escola Superior de Agricultura “Luiz de Queiroz”, Universidade de São Paulo.

FNP - CONSUltORIA E COMÉRCIO. AGRIANUAL 2000: Anuário da Agricultura Brasileira. São Paulo, Editora Argos Comunicação, 2000. p.436.

FRANCIS, C.A.; RUTGER, J.N.; PALMER, A.F.E. A rapid method for plant leaf area estimation in maize (Zea mays). Crop Science, v.9, p.537-539, 1969.

FRATTINI, J.A. Cultura do milho: instruções sumárias. Campinas: CATI, 1975. 26p. GODOY, C.V.; AMORIM, L.; BERGAMIN FILHO, A. Efeito da mancha de Phaeosphaeria na eficiência fotossintética de plantas de milho. Fitopatologia Brasileira, v.23, supl., p.246, ago.1998a.

GODOY, C.V.; AMORIM, L.; BERGAMIN FILHO, A.; SILVA, W.J.; SOLFERINO, O.B.; SILVA, H.P.; PEREIRA, O.A.P. Avaliação do progresso de doenças em diferentes localidades e épocas de plantio. In: CONGRESSO PAULISTA DE FITOPATOLOGIA, 21., Botucatu, 1998. Botucatu: UNESP, FCA, 1998b. p.117.

PIMENTEL GOMES, F. Curso de estatística experimental. 11. ed. Piracicaba: Nobel, 1985. 466p.

PINTO, N.F.J.de A.; FERNANDES, F.T.; OLIVEIRA, E. Milho (Zea mays L.): Controle de doenças. In: VALE, F.X.R.; ZAMBOLIM, L. (Ed.). Controle de doenças de plantas. Viçosa: UFV, 1997. p. 821-864.

HAWKINS, R.C.; COOPER, P.J.M. Growth, development and grain yield of maize. Experimental Agriculture, v.17, p.203-207, 1981.

KARLEN, D.L.; FLANNERY, R.L.; SADLER, E.J. Aerial accumulation and partitioning of nutrients by corn. Agronomy Journal, v.80, n.2, p.232-242, 1988.

LIMA FILHO, O.F. Resistência a fatores abióticos: desordens nutricionais. In: DESTRO, D.; MONTALVÁN, R. Melhoramento genético de plantas. Londrina: Editora UEL, 1999. p.769-797. 
MAGALHÃES, A.C.N.; SILVA, W.J. Determinantes genético-fisiológicos da produtividade do milho. In: PATERNIANI, E. Melhoramento e produção de milho no Brasil. São Paulo: Fundação Cargill, 1987. p.346-379.

MAGALHÃES, J.V. Absorção e translocação de nitrogênio por plantas de milho (Zea mays, L.) submetidas a períodos crescentes de omissão de fósforo na solução nutritiva. Viçosa, 1996. 76p. Dissertação (Mestrado) - Universidade Federal de Viçosa.

MARQUARD, R.D.; TIPTON, J.L Relationship between extractable chlorophyll and an in situ method to estimate leaf greenness. Horticultural Science, v.22, n.6, p.1327, 1987.

MARSCHNER, H. Mineral nutrition of higher plants. San Diego: Academic Press, 1986. 674p.

MENTEN, J.O.M.; PARADELA, A.L.; MARTINS, L.M.O.; ARANTES, S.R.A. Reação de genótipos de milho à Phaeosphaeria maydis e efeito na produtividade. Ecossistema, v.21, p.72-74, 1996.

MONTEIRO, J.A. Estresse ambiental: considerações econômicas. In: SIMPÓSIO INTERNACIONAL SOBRE ESTRESSE AMBIENTAL: O MILHO EM PERSPECTIVA, Sete Lagoas, 1995. Sete Lagoas: EMBRAPA, CNPMS, 1995. p.1337.

NEPTUNE, A.M.L.; NAKAGAWA, J.; SCOTTON, L.C.; SOUZA, E.A. Efeitos de doses não eqüidistantes de $\mathrm{N}, \mathrm{P}, \mathrm{K}$ nas concentrações destes macronutrientes na folha e na produção do milho (Zea mays). Anais da Escola Superior de Agricultura "Luiz de Queiroz", v.39, p.917-941, 1982.

PACHECO, A.C.; VIEIRA, L.C.; GUIMARÃES, D.R.; CANTON, T. Reação de Híbrido de Milho à mancha foliar de Phaeosphaeria. Agropecuária Catarinense, v.12, n.2, p.14-16, jun.1999.

PACOLA-MEIRELLES, L.D.; PINTO, N.F.J.A.; MAKI, C.S.; SILVA, W.F.M.; VIELMA, E.R.P. Avaliação da expressão de resistência para mancha foliar de Phaeosphaeria em milho (Zea mays L.) quanto ao número e tamanho de lesões. In: CONGRESSO NACIONAL DE MILHO E SORGO, 22., Recife, 1998. Resumos. Recife: ABMS, 1998. p.161. 
PARENTONI, S.N.; FERNANDES, F.T.; GAMA, E.E.G; LOPES, M.A.; EVARISSO, P.E.O.; SANTOS, M.X.; SILVA, A.E. Efeito de níveis de nitrogênio sobre a severidade da doença foliar causada por Phaeosphaeria maydis em milho. In: CONGRESSO NACIONAL DE MILHO E SORGO, 21., Londrina, 1996. Resumos. Londrina: IAPAR, 1996. p.164.

PRESELLO, D. A.; MORATA, M. M. La roya común del maíz, su importancia y manejo. Revista de Tecnologia Agropecuária, v.3, n.8, p.26-47, 1998.

RAMOS, L.R.M.; MUNDSTOCK, C.M. Acúmulo de matéria seca em três híbridos de milho no período de formação dos grãos. Pesquisa Agropecuária Brasileira, v.21, n.3, p.265-270, 1986.

ROSSIELO, R.O.P.; PIMENTEL, C. Entendimentos sobre relações hídricas na cultura do milho In: SIMPÓSIO INTERNACIONAL SOBRE ESTRESSE AMBIENTAL: O MILHO EM PERSPECTIVA, Sete Lagoas, 1995. Anais. Sete Lagoas: EMBRAPA, CNPMS, 1995. p. 131-146.

SILVA, H. P.;MENTEN, J.O.M. Manejo integrado de doenças na cultura do milho. In: FANCELli, A.L.; DOURADO-NETO, D. Tecnologia da produção de milho. Piracicaba: ESALQ, Departamento de Agricultura, 1997. p.40-48.

SMEAL, D.; ZHANG, H. Chlorophyll meter evaluation for nitrogen management in corn. Communications in Soil Science and Plant Analysis, v.25, n.9/10, p.1495-1503, 1994.

VIDAL TORRADO, P.; SPAROVEK, G. Mapa pedológico detalhado do Campus “Luiz de Queiroz”. Piracicaba: ESALQ, 1993. (escala 1:10.000).

VIEIRA JÚNIOR, P.A. Milho (Zea mays). In: CASTRO, P.R.C.; KUGLE, R.A. Ecofisiologia de cultivos anuais. São Paulo: NOBEL, 1999. p.41-68.

VILlA NOVA, N.A.; PEDRO JÚNIOR, M.J.; PEREIRA, A.R.; OMETTO, J.C. Estimativas de graus-dia acumulados acima de qualquer temperatura base, em função das temperaturas máxima e mínima. São Paulo: USP, Instituto de Geografia, 1972. 8p. (Caderno da Ciência da Terra, 30).

YAMADA, T. A nutrição mineral e a resistência das plantas às doenças. Informações Agronômicas POTAFOS, n.72, p.1-3, 1995. 
YAMADA, T. O nitrogênio e o potássio na adubação da cultura do milho. Informações Agronômicas POTAFOS, n.78, p.1-4, 1997.

ZOCCOLI, T.T.; CASELA, C.R.; GUIMARÃES, F.B. Avaliação de genótipos de milho

(Zea mays) quanto a resistência a mancha de Phaeosphaeria. In: CONGRESSO NACIONAL DE MILHO E SORGO, 21. Londrina, 1996. Resumos. Londrina. IAPAR, 1996. p.315. 